\title{
Floating Exchange Rates: Experience and Prospects
}

With THE ABANDONMENT of fixed dollar exchange rates in March 1973, the world's industrialized countries adopted temporarily a system of floating exchange rates that many economists had advocated to permit individual nations to reconcile the often conflicting requirements of internal and external balance. In spite of a surprising short-run volatility in exchange markets under the interim system, the consensus among policymakers at the end of 1975 was that floating rates had worked reasonably well. This consensus found expression in the joint declaration following the November 1975 Rambouillet economic summit, which committed participating monetary authorities to "counter disorderly market conditions, or erratic fluctuations, in exchange rates," but made no provision for a return to fixed parities. Agreements at Rambouillet led directly to the formalization of the floating rate system through amendment of the Articles of Agreement of the International Monetary Fund (IMF) at Kingston, Jamaica, in January 1976. A new Article IV dealing with exchange rate arrangements implicitly sanctioned floating, subject only to broad prohibitions against actions detrimental to "financial and economic stability.",

The sharp real depreciation of the dollar between 1976 and 1979 and the even larger real appreciation between 1979 and 1985 have led many

During the preparation of this paper I received helpful suggestions from Robert Cumby, Arnold Kling, Bonnie Loopesko, Richard Marston, Frederic Mishkin, Kenneth Rogoff, René Stulz, and members of the Brookings Panel. Michael Klein provided research assistance and discussion. Financial support from the National Science Foundation and the Alfred P. Sloan Foundation is acknowledged with thanks.

1. These events are described in greater detail in Robert Solomon, The International Monetary System, 1945-1981 (Harper and Row, 1982). 
to modify whatever sanguine views of the floating rate system they may have held in the mid-1970s. Labeled misalignments, these massive medium-term swings in floating rates are increasingly viewed as a source of resource misallocation, a spur to protectionism, and an impediment to prompt current account adjustment. Some contend that the drastic real exchange rate movements of recent years have resulted from speculative pressures related only tangentially, if at all, to the course of monetary policies or to developments on the real sides of the industrialized economies.

Proposals to reform the present international payments system are receiving renewed attention in government and academic circles. Recently, at a meeting in Tokyo, representatives of the IMF's Group of Ten rejected greater fixity of exchange rates and affirmed that "the key elements of the current international monetary system require no major institutional change."'2 Later, in September of this year, officials from the Group of Ten agreed to a policy of concerted intervention to lower the exchange value of the dollar. The debate over floating exchange rates is certain to continue.

This paper reviews the performance of floating rates over the decade since the Jamaica revision of the IMF Articles of Agreement and asks whether a less flexible exchange rate system could have done better. ${ }^{3}$ My discussion of alternatives to the present system concentrates on fixed exchange rates, but an extension of the arguments to hybrid systems involving flexible target zones is straightforward. The main issues that arise in comparing fixed and flexible rates and the main conclusions I draw on these issues are as follows.

2. See "Report of the Deputies: The Functioning of the International Monetary System,', IMF Survey, Supplement on the Group of Ten Deputies' Report (July 1985), pp. $2-14$.

3. For complementary assessments of the floating rate experience, see Jacques R. Artus and John H. Young, "Fixed and Flexible Exchange Rates: A Renewal of the Debate," International Monetary Fund Staff Papers, vol. 26 (December 1979), pp. 65498; Richard N. Cooper, "Flexible Exchange Rates, 1973-1980: How Bad Have They Really Been?' in Richard N. Cooper and others, eds., The International Monetary System under Flexible Exchange Rates: Global, Regional, and National (Ballinger, 1982), pp. 316; Morris Goldstein, "The Exchange Rate System: Lessons of the Past and Options for the Future," Occasional Paper 30 (International Monetary Fund, July 1984); and John Williamson, The Exchange Rate System, Policy Analyses in International Economics 5 (Institute for International Economics, September 1983). 
EXCHANGE RATE TARGETS AND MONETARY CONTROL

Proposals to limit nominal exchange rate flexibility would in practice tie national monetary policies to the task of exchange rate stabilization. The room for domestic monetary maneuver that remained would depend on the stringency of the new exchange rate commitments, while the international distribution of control over the world money supply would depend on the mechanism in place for official settlement of payments imbalances. In the absence of capital controls, a resurrection of the system that broke down in 1973 would substantially deprive central banks other than the reserve-currency issuer of monetary autonomy. No central bank in any nation except the United States would have the ability to influence domestic monetary conditions through unaided monetary policy. Only through recurring parity changes would other countries be able to avoid accepting the trend world inflation rate set by the reserve center.

\section{EXCHANGE RATE REGIMES AS AUTOMATIC STABILIZERS}

The exchange rate regime affects the variability of output and price levels in response to disturbances that policymakers are unable to observe directly. A potentially stabilizing role of the exchange rate is another reason why a loss of monetary autonomy through exchange rate targeting might have costly macroeconomic consequences for individual countries. Fixed exchange rates can be better automatic stabilizers than are floating rates when most shocks originate in asset markets; but when goods-market shifts drive macroeconomic fluctuations, floating rates generally have an advantage. And the evidence is that many disturbances of the early 1980s originated in goods markets. The stability advantages of floating rates in these circumstances, however, will be distributed unevenly among the economy's sectors. This misallocation is the root of the misalignment problem.

\section{EXCHANGE RATE REGIMES AND AUTOMATIC DISCIPLINE}

No international monetary system likely to be put into place seems clearly preferable to the current one in terms of the automatic discipline 
it imposes in discouraging one country from embarking on policy courses harmful to others. A regime of fixed exchange rates probably would not have prevented the recent U.S. fiscal surge that is at the center of the current international adjustment problem. Nor, given U.S. fiscal policy, would fixed rates have prevented a substantial real dollar appreciation from emerging over a longer period.

\section{THE VOLATILITY OF FLOATING RATES AND THE CREDIBILITY} OF FIXED RATES

Exchange rate volatility in the short term is widely viewed as a drawback of floating rates. Fixed rates, however, are also subject to change without notice, and when parity changes offer immediate macroeconomic benefits, authorities will be tempted to alter rates. An evaluation of the relative merits of exchange rate regimes, therefore, must recognize that the only realistic fixed rate regime is one in which the exchange rate is not always credibly fixed. There is little direct evidence that short-term exchange rate volatility has been harmful. Capital account volatility under unconvincingly fixed rates, however, might entail serious costs. Further, the possibility of surprise exchange rate changes negates most of the "disciplinary" advantages of a credibly fixed rate or zone.

The conclusion I reach is broadly similar to that reached by the Group of Ten deputies. Despite flaws in the present system, it would be neither feasible nor clearly desirable for the European Currency Unit and the Japanese yen to be pegged to the dollar. Cycles in real exchange rates have proved to be one of the most costly aspects of floating rates, but they have at times been a symptom of inappropriate national policies rather than an independent cause of distress. In particular, I argue that the most recent episode of U.S. dollar misalignment is in large part due to macroeconomic policies, both in the United States and abroad, that a fixed rate regime would have been unable to prevent and possibly unable to survive without the imposition of costly capital controls.

\section{PLAN OF THE PAPER}

The balance of the paper is divided into six sections and a conclusion. The first section, a review of recent macroeconomic developments in 
the major industrial countries, emphasizes the uneven nature of the world recovery from the $1980-82$ recession. It also notes differences in the connection between the real exchange rate and the level of manufacturing employment in different countries and periods. The next section develops a model of the international transmission of macroeconomic disturbances under floating and fixed exchange rates. The model is a useful framework for the review, in the third section, of the theory of optimum currency areas. The theory, which observes that there may be costs as well as benefits in expanding the size of regions where exchange rates are fixed, is a useful starting point for evaluating floating and fixed rates.

The fourth section examines the policy shifts, both in the United States and abroad, underlying the large swings in the U.S. dollar's real exchange rate since 1976. It also investigates the role that shocks to goods markets have played in exchange rate determination. In light of the evidence presented in this section on the sources of disturbances, the next section looks into the question of whether a regime of fixed rates would have been preferable since 1976. The final section of the paper weighs the problem of the short-term volatility of floating exchange rates against the problems that may arise when the exchange rate is unconvincingly fixed.

\section{Exchange Rate Experience and the Current Adjustment Problem}

The recent appreciation of the dollar, both in real and in nominal terms, is the latest and most dramatic movement in a series of ups and downs initiated by the exchange rate realignments of 1971-73. This section reviews the medium-term swings in the dollar's real external value since the closing years of the fixed rate system. These persistent medium-term swings in real exchange rates are often identified as a major cost of the current floating rate system.

Because such swings in real exchange rates may alter the allocation of resources between sectors of the economy producing tradable and nontradable goods, I also examine the evolution of employment during this period in the manufacturing sectors of the United States, Germany, and Japan. While manufactures compose only a subset of tradables, the evidence presented illustrates possible correlations between real ex- 
change rate movements and the economy's output mix. The data also reflect important trends in the industrial structure of the United States. ${ }^{4}$

I will argue in a later section that the current alignment of industrialized country exchange rates is in part a consequence of differing fiscal stances and the uneven nature of the recovery from the worldwide recession of 1980-82. The section concludes with a review of the international pattern of demand growth since 1982 and the associated current account positions.

THE DOLLAR'S REAL EXCHANGE RATE IN HISTORICAL

PERSPECTIVE

Figure 1 shows the evolution since 1967 of two measures of the dollar's real value in terms of foreign currencies. The first of these, the International Monetary Fund's measure of cyclically normalized relative unit labor costs in manufacturing, is the IMF's preferred indicator of international competitiveness. The second measure shown in figure 1 is based on wholesale prices. U.S. prices appear in the numerator of each measure, while the denominator is a trade-weighted average of foreign prices multiplied by nominal dollar exchange rates. A rise in either of these indexes of the dollar's real external value-a real appreciationrepresents an increase in U.S. prices relative to an average of the dollar prices of foreign labor or manufactures. ${ }^{5}$

Both measures show a steep real depreciation of the dollar between 1969 and 1975, relatively little change between 1973 and 1976, another real depreciation between 1976 and 1979, and, finally, the massive real appreciation that continued without prolonged interruption from 1979 until early 1985. (Since February 1985, the dollar has depreciated sharply.) The annual data plotted in figure 1 illustrate a real appreciation between 1979 and 1984 on the order of 40 percent. The magnitude of this change is unprecedented since the abandonment of fixed parities, and it

4. For a detailed discussion of these trends, see Robert Z. Lawrence, "Is Trade Deindustrializing America? A Medium-Term Perspective," BPEA, 1:1983, pp. 129-61.

5. For an evaluation of the alternative measures, see Jacques Artus and Malcolm D. Knight, "Issues in the Assessment of the Exchange Rates of Industrial Countries," Occasional Paper 29 (International Monetary Fund, July 1984). The IMF assigns weights to foreign prices according to a foreign country's importance as a trading partner and its importance as a competitor in third markets. 
Figure 1. Measures of the Dollar's Real Effective Foreign Exchange Value, 1967-85 ${ }^{\text {a }}$

Index, $1980=100$

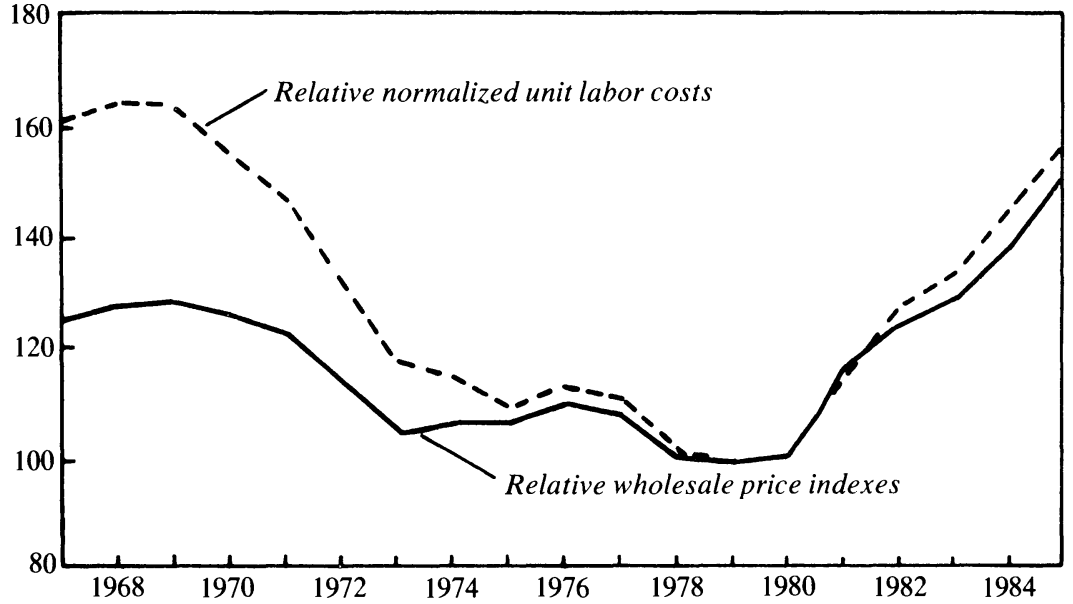

Source: International Monetary Fund, International Financial Statistics.

a. Annual data for 1967-84; first quarter data for 1985. Real exchange rates are U.S. wholesale prices or cyclically normalized unit labor costs, divided by the U.S. dollar equivalents of foreign wholesale prices or labor costs. A rise in either index is a real appreciation of the U.S. dollar against foreign currencies.

has naturally sparked concern about the performance of the current exchange rate system.

Bilateral comparisons of U.S. wholesale prices against exchange rate adjusted wholesale prices in Germany and Japan are shown in figure 2. These bilateral measures are broadly in line with the multilateral measures graphed in figure 1, but there are differences in the timing and magnitudes of changes. The increase in the dollar's real value in terms of the deutsche mark between 1979 and 1984 is roughly 60 percent. The corresponding figure for the yen is only 20 percent, a reflection of the yen's relatively greater strength against the dollar in recent years. Considerable variance in the evolution of U.S. competitiveness vis-àvis individual trading partners underlies the average measures shown in the first figure.

One immediate implication of the evidence is that nominal exchange rates have not conformed well to the purchasing power parity (PPP) theory over the floating rate period.$^{6}$ The failure of PPP is particularly

6. This fact is documented for a number of bilateral exchange rates in Jacob A. Frenkel, "The Collapse of Purchasing Power Parities during the 1970s," European Economic Review, vol. 16 (May 1981), pp. 145-65. 
Figure 2. Bilateral Real Exchange Rates between the United States and Germany and between the United States and Japan, 1970-85

Index, $1980=100$

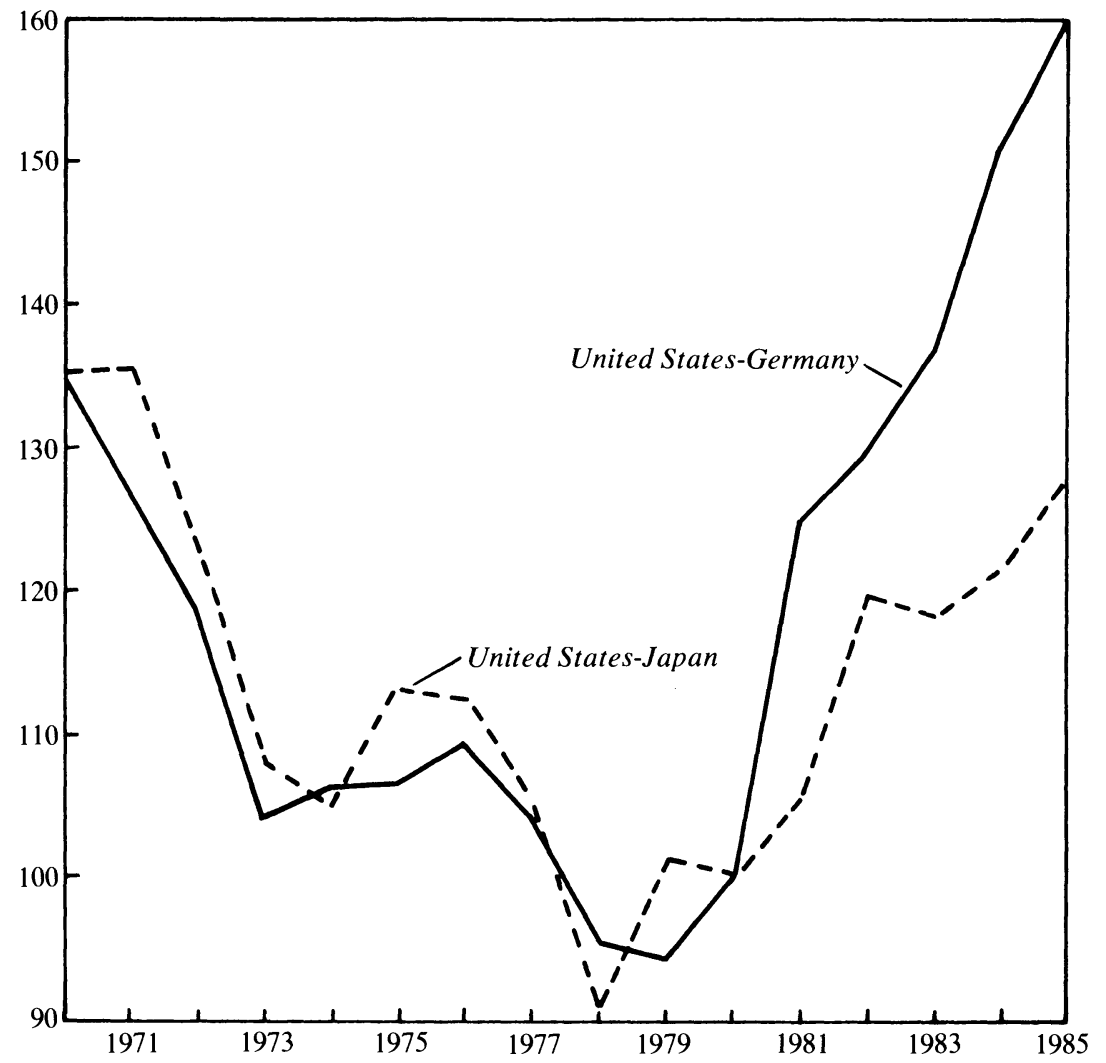

Source: Organization for Economic Cooperation and Development, Main Economic Indicators.

a. Data for 1985 are the March values. The values plotted between 1970 and 1984 are year averages of monthly bilateral real exchange rates, calculated as the U.S. wholesale price index divided by the dollar value of the foreign wholesale price index. A rise in either bilateral rate is a real appreciation of the U.S. dollar against the other currency.

striking when one notes the large swings in the measures based on wholesale price indexes, which are dominated by tradable manufactures that are rather similar across countries. Strict forms of the PPP doctrine predict that the exchange rate will exactly offset intercountry differentials in consumer price inflation or even wage inflation. Weaker forms assert that exchange rates adjust to offset inflation differentials between countries' tradable goods sectors. No version of PPP appears to be a good characterization of the data shown above. It is true that the dollar- 
yen real exchange rate, measured on the basis of wholesale price indexes (WPIs), stood at the same level in 1984 as in 1972. But in view of the large and persistent fluctuations in between, this fact can hardly be regarded as more than a coincidence. ${ }^{7}$

An important empirical regularity related to this failure of PPP is the close correlation between changes in real exchange rates and changes in nominal exchange rates. Strict purchasing power parity theory implies that changes in nominal exchange rates are not associated with changes in real exchange rates. But as figure 3 illustrates, from January 1976 to April 1985, the correlation between monthly percentage changes in the real and nominal effective dollar exchange rate indexes (as measured by Morgan Guaranty Trust Company of New York) is $0.95 .^{8}$ The corresponding correlation coefficients for the Morgan deutsche mark and yen indexes are 0.96 and 0.98 , respectively. Several possible theoretical explanations for these high correlations are discussed in the next section.

It is noteworthy that the floating rate era was ushered in by a real depreciation of the dollar comparable in magnitude to the latest real appreciation. As figure 1 shows, that real depreciation began in 1969. Steep when measured in terms of wholesale prices, it is even steeper when the measure is based on labor costs. The reason for the difference is the well-documented acceleration of real wage growth abroad at the end of the 1960s.

The events leading to this real depreciation are worth recalling, as they provide a useful counterpoint to recent charges that floating exchange rates foster persistent exchange rate misalignment. In May 1971, weakness in the U.S. trade balance and balance of payments

7. For accounts of the purchasing power parity doctrine, see Jacob A. Frenkel, "Purchasing Power Parity: Doctrinal Perspectives and Evidence from the 1920s, " Journal of International Economics, vol. 6 (May 1978), pp. 169-91; Irving B. Kravis and Robert E. Lipsey, "Toward an Explanation of National Price Levels," Princeton Studies in International Finance 52 (Princeton University, International Finance Section, November 1983); and Rudiger Dornbusch, "Purchasing Power Parity," Working Paper 1591 (National Bureau of Economic Research, March 1985).

8. Once again, a rise in one of these measures is a real or nominal effective appreciation of the dollar, while a fall is a depreciation. The Morgan Guaranty Trust nominal effective exchange rate indexes use 1980 bilateral trade weights for trade in manufactures among fifteen industrial countries. The real effective exchange rate indexes adjust the nominal indexes for differential U.S.-foreign inflation in the wholesale prices of nonfood manufactures. 


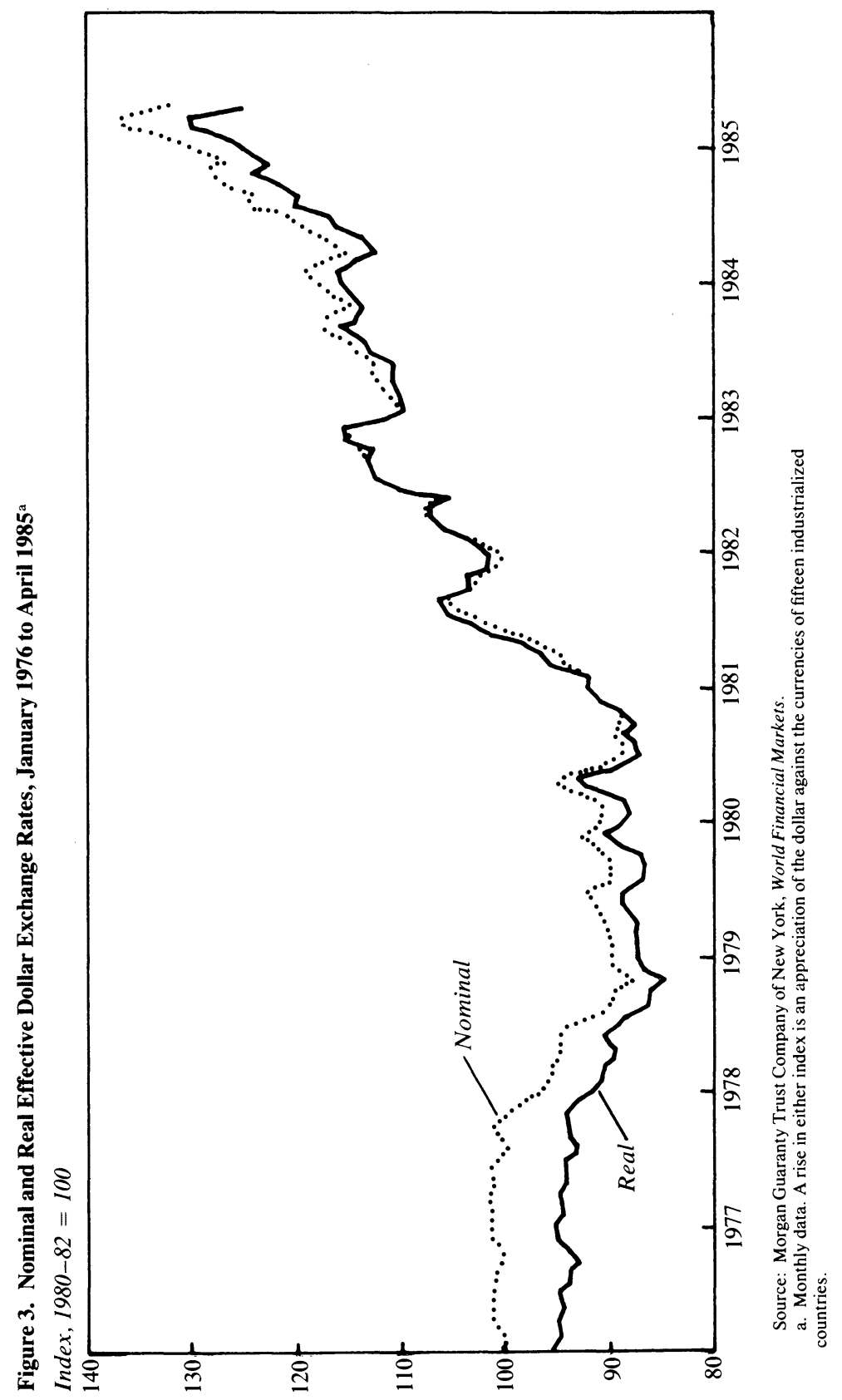


helped initiate a protracted speculative attack on the dollar. The December 1971 Smithsonian realignment, which formally devalued the dollar relative to the currencies of most major industrial countries, entailed a substantial real depreciation of the dollar, albeit a smaller one than U.S. authorities had desired. But by the end of the year it was also clear that the United States had registered its first postwar annual merchandise trade deficit, a development apparently taken by the market as confirmation that further real depreciation would be required in the near future. Without a discrete revaluation of foreign currencies against the dollar, the transition to a real exchange rate consistent with a balanced U.S. current account would have called for a period of stagnating economic activity in the United States and a further rise in relative foreign price levels-a process neither the Nixon administration nor foreign governments seemed willing to tolerate. This realization led to further speculative runs on the dollar, further dollar devaluation, and, finally, the abandonment of fixed rates in 1973. On the basis of relative wholesale prices, the dollar's real value in terms of foreign currencies fell by 18.6 percent between 1969 and 1973; its real depreciation on the basis of unit labor costs was 28.4 percent over that period. Not until 1982 did the U.S. real exchange rate again approach the level from which it had been devalued by the Smithsonian agreement.

\section{THE BEHAVIOR OF MANUFACTURING EMPLOYMENT}

The effect of exchange rate movements on the manufacturing sector has been at the center of the discussion of the dollar's real appreciation. By lowering the prices of imports relative to those of domestic exports and import-competing goods, a real appreciation tends to lower the demand for a country's tradable goods. This, in turn, contracts the manufacturing sector, where the production of nonagricultural tradables is concentrated.

Figure 4 shows the ratio of manufacturing employment to total nonagricultural employment in the United States, Germany, and Japan since 1960. After 1970, all three countries show a declining trend in the manufacturing employment ratio, but the trend is most pronounced, and begins earliest, in the United States. Because measured labor productivity grows more quickly in manufacturing than in other sectors of the economy, such a trend is natural for an advanced economy and need not 
Figure 4. Share of Manufacturing Employment in Total Nonagricultural Employment, 1960-84

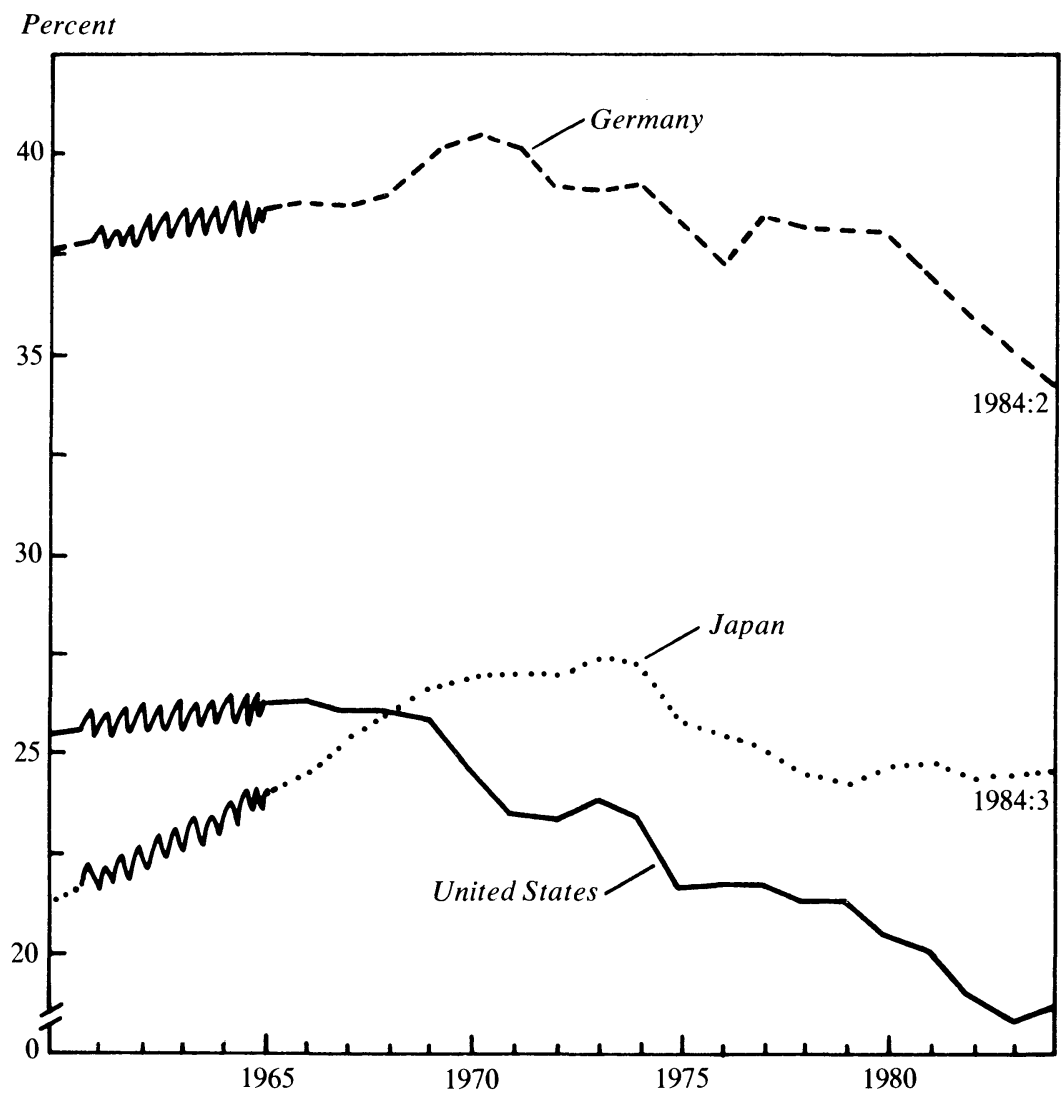

Source: U.S. Department of Commerce, International Economic Indicators.

a. Annual data, except quarterly in 1984 for Germany and Japan. Data not available for 1961-65.

imply a shift in the composition of national output away from manufacturing. However, labor productivity has grown somewhat more slowly in the United States than in Germany, and much more slowly in the United States than in Japan.

A striking feature of the experience in the United States is the role of recessions in accelerating the secular exodus of labor from manufacturing. Apparently, recessions put some marginal firms out of business and force other such firms to shed excess labor permanently. The figure shows particularly sharp reductions in the U.S. manufacturing employ- 
ment ratio in 1969-71, 1973-75, and 1979-82, all periods of recession. The sharp contraction of U.S. manufacturing employment over 1979-83 has suggested to many observers a linkage between the real exchange rate and the size of the U.S. manufacturing sector. However, the 196971 contraction occurred against the background of a depreciating real exchange rate, as documented earlier. Further, figures for 1984 show a rise in the U.S. manufacturing employment ratio and, in fact, a substantial (5.8 percent) expansion in the level of employment in manufacturing and mining.

These considerations suggest that the relation between the real exchange rate and the sectoral allocation of resources is not a simple one, but depends on the nature of the disturbance moving the real exchange rate. For example, an increase in foreign demand for domestic manufactures will cause a currency appreciation and an expansion in the manufacturing sector. But a restrictive shift in domestic monetary policy will cause a currency appreciation coupled with a contraction in the manufacturing sector; and an increase in domestic spending that falls on nonmanufactures may produce the same result. I return to this point later on. ${ }^{9}$

The cyclical behavior of the manufacturing employment ratio in Germany is broadly similar to that in the United States, but there are some differences. For example, the decline in the ratio following the first oil shock begins and ends later in Germany, and is followed by a strong rebound between 1976 and 1979, a period in which the deutsche mark appreciated sharply against the dollar. As in the United States, the share of German manufacturing in total employment has declined significantly

9. Solomon shows that the ratio of manufacturing value added to GNP did not decline between 1980 and 1984 when both are measured at 1972 prices. This is not the case when current dollars are used to measure outputs. See Robert Solomon, "Effects of the Strong Dollar," Brookings Discussion Papers in International Economics 35 (Brookings, September 1985). Arnold Kling, in "The Dollar and the Demand for Labor in Manufacturing: The Case of the Missing Effect" (Board of Governors of the Federal Reserve System, September 1985), finds that over 1974-84 the exchange rate has no explanatory power in a regression of a manufacturing employment ratio index on current and lagged gross national product. As Solomon observes, some U.S. manufacturing industries have been hurt by the shifts causing the dollar's appreciation, but others, such as defense-related industries, have experienced favorable demand shifts. The same conclusion is reached on the basis of disaggregated data in Morgan Guaranty Trust Company of New York, "The Bonn Summit and the U.S. Trade Deficit," World Financial Markets (March-April 1985), pp. 1-13. 
Table 1. Annual Percentage Growth Rates of Real Gross National Product in Major Industrial Countries, 1977-84

\begin{tabular}{lcccrrrrr}
\hline \multicolumn{1}{c}{ Country } & 1977 & 1978 & 1979 & 1980 & 1981 & 1982 & 1983 & 1984 \\
\hline United States & 5.5 & 5.0 & 2.8 & -0.3 & 2.5 & -2.1 & 3.7 & 6.8 \\
Japan & 5.3 & 5.1 & 5.2 & 4.8 & 4.0 & 3.3 & 3.4 & 5.8 \\
Canada & 2.0 & 3.6 & 3.2 & 1.1 & 3.3 & -4.4 & 3.3 & 4.7 \\
France & 3.1 & 3.8 & 3.3 & 1.1 & 0.2 & 2.0 & 0.7 & 1.8 \\
Germany & 2.8 & 3.4 & 4.0 & 1.9 & -0.2 & -1.1 & 1.3 & 2.6 \\
Italy & 1.9 & 2.7 & 4.9 & 3.9 & 0.2 & -0.5 & -0.4 & 2.6 \\
United Kingdom & 3.0 & 4.0 & 3.2 & -2.6 & -1.4 & 2.4 & 3.2 & 2.4 \\
\hline
\end{tabular}

Source: International Monetary Fund, World Economic Outlook 1985 (Washington, D.C.: International Monetary Fund, April 1985).

a. Figures are growth rates from the preceding year. For France, Italy, and the United Kingdom, growth rates of gross domestic product at market prices are reported.

in the recent recession, but the decline has occurred in spite of the real depreciation of the deutsche mark. In Japan the manufacturing employment ratio has been essentially flat since 1978. As in the United States, however, a sharp, permanent decline followed the 1973-74 price shock. It is noteworthy that Japanese manufacturing employment remained strong in the face of a real effective appreciation of the yen in 1982-84.

\section{RECOVERY：A COMPARATIVE APPRAISAL}

It has been widely observed that the recovery from the last recession has been unbalanced, most rapid in the United States, quite slow in Europe. Table 1 shows annual growth rates of the major industrial countries' real gross national products since 1977.

The table confirms that GNP growth since 1982 has been much more rapid in the United States, Japan, and Canada than in the major industrial countries of Europe. In 1984 the recovery strengthened everywhere save the United Kingdom. But the acceleration of growth between 1983 and 1984 was most dramatic in the United States, Japan, and Italy. With their extensive trade linkages to the United States, Japan and Canada have been the prime beneficiaries of the rapid increase in U.S. aggregate demand during the recovery.

Mirroring this asymmetric output performance has been the behavior of employment. Between 1983 and 1984, the unemployment rate came down sharply in the United States and less dramatically in Canada; it remained unchanged (at 2.7 percent) in Japan, where the effect of 
Table 2. Current Account Balances of Major Industrial Countries, 1977-84a Billions of U.S. dollars

\begin{tabular}{lrrrrrrrr}
\hline \multicolumn{1}{c}{ Country } & 1977 & \multicolumn{1}{c}{1978} & \multicolumn{1}{c}{1979} & 1980 & 1981 & 1982 & 1983 & 1984 \\
\hline United States & -14.5 & -15.5 & -1.0 & 1.9 & 6.3 & -9.2 & -41.6 & -101.6 \\
Japan & 10.9 & 16.5 & -8.8 & -10.7 & 4.8 & 6.9 & 20.8 & 35.0 \\
Canada & -4.1 & -4.3 & -4.1 & -1.0 & -5.1 & 2.2 & 1.4 & 1.5 \\
France & -0.4 & 7.0 & 5.2 & -4.2 & -4.8 & -12.1 & -4.5 & n.a. \\
Germany & 4.1 & 9.0 & -6.1 & -15.8 & -5.8 & 3.6 & 4.1 & 6.3 \\
Italy & 2.5 & 6.2 & 5.5 & -9.7 & -8.2 & -5.5 & 0.8 & -3.2 \\
United Kingdom & 0.1 & 2.2 & -1.1 & 8.1 & 14.1 & 8.5 & 3.5 & 0.3 \\
\hline
\end{tabular}

Source: International Monetary Fund, World Economic Outlook 1985.

a. Including official transfers.

recession on measured unemployment had been relatively mild. In Germany, however, the unemployment rate dropped only marginally in 1984, while in France, Italy, and the United Kingdom it actually rose. Overall employment levels fell in that year in both France and Germany.

Current accounts have also reflected the unbalanced growth among the industrialized countries. The current account surplus is the excess of an economy's income over its absorption of goods and services; alternatively, it may be viewed as the difference between exports of goods and services (plus net transfers from abroad) and imports. Table 2 shows that in the course of the recovery, the U.S. current account deficit and the Japanese current account surplus have expanded to record levels. Canada and Germany also registered external surpluses in 1984.

The huge U.S. deficit is the counterpart of the surpluses abroad. The existence of external surpluses in Japan and Canada reinforces the impression that their relatively rapid growth is in part attributable to the spillover effects of U.S. aggregate demand. In particular, the large U.S. deficit implies that overall American demand has grown more rapidly than U.S. output in the recovery.

The demand patterns suggested by these data are important for understanding the recent behavior of exchange rates. Table 3 shows percentage changes in the seven countries' real effective exchange rates based on wholesale price indexes between 1980 and 1982 and between 1982 and 1984. In the first period there is a real effective appreciation of the U.S. dollar coupled with real depreciations of all other currencies but the Canadian dollar. In the second period the U.S. dollar's real appreciation continued, but the behavior of other currencies was more disparate. As noted earlier, the yen, while depreciating slightly in real 
Table 3. Percentage Changes in Real Effective Exchange Rates, 1980-84

\begin{tabular}{lrr}
\hline \multicolumn{1}{c}{ Country } & $1980-82$ & $1982-84$ \\
\hline United States & 24.1 & 10.9 \\
Japan & -1.2 & 9.9 \\
Canada & 5.3 & 2.2 \\
France & -10.1 & -5.2 \\
Germany & -4.0 & -3.8 \\
Italy & -5.5 & 1.1 \\
United Kingdom & -2.6 & -9.3 \\
\hline
\end{tabular}

Source: International Monetary Fund, International Financial Statistics.

a. Real effective exchange rates are based on relative wholesale prices. A positive number is an effective appreciation.

terms against the dollar, appreciated significantly on an effective basis. The currencies of France, Germany, and the United Kingdom all depreciated further in real effective terms between 1982 and 1984, while those of Canada and Italy appreciated slightly.

The policy backdrop to recession and recovery has been a concerted slowdown in monetary growth rates in major industrial countries, fiscal expansion in the United States, and a net fiscal contraction abroad. Recent trends in OECD fiscal policies have been surveyed by Olivier Blanchard and Lawrence Summers. ${ }^{10}$ The IMF's measure of fiscal impulse, which attempts to measure the exogenous contribution of government fiscal policy to demand, confirms their findings. Between 1980 and 1985 the cumulative expansionary fiscal impulse for the United States was 4.2 percent of U.S. GNP, while the fiscal impulse for the other six major industrial countries was contractionary and amounted to -3.2 percent of their total GNP. ${ }^{11}$

Table 4 shows average money growth rates over the periods 1976-79 and 1979-84. For Japan, Germany, and Italy, the change in M1 growth

10. Olivier J. Blanchard and Lawrence H. Summers, "Perspectives on High World Real Interest Rates," BPEA, 2:1984, pp. 273-324. See also Charles Wyplosz, "International Aspects of the Policy Mix in Six OECD Countries," prepared for the World BankBrookings Workshop on the International Consequences of Budgetary Deficits and the Monetary-Fiscal Policy Mix in the OECD (September 1984).

11. See International Monetary Fund, World Economic Outlook 1985 (Washington, D.C.: International Monetary Fund, April 1985), table 16, p. 221. The IMF's fiscal impulse measure is not strictly additive over time; the figures given in the text therefore exaggerate the extents of the cumulative expansionary impulse in the United States and the cumulative contractionary impulse abroad. Further, the IMF does not correct for the effect of inflation on the real value of nominal government liabilities. Data for 1985 are projections. 
Table 4. Average M1 Growth Rates of Major Industrial Countries, 1976-84a

Percent

\begin{tabular}{lcc}
\hline \multicolumn{1}{c}{ Country } & $1976-79$ & $1979-84$ \\
\hline United States & 7.8 & 7.6 \\
Japan & 9.2 & 3.6 \\
Canada & 9.1 & 10.0 \\
France & 11.0 & 10.0 \\
Germany & 9.7 & 4.0 \\
Italy & 22.1 & 13.1 \\
United Kingdom & 15.1 & 10.6 \\
\hline
\end{tabular}

Source: Author's calculations, based on data from International Monetary Fund, World Economic Outlook 1985. a. Each year's monetary growth rate is the percentage change in the money stock for that year over the previous year's money stock.

is dramatic. The deceleration of M1 growth in the United States appears to be insignificant, but recent U.S. money growth figures need to be interpreted with caution because of changes in financial regulations. Figures for "regulation-adjusted" M1 compiled by Alfred Broaddus and Marvin Goodfriend in fact show a sharp contraction in the growth of U.S. transaction balances over 1980-81, an acceleration over 1981-83, and relatively tight money again in $1983-84 .{ }^{12}$ Only in Canada is there an increase in average annual M1 growth between the two periods; however, data for Canadian M2 growth show a significant deceleration between 1980 and 1984.

The moderate slowdown in U.S. money growth relative to the sharper monetary slowdowns in Japan and Germany, even after adjustment for U.S. financial deregulation, indicates that shifts in monetary policy can have been at best part of the reason for the dollar's nominal and real appreciation since 1979. The obvious inadequacy of purely monetary explanations calls for a conceptual framework integrating both real and monetary factors. This is developed in the next section.

\section{Exchange Rate Theory and International Policy Interactions}

One argument in the 1960s case for exchange rate flexibility was that floating rates would insulate economies from foreign disturbances while

12. See Alfred Broaddus and Marvin Goodfriend, "Base Drift and the Longer Run Growth of M1: Experience from a Decade of Monetary Targeting," Federal Reserve Bank of Richmond Economic Review, vol. 70 (November-December 1984), pp. 3-14. 
freeing monetary policy to pursue domestic macroeconomic goals. The collapse of the fixed exchange rate system occurred at a time when the United States' OECD partners seemed indeed to have lost control of their domestic money supplies. They hoped that floating rates would sever the tie between U.S. and domestic prices and give them better control over macroeconomic developments at home. ${ }^{13}$

Experience has shown that the insulating properties of floating rates were exaggerated. Table 5 compares the matrix of correlations among U.S., Japanese, and German annual unemployment rates over the fixed rate years 1960-72 with corresponding correlation matrices for periods after 1972. (Unemployment rates are residuals from a regression of the measured unemployment rate on a constant and a time trend.) The coefficients are quite high in the first period, and a comparison of the fixed rate period to the floating rate period as a whole suggests that international synchronization of the business cycle has remained high. However, the two OPEC price shocks, which depressed activity around the world, are an obvious source of synchronization. When only years in which OPEC developments were not dominant are used, the United States-Japan correlation becomes quite small. But the United StatesGermany correlation and the Germany-Japan correlation remain positive and only slightly lower than during the years of fixed exchange rates. Correlations among monthly WPI inflation rates reinforce the impression that significant interdependence has remained under floating rates.

This section develops a framework for analyzing short- and mediumterm interdependence under floating and fixed exchange rates. The results provide a basis for understanding the experience surveyed above, and a background for discussion of how different exchange rate systems perform. The conclusions reached illustrate why early expectations about the functioning of floating rates were fulfilled only partially. By adopting a floating rate, a monetary authority regains the control over its nominal money supply that it sacrifices under a fixed rate. But a floating rate does not automatically shield the economy from the repercussions of macroeconomic developments abroad. A floating rate can cushion some sectors of the economy in the face of certain shocks, but a change in a nominal variable like the exchange rate can never offset

13. The classic academic case for flexible rates during this period was made by Harry G. Johnson in "The Case for Flexible Exchange Rates, 1969,"' Federal Reserve Bank of St. Louis Review, vol. 51 (June 1969), pp. 12-24. 
Table 5. Correlation Matrix of Annual Unemployment Rates: the United States, Japan, and Germany, 1960-84

\begin{tabular}{lccc}
\hline \multicolumn{1}{c}{ Country } & $\begin{array}{c}\text { United } \\
\text { States }\end{array}$ & Japan & Germany \\
\hline United States & \multirow{3}{*}{$1960-72$} \\
Japan & & 0.75 & 0.58 \\
Germany & & 1.00 & 0.93 \\
& & & 1.00 \\
United States & 1.00 & 0.50 & 0.69 \\
Japan & & 1.00 & 0.83 \\
Germany & & & 1.00 \\
& & 1976-78 and $1981-84$ & \\
United States & 1.00 & 0.15 & 0.49 \\
Japan & & 1.00 & 0.85 \\
Germany & & & 1.00 \\
\hline
\end{tabular}

Source: Author's calculations, based on data from Organization for Economic Cooperation and Development, Main Economic Indicators.

a. Correlations are between the residuals from regressions of unemployment rates on a constant and a linear time trend.

completely the effects of a real disturbance originating abroad. In the long run a floating rate can shut out foreign trend inflation and allow the central bank to choose its preferred trend inflation rate. But in the short run even monetary shocks will be transmitted between countries.

\section{EXCHANGE RATES AND PRICES IN A GLOBAL MODEL}

The model developed here extends to a global setting the Keynesian asset-market approach to exchange rates. That approach emphasizes the rapid adjustment of asset markets relative to goods markets, and the exchange rate's role in maintaining continuous portfolio balance, given expectations about the future. At the same time, the model emphasizes that these expectations are based on the exchange rate's key role in determining the equilibrium terms of trade between national outputs over the longer term. Indeed, this alternative role of the exchange rate is the key to understanding the impact of aggregate demand disturbances, including fiscal policies. Deviations between the short-run and fullemployment equilibrium of the world economy arise from the prenegotiation of nominal wage contracts. Full-employment equilibrium is attained over a span of time in which wage contracts can adjust to disturbances that were not expected when the contracts were written. 
The model focuses on short- and medium-term price-output dynamics, and does not explicitly incorporate the current account or investment, which play key roles in determining the long-run equilibrium of the world economy. I therefore distinguish between full-employment (or mediumterm) equilibrium and the true long-run equilibrium reached once asset stocks have also adjusted to steady-state levels. ${ }^{14}$

In view of the wide swings in real exchange rates documented earlier, a realistic model must recognize that different economies produce distinct output baskets. For the moment I consider each region's output to be a single composite commodity and focus on the aggregate implications of disturbances. Sectoral issues revolving around the distinction between tradables and nontradables turn out to be of crucial importance in assessing the performance of floating rates, however, and are taken up at the end of this section.

Aggregate demand $y_{t}^{d}$ for the home region's output is a function of the real exchange rate $q_{t}$, the domestic real interest rate $r_{t}$, foreign output $y_{t}^{*}$, and a demand shock $g_{t}$. A similar relationship (in which the foreign counterparts of domestic symbols are marked by asterisks) governs aggregate demand for foreign output:

$$
\begin{gathered}
y_{t}^{d}=\delta q_{t}-\sigma r_{t}+\gamma y_{t}^{*}+g_{t}, \\
y_{t}^{* d}=-\delta^{*} q_{t}-\sigma^{*} r_{t}^{*}+\gamma^{*} y_{t}+g_{t}^{*} .
\end{gathered}
$$

14. The Keynesian asset-market approach is developed in Rudiger Dornbusch, "Expectations and Exchange Rate Dynamics," Journal of Political Economy, vol. 84 (December 1976), pp. 1161-76; William H. Branson, "Exchange Rate Dynamics and Monetary Policy," in Assar Lindbeck, ed., Inflation and Employment in Open Economies (Amsterdam: North-Holland, 1979), pp. 189-224; Jeffrey A. Frankel, "On the Mark: A Theory of Floating Exchange Rates Based on Real Interest Differentials," American Economic Review, vol. 69 (September 1979), pp. 610-22; Michael Mussa, "A Model of Exchange Rate Dynamics," Journal of Political Economy, vol. 90 (February 1982), pp. 74-104; Willem H. Buiter and Marcus Miller, "Real Exchange Rate Overshooting and the Output Cost of Bringing Down Inflation," European Economic Review, vol. 18 (May 1982), pp. 85-123; Maurice Obstfeld, "Relative Prices, Employment, and the Exchange Rate in an Economy with Foresight," Econometrica, vol. 50 (September 1982), pp. 1219-42; and Robert P. Flood and Robert J. Hodrick, "Optimal Price and Inventory Adjustment in an Open-Economy Model of the Business Cycle," Quarterly Journal of Economics, forthcoming. The global extension of this approach builds on Robert A. Mundell, International Economics (Macmillan, 1968), chapter 18. A similar global model underlies the analysis in Betty C. Daniel, "The International Transmission of Economic Disturbances under Flexible Exchange Rates,' International Economic Review, vol. 22 (October 1981), pp. 491-509, and Kenneth Rogoff, "Can International Monetary Policy Cooperation Be Counterproductive?' Journal of International Economics, vol. 18 (May 1985), pp. 199-217. 
Above, $q_{t}$ is the price of foreign output in terms of domestic output. All lowercase variables other than interest rates are natural logarithms.

Let $e_{t}$ denote the nominal exchange rate, the price of foreign currency in terms of domestic currency; and let $p_{t}\left(p_{t}^{*}\right)$ denote the domestic-money (foreign-money) price of domestic (foreign) output. Then the real exchange rate $q_{t}$ is defined as:

$$
q_{t}=e_{t}+p_{t}^{*}-p_{t}
$$

A rise in $q_{t}\left(e_{t}\right)$ is called a real (nominal) depreciation of the domestic currency. If $i_{t}$ and $i_{t}^{*}$ are the home and foreign nominal interest rates, real interest rates are:

$$
r_{t}=i_{t}-\left({ }_{t} p_{t+1}-p_{t}\right), \quad r_{t}^{*}=i_{t}^{*}-\left({ }_{t} p_{t+1}^{*}-p_{t}^{*}\right),
$$

where the notation ${ }_{t} x_{t}$ refers to the expected value of a variable $x_{t}$ based on information known at time $t^{\prime}$.

Aggregate output supplies in the two regions, $y_{t}^{s}$ and $y_{t}^{* s}$, depend negatively on real output wages:

$$
y_{t}^{s}=\theta\left(p_{t}-w_{t}\right), \quad y_{t}^{* s}=\theta^{*}\left(p_{t}^{*}-w_{t}^{*}\right) .
$$

Nominal wages $w_{t}$ and $w_{t}^{*}$ are negotiated at time $t-1$, and are predetermined as of time $t$. Wages in the two regions are set according to the rules,

$$
w_{t}={ }_{t-1} p_{t}, \quad w_{t}^{*}={ }_{t-1} p_{t}^{*},
$$

that is, so as to equate outputs to full-employment levels (normalized so that their natural logarithms equal zero). Partial ex post indexation of these wages to the price of domestic output can be viewed as a reduction in the supply elasticities $\theta$ and $\theta^{*}$. For simplicity I assume wages are not indexed directly to import prices. This is an innocuous assumption if both regions are large enough to prevent one region's exports from making up a very large share of the other region's consumption basket. ${ }^{15}$

15. Let $\Omega$ be the indexation parameter $(0 \leq \Omega \leq 1)$ and let $\alpha$ be the share of domestic output in home-region consumption. With wages indexed to the CPI rather than to the price of domestic output, the home aggregate supply function would be expressed as $y_{t}^{s}=\theta\left[(1-\Omega)\left(p_{t}-w_{t}\right)-\Omega(1-\alpha) q_{t}\right]$. A similar aggregate supply function would result from the assumption that foreign output is an intermediate input to domestic production. The assumption that imports are not an important component of the overall price level is reflected in the definitions of real interest rates above and real-balance deflators below. Branson and Rotemberg use a two-region model similar in structure to the one explored here to study the importance of differential wage-indexing conventions across regions. See William H. Branson and Julio J. Rotemberg, "International Adjustment with Wage Rigidity," European Economic Review, vol. 13 (May 1980), pp. 309-32. 
Consider next the asset markets. If $m_{t}$ and $m_{t}^{*}$ denote the home and foreign money supplies (net of exogenous money-demand shift factors), the monetary equilibrium conditions for the two regions are written:

$$
m_{t}-p_{t}=\phi y_{t}-\lambda i_{t}, \quad m_{t}^{*}-p_{t}^{*}=\phi^{*} y_{t}^{*}-\lambda^{*} i_{t}^{*} .
$$

The defining feature of a floating rate regime is that each region's nominal money supply depends only on the decisions of its own monetary authority. Nominal interest rates are linked by the interest parity condition,

$$
i_{t}=i_{t}^{*}+{ }_{t} e_{t+1}-e_{t},
$$

so that a positive differential between the home and foreign nominal interest rates requires an offsetting expected nominal depreciation of the home currency against the foreign currency. ${ }^{16}$ It is a direct consequence of nominal interest parity that the home-foreign real interest differential equals the expected rise in the real exchange rate:

$$
r_{t}-r_{t}^{*}={ }_{t} q_{t+1}-q_{t} .
$$

When a currency is expected to depreciate in real terms, the domestic real interest rate exceeds the real interest rate prevailing abroad.

Aggregate output fluctuations arise in the model from output price movements that are not fully reflected in contemporaneous nominal wage changes. Real wage movements, in turn, are the result of changes in output demands or money supplies that were not foreseen at the time wages for the period were set. As a prelude to analyzing short-run international adjustments to such shocks, it is useful to examine the fullemployment or perfect-foresight equilibrium of the model.

\section{FULL-EMPLOYMENT EQUILIBRIUM:}

INTERDEPENDENCE IN THE MEDIUM RUN

Suppose initially that the aggregate demand shift parameters are expected to remain constant at $g$ and $g^{*}$, while money supplies are expected to grow forever at the constant rates $\mu$ and $\mu^{*}$. Then in the absence of current expectational errors, interest rates and prices are given by:

16. An exogenously varying risk premium could be appended to this equality without changing the main results derived below. I discuss the evidence on the interest parity condition in the final section. 


$$
\begin{gathered}
r=r^{*}=\frac{\delta g^{*}+\delta^{*} g}{\delta^{*} \sigma+\delta \sigma^{*}} \\
q=\frac{\sigma g^{*}-\sigma^{*} g}{\delta^{*} \sigma+\delta \sigma^{*}} \\
p=m+\lambda i=m+\lambda\left(\mu+\frac{\delta^{*} g+\delta g^{*}}{\delta^{*} \sigma+\delta \sigma^{*}}\right), \\
p^{*}=m^{*}+\lambda^{*} i^{*}=m^{*}+\lambda^{*}\left(\mu^{*}+\frac{\delta^{*} g+\delta g^{*}}{\delta^{*} \sigma+\delta \sigma^{*}}\right), \\
e=m+\lambda \mu-m^{*}-\lambda^{*} \mu^{*} \\
+\frac{\left[\delta^{*}\left(\lambda-\lambda^{*}\right)-\sigma^{*}\right] g+\left[\delta\left(\lambda-\lambda^{*}\right)+\sigma\right] g^{*}}{\delta^{*} \sigma+\delta \sigma^{*}} .
\end{gathered}
$$

As explained in the appendix, these equations depend on a convergence condition that excludes self-fulfilling speculative bubbles.

These formulas have a number of important implications about macroeconomic interdependence under floating rates. First, because the full-employment real exchange rate is expected to remain constant under the present assumptions, home and foreign real interest rates coincide. Equation 1 states that an increase in aggregate demand falling on home or foreign goods increases the world real interest rate. An implication is that expansionary fiscal policy in either region will drive up the international real interest rate. Even when all prices are flexible, floating rates provide no insulation from changes in the world real interest rate.

Second, the domestic currency appreciates in real terms (that is, $q$ falls) when demand for domestic goods increases, but it depreciates when demand for foreign goods increases (equation 2). In particular, expansionary fiscal policy at home entails a real appreciation. The result gives a theoretical rationale for the observed association between the recent evolution of OECD fiscal policies and the dollar's real appreciation, as discussed later. Purchasing power parity does not hold in the model in all circumstances, so real exchange rate changes provide another mechanism through which macroeconomic disturbances are propagated internationally.

Third, equations 3 and 4 imply that global aggregate demand shocks, and in particular fiscal policies, affect price levels throughout the world. For example, fiscal expansion in either region must eventually drive up 
the price level in both regions. The reason is that any increase in global aggregate demand drives up the world real interest rate, and, for given money growth rates, drives up each region's nominal interest rate, reducing desired real balances. A floating exchange rate does not provide insulation for national price levels in general.

In what sense, then, do floating rates provide insulation? The equations above show that floating rates provide insulation in the medium run only against purely monetary shocks originating abroad. Across fullemployment equilibriums, changes in money supplies and money growth rates do not affect the world real interest rate or $q$, reflections of the monetary neutrality assumed by the model. A rise in $m$ or $\mu$, for example, raises $p$, but it does not affect $p^{*}$. A rise in $e$ just equal to the associated rise in $p$ prevents any purely monetary disturbance from affecting $q$ (compare equations 3 and 5).

The nominal exchange rate does not always move so as to offset divergent output price movements, however: the exchange rate depends on real as well as monetary factors, even at full employment. The reason is that the exchange rate plays a role in equilibrating goods as well as asset markets. If the interest elasticities of money demand are similar across countries, growth in demand for foreign output must depreciate the domestic currency in nominal terms while growth in demand for domestic output must appreciate it. Indeed, if $\lambda=\lambda^{*}$, equation 5 becomes:

$$
e=m+\lambda \mu-m^{*}-\lambda^{*} \mu^{*}+q .
$$

If there are substantial real shocks to the system, one would expect $e$ and $q$ to be highly correlated because part of the adjustment of $q$ to a real disturbance changing the relative price of national outputs is accomplished through a movement in $e$. This observation provides one theoretical explanation for the high correlation between real and nominal exchange rate changes shown for the United States in figure 3 and characteristic of all major currencies over the floating rate period.

By relaxing the assumptions that expected money growth is constant and that no aggregate demand shifts are expected, one obtains a more general representation of the model's full-employment equilibrium. A full derivation is given in the appendix. More general expectational assumptions lead to an explicit account of the key role that expectations about the future play in determining current prices and interest rates. 
The more general expression for the full-employment real exchange rate is:

$$
q_{t}=\frac{1}{\sigma \sigma^{*}+\delta \sigma^{*}+\delta^{*} \sigma} \sum_{j=0}^{\infty}\left(\frac{\sigma \sigma^{*}}{\sigma \sigma^{*}+\delta \sigma^{*}+\delta^{*} \sigma}\right)^{j}\left(\sigma_{t} g_{t+\mathrm{j}}^{*}-{\sigma^{*}}_{t} g_{t+j}\right) .
$$

Equation 6 shows that the real exchange rate depends not only on the current state of aggregate demand at home and abroad, but on the entire expected path of aggregate demand. For example, an anticipated tightening of fiscal policy at home (a fall in $g_{t+j}$ for $j>0$ ) leads to a real depreciation today, even before the policy change is implemented, by raising expected home-foreign real interest differentials and, along with them, the current real interest differential. As before, each region's price level is insulated in the medium run from current or expected foreign monetary shocks but not from current or expected foreign demand shocks.

The foregoing analysis shows that in the medium run, a floating rate insulates a country from changes in the level or growth rate of foreign money, and thus allows it to choose its own trend rate of inflation without regard to monetary conditions abroad. But while the exchange rate can offset foreign monetary shocks, it is powerless to offset real disturbances from abroad when domestic goods and capital markets are at all integrated into the rest of the world's markets. To the extent that foreign monetary shifts have temporary real effects, a floating exchange rate will fail to insulate against these too in the short run. I now turn to a more detailed discussion of the international transmission of disturbances under floating rates.

\section{MACROECONOMIC ADJUSTMENT IN THE SHORT RUN}

The international transmission of monetary shocks in the short run is illustrated here by a permanent, unanticipated slowdown in the rate of home money growth $\mu$. As the appendix shows in detail, a fall in $\mu$ will, for plausible parameter configurations, put downward pressure on domestic output and prices but at the same time cause foreign output and prices to rise relative to their trends. ${ }^{17} \mathrm{~A}$ floating rate does not

17. My discussion of the model's implications assumes that domestic and foreign parameters are approximately equal. As explained later, $\delta$ and $\delta^{*}$ are related and will be 
prevent the international transmission of monetary shocks in the short run, and this transmission is likely to be negative.

Through what channels does negative transmission occur? Real domestic currency appreciation (a fall in $q$ ) puts downward pressure on domestic prices, output, and the nominal interest rate, but the same demand shift that causes recession at home pushes foreign prices and output upward. The direct effect of $y$ on the demand for foreign goods (measured by $\gamma^{*}$ ) tends to depress output abroad, but this effect is assumed to be dominated by the demand shift induced by the fall in $q$.

The behavior of world real interest rates is of particular interest in the likely case where foreign output does rise. Both the nominal and real interest rates prevailing abroad increase in the face of an incipient excess demand for real balances and a fall in expected inflation. Since the real exchange rate $q$ is now temporarily below its expected future level, and expected to rise, real interest rate parity implies that the home real interest rate must rise on impact as well. If disinflation at home raises foreign output, it therefore causes a rise in the domestic real interest rate and a somewhat smaller rise in the foreign real interest rate. The rise in the foreign real rate occurs even in the absence of any foreign monetary response to the domestic policy spillover.

Consider next the effects of fiscal expansion at home, formally represented as a permanent, unanticipated rise in $g$. Fiscal expansion at home causes a coordinated increase in output and prices both at home and abroad. Temporary fiscal expansion has the same qualitative effects on outputs and price levels in the short run. A detailed derivation is again provided in the appendix.

What is the impact of the disturbance on asset prices? The domestic currency appreciates in real and in nominal terms as the expected future levels of $e$ and $q$ decline; indeed, it is the change in the real exchange rate that transmits the increase in aggregate demand abroad. Nominal interest rates rise worldwide to maintain money-market equilibrium in the face of the activity and price level increases. The increase in nominal interest rates is likely to represent an increase in real interest rates as well.

close when the two regions are of roughly equal size. The short-run price and output effects of changes in $m$ and $m^{*}$, whether permanent or transitory, are qualitatively similar to the effects of changes in $\mu$ and $\mu^{*}$. 
It was observed earlier that even across full-employment equilibriums, changes in real and in nominal exchange rates tend to be positively correlated when real shocks occur. This same correlation characterizes the short-run response to both monetary and real disturbances when some prices in the economy are sticky. This is another reason for the high correlation between the real and nominal exchange rate changes shown in figure 3 . In the case of domestic disinflation, nominal appreciation reduces domestic prices and raises those abroad. But sticky nominal wages induce output movements that prevent output prices from adjusting completely to their PPP levels. The nominal appreciation is therefore accompanied by a temporary real appreciation, even though the monetary shock leaves steady-state relative prices unchanged. Domestic fiscal expansion also leads to both real and nominal appreciation in the short run. Unlike monetary policies, however, permanent fiscal policies have permanent effects on the real exchange rate.

\section{FIXED EXCHANGE RATES AND MONETARY AUTONOMY}

The behavior of the world economy under fixed exchange rates can also be studied within the framework set out above. When central banks intervene in the foreign exchange market, they create or destroy highpowered money. The monetary effect of intervention can be sterilizedthat is, offset through opposite variations in the domestic component of the monetary base. But the overwhelming conclusion of recent research is that in the present international environment, only intervention that is permitted to affect the money supply has a significant impact on the exchange rate. ${ }^{18} \mathrm{~A}$ commitment to peg the exchange rate therefore forces a central bank to devote monetary policy to that end.

Linkages among national money supplies depend heavily on the

18. This conclusion was reached by the Working Group on Exchange Market Intervention in "Report of the Working Group on Exchange Market Intervention"' (Jurgensen Report, U.S. Treasury, 1983). See also Maurice Obstfeld, "Exchange Rates, Inflation, and the Sterilization Problem: Germany, 1975-1981," European Economic Review, vol. 21 (March-April 1983), pp. 161-89; Kenneth Rogoff, "On the Effects of Sterilized Intervention: An Analysis of Weekly Data," Journal of Monetary Economics, vol. 14 (September 1984), pp. 133-50; and Bonnie E. Loopesko, "Relationships among Exchange Rates, Intervention, and Interest Rates: An Empirical Investigation," Journal of International Money and Finance, vol. 3 (December 1984), pp. 257-77. Sterilized intervention would be effective if capital controls were imposed, but the model assumes capital mobility. 
mechanism through which central banks settle balances of international payments. To illustrate the sense in which countries other than the United States sacrificed domestic monetary autonomy to peg dollar exchange rates before the system collapsed in 1973, I model a dollarstandard system. In that system, the foreign monetary authority pegs the exchange rate at $e$ through open market exchanges of its own highpowered money for foreign bonds; but the home, that is, U.S., central bank is not obliged to vary its money supply, when the foreign central bank buys or sells dollar assets.

The most important property of the resulting model is that by pegging the exchange rate, the foreign central bank relinquishes any ability to influence its own money supply through its own monetary policies. Further, the foreign country must accept the trend inflation rate established by the U.S. central bank, the reserve center, unless it can vary its exchange rate or its fiscal stance continuously over time for indefinite periods.

Alternative arrangements for settling official reserve balances would change the one-sidedness of the above arrangement. If both central banks held international reserves only in the form of an outside reserve asset such as gold or the IMF Special Drawing Right, interventionrelated monetary growth in one country would be matched by monetary contraction in the other. Alternatively, symmetric adjustment would be guaranteed if, as Ronald McKinnon has proposed, the foreign central bank pegged its rate to the home currency but held international reserves in the form of interest-bearing deposits at the home central bank. ${ }^{19}$

I begin as before by discussing the model's full-employment equilibrium under the assumption that all shifts to aggregate demand and homecountry monetary growth are regarded as permanent by the public. Equilibrium in the two goods markets implies that the real exchange rate $q$ is again given by equation 1 , while real interest rates are equalized internationally and given by equation 2 . The full-employment real exchange rate and real interest rate are therefore independent of the exchange rate regime. This point has important policy implications because it tells us that adjustments to permanent real shocks must eventually be made whether the exchange rate is fixed or floating. Under

19. See Ronald I. McKinnon, “A New Tripartite Monetary Agreement or a Limping Dollar Standard?" Essays in International Finance 106 (Princeton University, International Finance Section, October 1974). 
floating rates the adjustment will occur quickly through an exchange rate change, while under fixed rates it will occur more slowly through changes in relative output prices.

The price of output in the home region is given by equation 3 , and also is the same as that in the flexible rate model. Because the home central bank does not intervene to influence the exchange rate, it can set its nominal money stock $m$ at any desired level. Accordingly, equation 3 is a reduced-form expression for the domestic output price in terms of its exogenous determinants.

The foreign money stock $m^{*}$ is endogenous, however, and beyond the control of the foreign monetary authority. With the nominal exchange rate fixed, the real exchange rate given by equation 1 , and the homecountry output price given by equation 3 , the foreign output price $p^{*}=$ $p-e+q$ is independent of foreign monetary policy. It is given by:

$$
p^{*}=m-e+\lambda^{*} \mu+\frac{(\sigma+\lambda \delta) g^{*}-\left(\sigma^{*}-\lambda \delta^{*}\right) g}{\delta^{*} \sigma+\delta \sigma^{*}} .
$$

If the foreign region does not wish to use fiscal policy to offset the effects of changes in home-region money or inflation, its only recourse is a change in the exchange rate parity $e$. Together with the world nominal interest rate $r+\mu, p^{*}$ determines the foreign money stock according to:

$$
m^{*}=p^{*}-\lambda^{*}(r+\mu) .
$$

In the short run, too, foreign monetary policy is ineffective: any foreign attempt at monetary expansion leads to an immediate and completely offsetting capital outflow. In contrast, monetary expansion by the reserve center leads to a synchronized output expansion as world interest rates fall and the foreign central bank is forced to expand its own money supply through purchases of foreign exchange.

The international transmission of aggregate demand shocks is asymmetric as well. A permanent and unanticipated fiscal expansion by the reserve center, for example, raises output at home but may lower output abroad. While the spillover of domestic demand onto foreign goods has a stimulative effect, there is a rise in the worldwide nominal interest rate that tends to discourage foreign demand. However, it can be shown that fiscal expansion abroad always raises home output in the short run. This is again a consequence of the reserve center's unique control over its own money supply. Increased government demand in the foreign region 
leads to an increase in its output, its price level, its money stock, and the world interest rate. Because the home money supply is fixed, equilibrium in its money market requires higher prices and output.

THE ROLE OF THE CURRENT ACCOUNT UNDER FLOATING RATES

The current account has been conspicuously absent from the preceding discussion. Expenditure shifts of the type studied above will generally imply current account imbalances that redistribute wealth between regions and shift regional aggregate demand schedules in opposite directions over time. Equation 6, which shows how the real exchange rate depends on expected future demand conditions, suggests that the anticipation of these shifts will have effects on prices and interest rates today. For example, expansionary fiscal policy at home implies a current account deficit and a long-run real depreciation that accommodates the export surplus needed to service an increased stock of external debt. The anticipation of this eventual depreciation tempers, but is unlikely to reverse, the real appreciation that fiscal ease initially causes. In equation 6 , the expectation of a prolonged home current account deficit can be viewed as imparting a downward time trend to the demand shift factor $g$ and an upward trend to $g^{*}$.

In general, the relationship between the current account and real exchange rate is quite complicated. The pattern of exchange rate adjustment during the transition to external balance will depend on the type of shock that disturbed the external balance in the first place. For example, a current account deficit that finances productive investment and a deficit that finances consumption spending will induce different exchange rate paths. In terms of equation 6 , an investment-led external deficit need not reduce future levels of domestic wealth and spending, but it will tend to raise $q$ above its static-expectations level by increasing future expected levels of domestic supply. ${ }^{20}$

The current account adjustment process-the predictable, gradual adjustment of absorption to income-is likely to be of minor consequence

20. A dynamic model of the current account incorporating domestic capital accumulation is analyzed in Maurice Obstfeld and Alan C. Stockman, "Exchange-Rate Dynamics," in Peter B. Kenen and Ronald W. Jones, eds., Handbook of International Economics, vol. 2 (Amsterdam: North-Holland, 1985), pp. 917-77. In that model, a current account deficit is accompanied by a nominally appreciating currency if the investment rate is sufficiently high. 
for the time series properties of current account and exchange rate data. The correlation patterns characterizing these data are instead dominated by continual and largely unanticipated shocks to goods and asset markets. This explains why a currency can, like the dollar between 1982 and early 1985, sustain a net appreciation in the face of growing current account deficits. The same expenditure shocks that have expanded the deficit have also appreciated the dollar, and they have swamped any tendency for the dollar to fall in response to increases in U.S. external indebtedness.

Any relationship between exchange rate and current account innovations is possible, with the precise outcome depending on the source of the current account shock. As already noted, fiscal expansion at home induces exchange rate appreciation and an external deficit on impact. In contrast, a shift in foreign demand from foreign goods toward the goods produced by the home country will induce on impact a domestic currency appreciation and a home current account surplus, provided investment does not react strongly. Because the demand shift occasions a temporary rise in home income and a temporary fall in foreign income, capital will flow from the home to the foreign country as households in both smooth their expected consumption streams.

The current account movements caused by various demand shifts reflect changes in the level of absorption relative to income. But as the national income identities show, they also reflect changes in the level of imports relative to exports. By shifting expenditure between domestic and foreign goods, real exchange rate movements help produce demand and production patterns consistent with the desired current account balance. For example, the real appreciation accompanying an expansion of domestic absorption accommodates the required home import surplus by simultaneously discouraging exports and cheapening imports.

DEMAND SHIFTS AND RESOURCE ALLOCATION IN THE SHORT RUN

The assumption that each country produces a single homogeneous output must be dropped before the sectoral implications of expenditure shifts can be studied. For many purposes, it is useful to assume instead that the economy consists of two sectors, one producing tradable goods, and the other producing goods that are essentially nontradable. In this 
setting, demand disturbances must be viewed as shifting the allocation of productive factors between the two sectors over time. The earlier discussion of manufacturing employment in the United States, Japan, and Germany suggested that the relation between the real exchange rate and sectoral resource allocation is complex. The point can be appreciated by considering the contrasting effects of the demand shifts just noted.

An international demand shift toward domestic tradables occasions a nominal appreciation of the domestic currency, a rise in the money prices of home-produced tradables, and, through demand spillover effects, a proportionally smaller rise in the prices of nontradables. There is likely to be a real appreciation of the currency, but one that is accompanied by an expansion of the share of manufacturing employment in total employment. Increased output of tradables of course helps accommodate the concomitant export surplus. This scenario seems applicable to Japan, where manufacturing employment has not suffered greatly despite the yen's sharp real effective appreciation in 1982-84 (see figure 4).

A fiscal expansion that falls on nontradables, in contrast, induces a nominal appreciation and a rise in the money prices of nontradables. The effect on the demand for home-produced tradables is ambiguous, however. Fiscal expansion raises income by raising nontradable output, and part of the increased domestic spending that results falls on tradables. Possibly offsetting this expansionary effect is the exchange rate-induced rise in the price of exports relative to imports, which shifts domestic demand abroad. The result may well be a contraction in manufacturing employment coupled with a real appreciation. Ultimately, some labor and capital must leave the tradable sector to help satisfy the increased government demand for nontraded goods.

Because the tradable and nontradable sectors of the home economy use the same currency, they can be thought of as linked by a fixed exchange rate that floats against foreign rates. It follows that a fiscal expansion falling primarily on one of these sectors may have a contractionary effect on the other sector even as it stimulates output abroad.

\section{Optimum Currency Areas and the Misalignment Problem}

The theory of optimum currency areas, initiated by Robert Mundell in 1961, places in perspective some important elements of the cases for 
and against floating exchange rates and is a useful starting point for evaluating their recent performance. ${ }^{21}$ This section begins by discussing the theory's prescriptions for a world in which international asset trade is relatively unrestricted.

The notion of an optimum currency area arises from the observation that there may be costs, as well as benefits, in expanding the size of regions within which exchange rates are fixed. The benefits are basically those that motivate the use of monies as media of exchange and units of account. The possible costs are related to short-run macroeconomic performance, and arise from the reduction in monetary autonomy that a fixed exchange rate entails.

One way of thinking about the optimal currency area is as a "secondbest" policy regime. In a world without macroeconomic stabilization problems or adjustment costs, the informational convenience of fixed exchange rates, described later, would be a decisive argument against floating. Mundell's optimal currency area is a region of factor mobility within which there is some rigidity of nominal wage contracts and hence a possibility that nominal exchange rate flexibility can offset shocks that lead to employment and price level fluctuations. As Mundell recognized, the stabilizing properties of a floating rate might be minimal for small economies in which imports are so important a component of the cost of living that a reduction in real wages through nominal depreciation is impossible. But though the theory might not apply to individual countries within Europe or to Canada, for example, it is still useful in analyzing the effects of flexible dollar exchange rates on the European Monetary System (EMS) and Japan. ${ }^{22}$

As I emphasize later, however, a main drawback in viewing Europe, or even the United States, as a potential optimum currency area is that factors cannot move costlessly between sectors of the European and

21. See Robert A. Mundell, "A Theory of Optimum Currency Areas," American Economic Review, vol. 51 (September 1961), pp. 657-64. The theory is updated in Edward Tower and Thomas D. Willett, "The Theory of Optimal Currency Areas and ExchangeRate Flexibility," Special Papers in International Economics 11 (Princeton University, International Finance Section, 1976).

22. The desirability of fixed rates for very open economies was emphasized by Ronald I. McKinnon, "Optimum Currency Areas," American Economic Review, vol. 53 (September 1963), pp. 717-25. Note that Mundell's notion of factor mobility refers to the ability of workers and machines to move out of unemployed regions in the short run, not necessarily to international trade in financial assets. Economically, optimal currency areas need not coincide with political jurisdictions, but barriers to factor movement are often the result of actual or potential actions by national authorities. 
American economies. This problem is at the heart of the current concern about the effects of exchange rate misalignments and must be balanced against any aggregate benefits that exchange rate flexibility may confer.

\section{THE INFORMATIONAL BENEFITS OF LARGE CURRENCY AREAS}

By providing a widely accepted medium of exchange, money economizes on the substantial search costs associated with barter exchange. By providing a convenient unit of account, money also lowers calculation costs, provided the purchasing power of the monetary unit is itself stable. In a world of several currencies, the adoption of a single currency would therefore lower international transaction costs. The widespread use of the dollar as a means of payment and unit of account in international trade-particularly in trade involving the United States or between small countries-illustrates this point. Even under floating rates, markets will find it convenient to adopt a "vehicle currency" like the dollar. ${ }^{23} \mathrm{~A}$ further illustration is the growing private use of the European Currency Unit.

In practice, governments are unwilling to relinquish their currencycreating powers, so the ideal of a single world money is unattainable, at least at present. ${ }^{24}$ Fixed exchange rates can provide many of the informational benefits of a common world currency, however. The important difference-one that I discuss at greater length in the final section-is that governments may elect to change the price of their currency without warning. Indeed, it is in part to preserve this option that governments would be unwilling to give up national currencies in favor of a world currency issued by a supranational central bank. Within a single political jurisdiction, deposit insurance and related guarantees can ensure a fixed relative price between currency and other transactions

23. Evidence on the dollar's importance in international transactions is provided by Peter B. Kenen, "The Role of the Dollar as an International Currency,"' Occasional Paper 13 (Group of Thirty, 1983). A recent discussion of the theory of vehicle currencies is Paul Krugman, "The International Role of the Dollar: Theory and Prospect," in John F. O. Bilson and Richard C. Marston, eds., Exchange Rate Theory and Practice (University of Chicago Press, 1984), pp. 261-78. See also C. P. Kindleberger, "The Benefits of International Money," Journal of International Economics, vol. 2 (September 1972), pp. 425-42.

24. On the problems of creating and managing a common world currency, see Stanley Fischer, "The SDR and the IMF: Toward a World Central Bank?" in George M. von Furstenberg, ed., International Money and Credit: The Policy Roles (International Monetary Fund, 1983), pp. 179-99. 
media; but there are no similar institutions to ensure a fixed relative price between national currencies under all circumstances. The possibility of exchange rate changes limits the acceptability of national monies in trade under fixed rates, and limits their usefulness as numeraires by making their real value inherently more variable. Nonetheless, it can be argued that on balance there are informational gains from extending the domain over which exchange rates are fixed.

\section{EXCHANGE RATES AND MACROECONOMIC STABILITY}

What are the macroeconomic costs of fixing the exchange rate between two regions? Mundell linked his evaluation of these costs to two factors, the importance of shifts in the relative demand for the two regions' goods and the cost of interregional migration of unemployed capital and labor.

Macroeconomic performance under alternative exchange rate regimes can be studied in terms of the two-region model developed earlier, although most of the considerable body of recent research devoted to this question adopts a single-country perspective. The basic analytical framework assumes that authorities cannot directly observe whether shocks to the economy originate in goods or asset markets. Under these circumstances, the optimal exchange rate regime functions as an automatic stabilizer for the economy, yielding the best macroeconomic outcomes on average. Macroeconomic performance is evaluated in terms of the variability of output and the general price level relative to their trends. Each country's general price level is defined as a weighted average of the prices of its own output and imports. ${ }^{25}$

Assume first that the exchange rate is fixed, and suppose there is an increase in the relative demand for the home region's output. This shock, as we have seen, puts upward pressure on the home region's interest

25. An exchange rate regime optimal in the foregoing sense would generally involve neither fixed nor freely floating rates but something in between-a managed float. In practice, however, the information necessary to determine the optimal intervention strategy is unavailable to the authorities. For surveys of the theoretical literature on optimal intervention and exchange rate regime choice, see Dale W. Henderson, "Exchange Market Intervention Operations: Their Role in Financial Policy and Their Effects," in Bilson and Marston, eds., Exchange Rate Theory and Practice, pp. 359-406; and Richard C. Marston, "Stabilization Policies in Open Economies," in Kenen and Jones, eds., Handbook of International Economics, vol. 2, pp. 859-916. The Henderson and Marston reviews both go beyond the small-country paradigm. In the analysis below I abstract from supply shocks, which have an ambiguous exchange rate effect. 
rate, causing an incipient appreciation of its currency, a reduction in the foreign region's money supply, and an indeterminate change in foreign output. If the balance of payments adjustment mechanism operates symmetrically, as when the home region is not a reserve center, its money supply is increased by the inflow of private capital. Under a flexible exchange rate, the home currency would appreciate, thus shifting some of the demand shock to the foreign region and softening its effect on domestic employment, output, and prices. If demand shocks are important for both areas, a floating exchange rate may promote a better allocation of risks than a fixed rate would, in that each area will be able to export some of its macroeconomic variability abroad. In practice, the benefits of a flexible rate will be greatest when aggregate demand shocks are negatively correlated across regions, as when most shocks are absolute demand shifts between their outputs. In this situation-the situation Mundell assumed in his analysis-the gains from trading macroeconomic risk through a floating exchange rate are greatest. When aggregate demand shocks are dominant, therefore, floating exchange rates may well be preferred. ${ }^{26}$

The analysis of money-market shocks yields different conclusions. Consider the effect of an upward shift in the foreign money demand function. If the exchange rate is fixed and the home region is a reserve center, there is a transfer of reserves from the foreign central bank to the foreign public that restores foreign monetary equilibrium with no change in either region's output or price level. If reserve settlement is symmetric, however, the fall in foreign velocity causes a fall in the home money supply and a decline in activity in both regions: in effect, part of the velocity shock is exported abroad. Shocks to money demand or supply in a reserve center do have effects abroad, however, and these reinforce, rather than dilute, the shocks' domestic impact. A decline in velocity in a reserve center raises world interest rates in the short run, causing a decline in foreign output and money. But no corresponding increase in the domestic money supply automatically softens the fall in home output. It follows that macroeconomic performance under a fixed exchange rate depends crucially on the degree to which foreign exchange intervention affects the two regions' money supplies. A setup in which

26. When flexible rates are preferable on macroeconomic grounds, the informational benefits of fixing the rate are reduced by the incentives central banks have to alter the parity once it has become clear that a major real disturbance has occurred. 
the foreign central bank always intervenes and only its money supply is affected by intervention is clearly beneficial only when home monetary shocks are relatively insignificant. In general, the burden of adjusting the money supply to payments imbalances should fall more heavily on the region with the less stable monetary conditions.

Under a floating exchange rate, purely monetary shocks may cause output variability greater than that which could be achieved under a fixed rate. An exogenous increase in foreign money demand now puts upward pressure on the interest rate, causing an incipient capital inflow and an appreciation of the foreign currency. Because the exchange rate change shifts demand toward home-region goods, output and the price level in the foreign region fall by more than they would under a fixed rate, and are likely to rise in the home region. The risk-sharing argument suggests that the two regions will prefer a fixed exchange rate, together with appropriate international settlement arrangements, when monetary shocks are dominant, and especially when they are negatively correlated across regions, but will prefer a floating rate when aggregate demand shocks are the main concern. ${ }^{27}$

The analysis sketched above assumes a structure of nominal wage contracting and a distribution of shocks that are invariant with respect to the exchange rate regime. With respect to wage-setting arrangements, I present preliminary evidence later that there have been some structural changes outside the United States under flexible rates. However, the evidence is quite weak at this stage, and it is not at all clear that the shift to floating, per se, caused the changes. With respect to the structure of disturbances, McKinnon and others have argued that flexible exchange rates encourage instability in national money demands, although there is little solid evidence in support of this proposition. ${ }^{28}$

It is also noteworthy that there may be international disagreement about the appropriate exchange rate regime. Suppose that the home region is buffeted by substantial real shocks, while the primary cause of

27. Optimal risk pooling could be accomplished through full international diversification in all assets, including human capital. But this idealized situation cannot be attained in practice. For a model of a perfectly pooled international equilibrium, see Robert E. Lucas, Jr., "Interest Rates and Currency Prices in a Two-Country World," Journal of Monetary Economics, vol. 10 (November 1982), pp. 335-60.

28. See Ronald I. McKinnon, An International Standard for Monetary Stabilization, Policy Analyses in International Economics 8 (Institute for International Economics, 1984). 
disturbance abroad is monetary instability. The foreign central bank will then desire to peg to the home currency, but this will make it impossible for the home region to export any of its short-run demand variability abroad through exchange rate changes. In this situation the home region may resort to trade restrictions as a means of accomplishing what it cannot do through the foreign exchange market. This type of disagreement helped cause the "Nixon shock" of August 1971. Frustrated by its inability to devalue against foreign currencies in response to a perceived decline in U.S. competitiveness, the Nixon administration put pressure on foreign governments to revalue by imposing a 10 percent import surcharge. The resulting exchange rate realignments formed the substance of the Smithsonian agreement reached later that year.

AGGREGATE BENEFITS VERSUS SECTORAL COSTS:

THE MISALIGNMENT PROBLEM

The main implication of the foregoing discussion is that in spite of the advantages of a fixed rate system in terms of transaction costs, there may be substantial benefits to exchange rate flexibility between regions subject to differential aggregate demand shocks. The pattern of the recent recovery illustrates the potential benefits. Since 1982, dollar appreciation has moderated the effect of rising aggregate demand on U.S. output and prices by shifting that demand abroad. As already noted, Japan and Canada, with their extensive U.S. trading links, have been the main beneficiaries of this exported recovery, but Europe has benefited as well. Under fixed rates, the recovery would have been even more unbalanced than it has been, given existing macroeconomic policies.

Recent U.S. experience also illustrates an important drawback in applying the optimal currency area idea to actual currency areas. The dollar's appreciation has distributed demand unevenly among sectors of the U.S. economy, hurting agriculture and some manufacturing industries. As long as shocks fall differentially on sectors between which productive factors are temporarily immobile, there can be no presumption that the United States, the EMS, or Japan is an optimal currency area. When the demand for one sector's output rises, other sectors linked to it by a common currency may suffer as a result of the same currency appreciation that stabilizes aggregate employment at home and stimulates growth abroad. The associated distributional and adjustment 
costs are far from trivial and must be weighed against any aggregate benefits in evaluating the desirability of floating rates.

These costs underlie the recent focus on the cost of exchange rate misalignments. Real exchange rate cycles of long and uncertain duration, such as those evident in figure 1, can cause the economy to incur unemployment and relocation costs repeatedly, as productive factors migrate out of the sectors that are depressed at the time. Further, sustained appreciation inevitably gives rise to increased demands for protection in the tradable-goods sector. Capitulation to these demands invites foreign retaliation, and so leads to a structure of trade barriers that is difficult to remove later without extensive multilateral negotiation. Current congressional moves to protect import-competing U.S. industries illustrate the dangers of protracted swings in competitiveness.

To be effective, a policy response to a known goods-market shock must consider adjustment costs and the dangers of protectionism. But it must also take into account the shock's permanence-which is likely to be unknown. The case for a monetary rather than an exchange rate response to a goods-market shock is quite weak when the shock is permanent. In this case, as was shown by the model in the previous section, monetary policy can only slow a necessary real exchange rate adjustment that will eventually be brought about by price-level changes if the nominal exchange rate is pegged. Only when it is known that a particular goods-market shock will be reversed within several years is there a case for resisting its real exchange rate effect through monetary policy so that excessive relocation costs are avoided. Discussions of misalignment therefore presuppose a divergence of the real exchange rate from some "fundamental" equilibrium level that is in some sense sustainable in the long run.

John Williamson has defined this "fundamental" level of the real exchange rate as "that which is expected to generate a current account surplus or deficit equal to the underlying capital flow over the cycle, given that the country is pursuing 'internal balance' as best it can and not restricting trade for balance of payments reasons." ${ }_{29}$ An important addendum to this definition concerns the composition of national saving. The situation described above is not one of "fundamental equilibrium" unless the government budget is also balanced over the cycle.

Misalignments such as the dollar overvaluation of the early 1970s

29. Williamson, The Exchange Rate System, p. 14. 
certainly arose under fixed rates. But with flexible rates the frequency of real exchange rate cycles has increased, as has the frequency with which the costs of misalignment have been incurred. Recent suggestions that central banks limit the permissible range of exchange rate fluctuations over the medium term are motivated in part by the hope that increased official intervention will reduce the amplitude and frequency of misalignments.

The diagnosis of exchange rate misalignment raises problems familar from the discussion of automatic stabilizers in open economies. Misalignments may be difficult to identify in practice because of uncertainty regarding private expenditure patterns and the size of the "underlying capital flow." ${ }^{30}$ There is no necessity for these factors to change gradually over time, and if they do not, there is a case for allowing a misalignment to emerge rather than pegging the exchange rate. The reasoning comes from the discussion of optimum currency areas: in the face of substantial but unobservable goods-market disturbances, there may be a trade-off between intersectoral distress and the attainment of output and price stability for the economy as a whole. If a goods-market shock is transitory, there is a case for pegging the rate, but the permanence of a given shock is generally unknown. Only when a disturbance is known to originate in asset markets is it clearly correct to peg.

The same point may be looked at another way. In the absence of capital controls, the central bank can target the real exchange rate in the short run only by devoting monetary policy to that end. This may prevent short-run misalignment, but it will not guarantee that the policy mix is always appropriate for attaining the goals of internal and external balance. The reason for this is that there are many policy settings consistent with a given "fundamental" exchange rate. It makes little sense to choose a real exchange rate target on the basis of its consistency with internal and external balance while pursuing a policy mix that attains neither of these objectives.

In figure 5, the II schedule shows levels of fiscal and monetary ease consistent with internal balance in the short term; it is downward sloping, and its slope depends on policymakers' preferences regarding future inflation. The $E E$ or external balance schedule shows policy combina-

30. Empirical methodologies for measuring misalignments are proposed and implemented in Williamson, The Exchange Rate System, and in Artus and Knight, "Issues." 
Figure 5. Internal and External Balance

Fiscal expansion

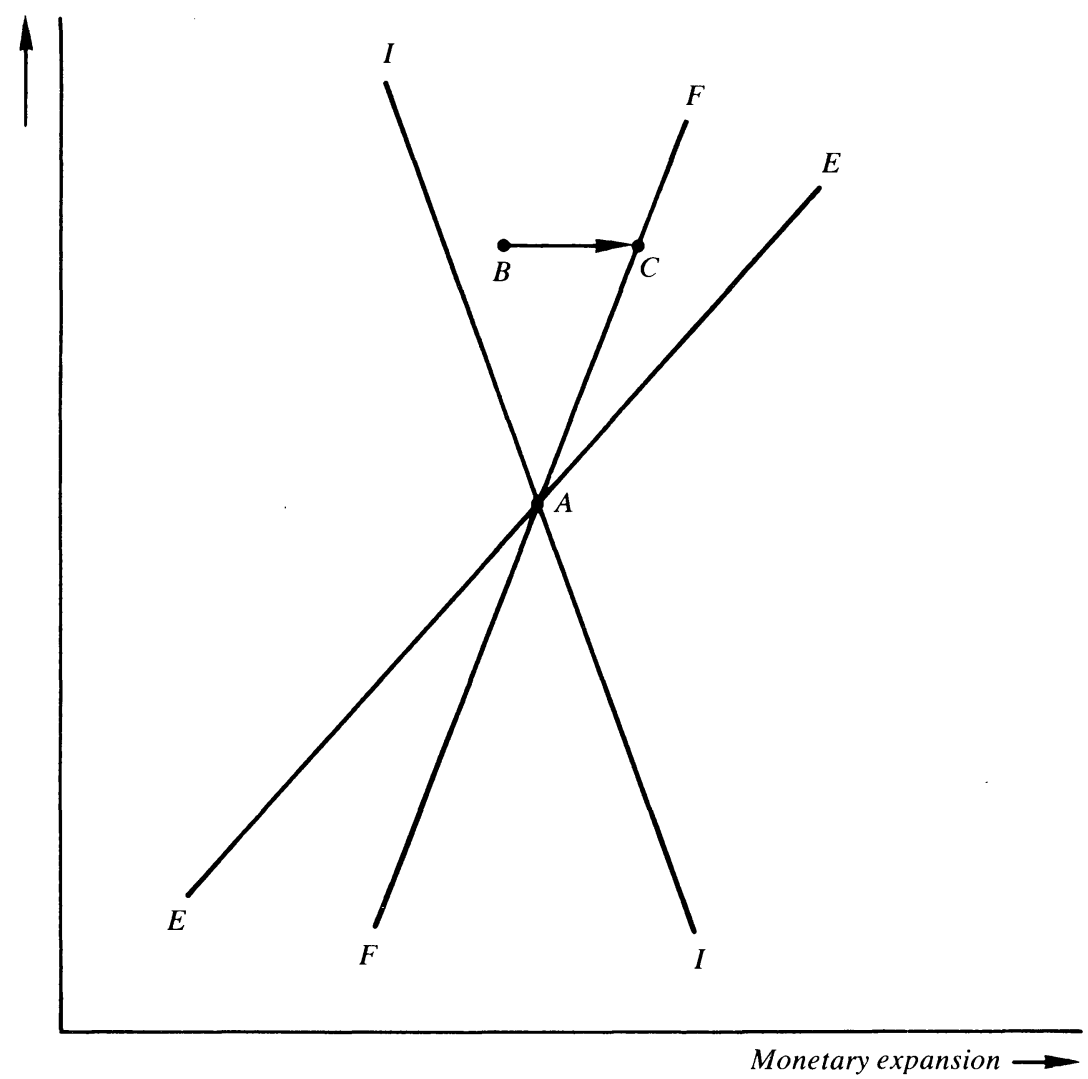

tions that hold the current account constant at the level of the " underlying capital flow" determined by saving propensities and investment opportunities. It is upward sloping because easy money is assumed to improve the current account through an export-led expansion while fiscal ease crowds out net export demand. If the current account is an increasing function of the real exchange rate $Q$ and a decreasing function of domestic expenditure $Z$, then $Q$ must rise, spurring net exports, as policy becomes more expansionary along $E E$ and $Z$ rises. It follows that the upwardsloping locus $F F$ along which the exchange rate is constant at its "fundamental" level is steeper than the external balance schedule $E E$. 
For an economy initially at point $B$, near internal balance but with an external deficit, there are many combinations of policy change that attain $F F$ and eliminate the misalignment in the short run. But the desired point $A$ is reached only through a mild monetary expansion and a substantial fiscal contraction. Bringing the exchange rate down entirely through monetary expansion-which is what would occur with an exchange rate target-moves the economy closer to external balance (point $C$ ) but has inflationary consequences that will, over the longer term, erode any real depreciation so achieved.

Attempts to prevent misalignments through monetary policy alone may therefore encounter serious pitfalls. But a fiscal-monetary mix that attains point $A$ in the diagram will also be problematic if it results in a structural fiscal imbalance. Even when it is known that a particular shock originates in the goods market, it will sometimes be preferable from a longer run perspective to let the exchange rate, rather than fiscal policy, adjust. As the current U.S. situation shows, a fiscal stance may be hard to reverse once it has been legislated into existence. A further complication is that one country's attempt to achieve internal and external balance may exacerbate the misalignments perceived by foreign authorities. The effective elimination of international imbalances requires international coordination of both monetary and fiscal policies.

\section{Recent Exchange Rate Movements: Disturbances and Policies}

A conclusion of the preceding section was that any case for flexible exchange rates is stronger when goods-market disturbances tend to outweigh asset-market disturbances in importance. Unfortunately, the cause of a particular exchange rate movement is often difficult to determine empirically, even long after the fact. Standard empirical exchange rate equations, which correlate rate movements with contemporaneous movements in money supplies, incomes, interest rates, and other variables, are of little help in this regard because their right-hand side variables are generally endogenous. In addition, the instability and poor out-of-sample fit of these equations are notorious. ${ }^{31} \mathrm{I}$ therefore turn

31. See Richard A. Meese and Kenneth S. Rogoff, "Empirical Exchange Rate Models of the Seventies: Do They Fit Out-of-Sample?'” Journal of International Economics, vol. 14 (February 1983), pp. 3-24. 
in this section to some informal methods of assessing the roles of goodsmarket and asset-market disturbances in recent exchange rate experience. The evidence I review suggests that goods-market shocks have played an important role, particularly since the early $1980 \mathrm{~s}$. The evidence also suggests that U.S. macroeconomic policy contributed significantly to both the dollar's depreciation between 1976 and 1979 and its appreciation since.

THE ROLE OF MONETARY POLICY

Dramatic shifts in monetary policies both in the United States and abroad have characterized the years since 1979. The effects of these shifts on exchange rates are difficult to quantify, but it seems likely that perceptions about future U.S. monetary policy have played a key role since the mid-1970s, particularly in contributing to the dollar's appreciation in 1979-82 and its earlier sharp depreciation in 1977-79.

In the fall of 1979, the dollar, having depreciated in real terms by roughly 10 percent relative to its 1976 peak, was widely regarded as undervalued. In retrospect, monetary factors appear to have been critical in causing the dollar's nominal depreciation over this period. Despite accelerating domestic inflation, the Federal Reserve exceeded its announced M1 growth targets in 1977, 1978, and 1979. As Robert Solomon observes, by the second half of 1979, " There was some question whether the Federal Reserve was losing control." 32 One piece of evidence in favor of assigning money a large role in the 1977-79 events is that the dollar's nominal depreciation exceeded its real depreciation. On this view, the real depreciation that did occur was primarily temporary, the result of sluggishness in domestic prices. From January 1977 to September 1978, U.S. nominal interest rates rose sharply, while German and Japanese rates declined, another indication that the dollar's depreciation over that period was being fueled by inflationary expectations. Restrictive measures taken by the United States in October 1978 raised nominal dollar interest rates further, but also affected expectations and temporarily arrested the dollar's slide.

Monetary growth abroad, notably in Germany and Japan, accelerated sharply between 1977 and 1978. But the acceleration was largely a

32. See Solomon, The International Monetary System, p. 352. 
response to the dollar's depreciation and occurred against a background of falling consumer price inflation. In those two years, foreign central banks acquired a massive $\$ 70.4$ billion in claims on the United States through foreign exchange intervention. Attempts were made to sterilize these dollar purchases, but their net effect on foreign money supplies was still expansionary. ${ }^{33}$

At the time, the emergence of record current account imbalances-a U.S. deficit, German and Japanese surpluses-was viewed as an important factor in explaining the dollar's precipitous fall (see table 2). The significance that was then attached to current account developments appears now to have been excessive. Sharp increases in U.S. investment in 1977 and 1978 more than offset the current account's influence on U.S. wealth. Moreover, purchases of dollar assets by foreign central banks may have offset any portfolio-balance effects of the U.S. deficit on the dollar's value. It has been suggested that the primary exchange rate effect of the 1977-78 current account imbalances was a "news" effect. According to this view, the market interpreted the changed configuration of external balances as evidence of a demand shift away from U.S. goods requiring a real depreciation of the dollar. ${ }^{34}$

The October 1979 change in Federal Reserve operating procedures, which increased the central bank's emphasis on monetary targets at the expense of interest rate targets, appears to have signaled a turning point in market expectations about the future course of U.S. monetary policy.

33. For a detailed discussion of German and Japanese intervention in this period, see Victor Argy, "Exchange Rate Management in Theory and Practice," Studies in International Finance 50 (Princeton University, International Finance Section, October 1982). In Obstfeld, "Exchange Rates," I estimate that the Bundesbank sterilized 86 percent of its foreign exchange intervention in the period from February 1975 to March 1979.

34. See Michael Mussa, "The Role of the Current Account in Exchange Rate Dynamics" (University of Chicago, Graduate School of Business, June 1980); and Peter Hooper and John Morton, "Fluctuations in the Dollar: A Model of Nominal and Real Exchange Rate Determination," Journal of International Money and Finance, vol. 1 (April 1982), pp. 39-56. Empirical tests supporting the proposition that current account news is important are reported in Rudiger Dornbusch, "Exchange Rate Economics: Where Do We Stand?" BPEA, 1:1980, pp. 143-85. For further results, see Stephen S. Golub, "Testing for the Effect of Current-Account 'News' on Exchange Rates: A Critique," Economics Letters, vol. 7, no. 3 (1981), pp. 273-79. As always, there are stories other than the one told in the text that might explain a positive correlation between unexpected current account deficits and currency depreciation. One possibility is based on a fiscal reaction function: the expectation of a future fiscal contraction to restore current account balance would also have caused a depreciation of the dollar. 
The dollar's real depreciation from its 1976 level came to an end during 1980. A sharp slowdown in U.S. monetary growth from the fourth quarter of 1980 to the fourth quarter of 1981, together with the election of a Republican administration believed to be committed to disinflation, lent credibility to the announced new course for monetary policy. ${ }^{35}$ In late 1980 the dollar entered its recent phase of appreciation as U.S. interest rates surged above interest rates in Germany and Japan.

As was noted earlier in the review of recent macroeconomic developments, the reduction in average annual U.S. monetary growth since 1979 has not been large. However, it is not only current money, but also anticipated money, that influences today's exchange rate. The October 1979 changes may well have led to an extreme downward revision of money growth expected to occur in the future. Evidence on the link between monetary announcements and subsequent changes in asset prices is consistent with the hypothesis that Federal Reserve monetary targets gained credibility as a result of the October 1979 change in operating procedures. ${ }^{36}$

Against the backdrop of a weakening dollar, the Federal Reserve announced in July 1985, after two quarters of surprisingly rapid M1 growth, an upward revision and rebasing of the monetary targets it had set in February. A previous midyear change had occurred in July 1983, but had no dramatic effect on the dollar's value. At this writing it is unclear whether the Federal Reserve's recent change will lead to further depreciation.

\section{AGGREGATE DEMAND AND THE DOLLAR'S APPRECIATION IN}

THE 1980S

As already noted earlier, the recovery from the $1980-82$ recession has been characterized by widely differing growth rates among OECD

35. The Broaddus-Goodfriend effective M1 measure grew at a rate of only 2.4 percent over this period, compared with a regulation-adjusted target growth range of 3.5 to 6 percent. See Broaddus and Goodfriend, "Base Drift."

36. For recent evidence, see John Huizinga and Leonardo Leiderman, "Interest Rates, Money Supply Announcements and Monetary Base Announcements" (University of Chicago, Graduate School of Business, August 1985). For an earlier review and extension of the literature on monetary announcements, see Bradford Cornell, "The Money Supply Announcements Puzzle: Review and Interpretation," American Economic Review, vol. 73 (September 1983), pp. 644-57. 
countries. Further, there have been significant differences in national fiscal stances. These discrepancies provide a possible clue to the extent of the dollar's real and nominal appreciation in the 1980s. As was observed earlier, shifting demands for national outputs call for changes in real exchange rates, changes that are accommodated in turn through changes in nominal exchange rates and national output prices. Is the influence of aggregate demand movements of any empirical importance in determining real exchange rates? The theoretical model set out earlier suggests that goods-market disturbances have made a significant contribution to the dollar's recent real appreciation.

Equation 2, reproduced below, shows the relation between real appreciation in the medium term and permanent growth in the autonomous component of aggregate demand:

$$
q=\frac{\sigma g^{*}-\sigma^{*} g}{\delta^{*} \sigma+\delta \sigma^{*}}
$$

If it is assumed for simplicity that $\sigma=\sigma^{*}$, the impacts of $g$ and $g^{*}$ on long-run $q$ depend only on the sum $\delta+\delta^{*}$ of aggregate demand elasticities with respect to the real exchange rate. In that case, $q=$ $\left(g^{*}-g\right) /\left(\delta+\delta^{*}\right)$.

The elasticities $\delta$ and $\delta^{*}$ depend in part on price elasticities of import and export demand, which may be derived from empirical trade equations. Let $Y^{d}$ be the level (rather than the logarithm) of real aggregate demand for domestic output, $A$ domestic absorption, $X$ the level of exports, $M$ the level of imports, and $Q$ the level of the real exchange rate. Then $Y^{d}$ is given by:

$$
Y^{d}=A+X-Q M,
$$

and $\delta$ equals $\left(Q / Y^{d}\right) \partial Y^{d} / \partial Q$. If $\epsilon_{X}$ is the price elasticity of export demand $(Q / X) \partial X / \partial Q, \chi_{X}$ the export share $X / Y^{d}, \epsilon_{M}$ the import elasticity - $(Q / M) \partial M / \partial Q$, and $\chi_{M}$ the import share $Q M / Y^{d}$, then $\delta$ is given by:

$$
\delta=\chi_{X} \epsilon_{X}+\chi_{M}\left(\epsilon_{M}-1\right),
$$

under the (admittedly arbitrary) assumption that the real exchange rate $Q$ does not directly affect overall absorption. Expression 7 is essentially the well-known Marshall-Lerner-Hirschman condition governing the effect of an exchange rate change on the trade balance.

Reasonably representative values of the export and import shares for 
the United States are $\chi_{X}=\chi_{M}=0.1$. Several estimates of $\epsilon_{X}$ and $\epsilon_{M}$ for U.S. manufactures are available, and the long-run elasticities of 1.67 and 1.06 used in the International Monetary Fund's World Trade Model are fairly typical. ${ }^{37}$ This calibration leads to an elasticity $\delta=0.173$. Because aggregate demand for foreign output can be written as $Y^{* d}=$ $A^{*}+M-(X / Q)$ in a two-region world, the demand elasticity $\delta^{*}$ can be written as:

$$
\delta^{*}=\rho\left(\delta+\chi_{M}-\chi_{X}\right), \quad \rho=\left(Y^{d} / Q Y^{* d}\right) .
$$

Here I take the "rest of the world" to be the six other major industrial countries. This assumption makes $\rho \approx 1$, and, together with the assumptions already made, implies a value of $\delta^{*}=0.173$. The result is the longrun relationship:

$$
q=(1 / 0.346)\left(g^{*}-g\right)=2.89\left(g^{*}-g\right) .
$$

Equation 9 yields a quantitative estimate of the medium-term effect of divergent aggregate demand movements on $q$. For example, it predicts that if the demand for home output rises permanently by 10 percent relative to the demand for foreign output, the real exchange rate will ultimately appreciate by 28.9 percent. The slope coefficient is high both because of the small share of trade in U.S. GNP and because of the moderate price elasticities characteristic of estimated trade equations.

The main drawback to applying relation 9 to actual events is the absence of any reliable empirical data on the autonomous aggregate demand disturbance factors $g$ and $g^{*}$. Changes in the exogenous components of fiscal deficits-as measured, perhaps, by cyclically adjusted deficits-provide a part of the story. The cumulative IMF measure of fiscal impulse discussed in the first section implies a net government demand shift to the United States from other members of the "Big Seven" of $0.042-(-0.032)=0.074$, or 7.4 percent, between 1980 and 1985. On the basis of equation 9, this fiscal change could be responsible for at most a 21.4 percent real dollar appreciation (that is, $2.89 \times 7.4$ percent). But, as was noted earlier, the IMF measure is not additive over time, so this figure probably exaggerates the role of fiscal policy. Peter Hooper obtains a somewhat smaller figure in a simulation of the Federal Reserve Board's Multicountry Model. He finds that U.S. fiscal measures

37. See Artus and Knight, “Issues,” p. 26. 
undertaken in 1981-84 would have caused the dollar to appreciate by about 8 percent in real terms had there been no change in foreign fiscal or monetary policies. ${ }^{38}$

It should be remembered, though, that equation 9 is based on longrun elasticities and does not characterize the economy's equilibrium during the transition to full employment. Short-run values of $\delta$ and $\delta^{*}$ are likely to be significantly smaller than their long-run counterparts, and this may result in real exchange rate overshooting. Possibly offsetting any overshooting effect is the influence of differences between actual outputs and deviations from the trend values assumed in equation 9. These have probably worked in the direction of dampening the dollar's real appreciation.

As equation 6 shows, not only current, but also anticipated, fiscal actions move the real exchange rate. If fiscal stimulus in the United States were expected to rise over time relative to fiscal stimulus abroad, calculations based on observed fiscal positions would understate the fraction of the exchange rate change due to fiscal policy. Blanchard and Summers report 1984 Data Resources, Inc., forecasts of the consolidated U.S. government budget that show declining deficits through $1989 .{ }^{39}$ To the extent that these forecasts represent widely held expectations, they suggest that expected increases in U.S. fiscal stimulus can have played no significant role in exchange rate determination in any recent year.

Aggregate demand developments unconnected with fiscal policies may have been an additional cause of the dollar's rise, however. The high relative growth rate of U.S. real GNP in 1983-84 is difficult to credit in its entirety to fiscal actions taken in the United States since 1981. For example, Hooper finds that fiscal policy contributed a maximum of 2.2 percentage points to GNP growth (in 1983, not 1984), while causing a current account deficit of $\$ 27.9$ billion, just a little over a quarter of the actual deficit of $\$ 101.6$ billion, in $1984 .{ }^{40}$ And the dollar appreciated in real effective terms by 9.2 percent between $1983: 4$ and 1984:4 on the

38. Peter Hooper, "International Repercussions of the U.S. Budget Deficit,' International Finance Discussion Paper 246 (Board of Governors of the Federal Reserve System, September 1984). Similar results are reported by Paul Masson and Adrian BlundellWignall, "Fiscal Policy and the Exchange Rate in the Big Seven: Transmission of U.S. Government Spending Shocks," European Economic Review, vol. 28 (June-July 1985), pp. 11-42.

39. Blanchard and Summers, "Perspectives."

40. Hooper, "International Repercussions." 
basis of relative WPIs. It seems likely, therefore, that autonomous increases in other components of aggregate demand, for example in investment, have played a role in appreciating the dollar. ${ }^{41}$ Tables 1 and 3 show that those industrialized countries that, with the United States, have grown most rapidly in the recovery-Japan and Canada-have also experienced the most marked real currency appreciations. In contrast, all other industrialized countries but Italy suffered real currency depreciations over 1982-84. As the U.S. growth slowdown became apparent in the first half of 1985, the dollar depreciated.

The above reasoning suggests that fiscal policies and aggregate demand shifts have played a significant role in appreciating the dollar in recent years. However, such arguments cannot decisively establish whether the dollar's appreciation has been "justified": at best, they show that the effects of the demand shifts that have occurred are potentially important. Aside from the obvious estimation and data problems, relation 9 , as has already been noted, assumes static expectations. With rational expectations, as in equation 6 , the future paths of $g$ and $g^{*}$ are also important in judging the appropriateness of today's real exchange rate. One factor causing the demand for U.S. goods to decline over time relative to foreign demand is the wealth effect of the U.S. current account deficit. Once again, however, this factor is difficult to quantify. ${ }^{42}$

REAL AND NOMINAL SHOCKS: EVIDENCE FROM STOCK MARKETS AND ANNOUNCEMENTS

One way of getting some idea of the relative importance of goodsmarket and money-market shocks is to study the correlation between

41. Incentives included in the 1981-82 tax changes could have caused the investment boom, but Bosworth presents evidence against this hypothesis. See Barry P. Bosworth, "Taxes and the Investment Recovery," BPEA, 1:1985, pp. 1-38.

42. Krugman presents an empirical argument that the dollar's real value in the spring of 1985 did not reflect reasonable expectations concerning future U.S. current account deficits. See Paul R. Krugman, "Is the Strong Dollar Sustainable?” Working Paper 1644 (National Bureau of Economic Research, June 1985). Similar conclusions are reached by Stephen N. Marris, "The Decline and Fall of the Dollar: Some Policy Issues," BPEA, 1:1985, pp. 237-44, and by Arnold S. Kling, "Anticipatory Capital Flows and the Behavior of the Dollar," International Finance Discussion Paper 261 (Board of Governors of the Federal Reserve System, August 1985). 
changes in nominal exchange rates and in nominal stock prices. If domestic money-market shocks are the dominant source of disturbance, the nominal prices of domestic shares and of foreign exchange should be highly positively correlated. Monetary expansion, for example, causes the nominal prices of stocks and foreign currencies to rise simultaneously. If shocks to aggregate demand or supply are important, however, any positive correlation between stock prices and the price of foreign exchange is likely to be attenuated; the correlation may even be negative.

A positive movement in aggregate demand for domestic goods has a theoretically ambiguous effect on the stock market, but it generally causes the currency to appreciate. The response of stock prices in this case depends on the type of spending disturbance that occurs. A shift in world demand from foreign to domestic goods unambiguously raises domestic stock prices if it is not accompanied by a decline in world saving. An increase in investment demand falling on domestic goods is also likely to be associated with a rise in the stock market. For reasons discussed in detail by Blanchard and Summers, an increase in domestic aggregate demand fueled by a decline in private or public saving has an ambiguous, but probably negative, effect on stock prices. ${ }^{43}$ Increases in domestic aggregate supply have ambiguous exchange rate effects but tend to be associated with rises in stock prices. The likely results of a decline in foreign saving unaccompanied by a shift in tastes toward domestic goods are a depreciation of the home currency and a fall in the home stock market.

Table 6 shows correlations between monthly percentage changes in nominal effective exchange rate and stock price indexes for the United States, Japan, and Germany. Since a rise in one of the exchange rate indexes is a currency appreciation, a negative entry indicates that the domestic currency tends to weaken in the foreign exchange markets when domestic stock prices rise. Over the entire period February 1976 to February 1985 , the correlation is negative but rather small in absolute value for the United States, positive for Japan, and insignificantly negative for Germany. This pattern of correlations suggests that monetary shocks have been most important in the United States, but it indicates substantial goods-market disturbances in the Japanese case.

43. See Blanchard and Summers, "Perspectives." 
Table 6. Correlation between Monthly Percentage Changes in Nominal Effective Exchange Rate and Nominal Stock Market Price Index, 1976-85

\begin{tabular}{lccc}
\hline Country & $\begin{array}{c}\text { February 1976- } \\
\text { February 1985 }\end{array}$ & $\begin{array}{c}\text { February 1976- } \\
\text { December 1981 }\end{array}$ & $\begin{array}{c}\text { January 1982- } \\
\text { February 1985 }\end{array}$ \\
\hline United States & -0.18 & -0.26 & -0.14 \\
Japan & 0.25 & 0.14 & 0.48 \\
Germany & -0.07 & -0.15 & 0.17 \\
\hline
\end{tabular}

Source: Author's calculations, based on exchange rate data from Morgan Guaranty Trust Company of New York, World Financial Markets, and on stock price indexes from OECD, Main Economic Indicators. A rise in an effective exchange rate is an appreciation.

Even so, one would expect a more negative correlation coefficient for the United States if most important disturbances had originated in the domestic money market. ${ }^{44}$

The correlation coefficients turn out to be somewhat unstable over time, however. The discussion above suggested that monetary factors dominated the behavior of the dollar between 1976 and the end of 1981, and that goods-market developments have gained in importance since. Table 6 contains evidence consistent with this proposition. Over the period ending in December 1981, the correlation between percentage increases in the dollar's external value and percentage stock price increases is -0.26 , lower than over the entire sample; but the correlation is $\mathbf{- 0 . 1 4}$ thereafter. For Japan and Germany also, the correlations rise after the end of 1981 . The correlation pattern reported for the second subsample is inconsistent with a dominant role for monetary shocks.

An alternative explanation of a lower correlation between changes in stock and foreign currency prices is a greater incidence of international portfolio shifts in the second period. For example, political instability in Europe could cause a shift out of German and into U.S. assets that might simultaneously appreciate the dollar and push U.S. stock prices upward. However, the correlations between real U.S. and foreign stock prices (that is, nominal stock prices deflated by WPIs) are positive in both subsamples, and more strongly positive in the second. From February 1976 to December 1981 the correlation between percentage changes in

44. Foreign monetary shocks may also weaken any tendency for the domestic currency to depreciate when the domestic stock market rises. If a monetary contraction abroad, for example, causes a home-currency depreciation, a rise in home output, and a rise in the home real interest rate, domestic stock prices may well increase, but need not. If all three countries in table 6 were buffeted only by domestic and foreign monetary shocks, however, one would expect to find a highly negative correlation coefficient for at least one of them. 
U.S. and Japanese real stock prices is 0.20 ; in the period beginning in January 1982 it is 0.32 . The corresponding correlations for Germany are 0.34 and 0.46 . These correlations give little support to explanations of U.S. asset price movements based on "safe haven" considerations.

Evidence on correlations between macroeconomic announcements and subsequent changes in the dollar's foreign exchange value is also consistent with the view that goods-market shocks have played an important role in the recent behavior of exchange rates. Using a multiple regression framework, Gikas Hardouvelis has shown that since October 1979 the dollar has, on average, appreciated after Federal Reserve announcements of unanticipated increases in industrial production, the employment rate, manufacturers' orders for durables, retail sales, and housing starts. (Anticipated values are median forecasts of the variables from the Money Market Services, Inc., survey. $)^{45}$ Quite surprisingly in view of PPP theory, Hardouvelis also finds that the dollar has tended to appreciate after unanticipated increases in the consumer and producer price indexes.

One interpretation of these results is that goods-market shocks have been dominant in the period surveyed by Hardouvelis. For example, in the model set forth above, a positive shock to U.S. aggregate demand causes the price level, output, and the dollar's foreign exchange value to rise simultaneously. A positive monetary shock, in contrast, would cause a rise in output and prices coupled with a currency depreciation.

The evidence on announcements is also consistent with a story in which anticipated future monetary policy plays an important role. These two explanations-real shocks and anticipated monetary policy-are not mutually exclusive. If markets take unanticipated output and pricelevel increases as a signal that monetary policy will become more restrictive in the future, the correlation patterns found by Hardouvelis can emerge.

\section{Would Fixed Rates Have Been Better?}

The apparent importance of goods-market disturbances in explaining recent exchange rate movements suggests that, given the same fiscal

45. Gikas Hardouvelis, "Economic News, Exchange Rates, and Interest Rates" (Columbia University, Barnard College, Department of Economics, February 1985). Personal income is the only activity variable considered whose innovations are associated with subsequent depreciation. 
policies, fixed rates might have exacerbated macroeconomic instability at times. The evidence reviewed in the previous section also suggests that swings in the dollar's real exchange rate since 1976 have been due at least in part to divergent monetary and fiscal policies within the OECD. Such a view raises the question of whether macroeconomic policies would have been less divergent under fixed dollar exchange rates. This section attempts to answer that question.

\section{POLICY CHOICE AND THE EXCHANGE RATE REGIME}

One classic argument against floating rates is the "discipline" argument, which holds that governments, once relieved of the external constraint imposed by a fixed exchange rate, inevitably adopt overexpansionary policies damaging to their neighbors as well as themselves. On a broader reading, the discipline criterion can be interpreted as asking which type of exchange rate regime better promotes policies conducive to international stability. Much of the case for floating rates is based on the principle of monetary autonomy, and while such autonomy is not inconsistent with some degree of discipline, there is a trade-off. A similar tension between individual liberties and the rights of society underlies any legal system.

While the first half of the floating rate period did see an acceleration of inflation in some industrial countries beyond what could be explained by OPEC I and the worldwide reserve explosion of 1971-73, inflation in the industrial countries has dropped dramatically since 1979 . Further, a rapidly depreciating currency has, in a number of instances, forced a dramatic shift in policy; it did so, for example, in the United Kingdom in 1976 and in the United States in 1978-79. On the surface, therefore, the empirical basis for an assertion that floating rates cannot discourage monetary overexpansion appears weak.

In assessing the theoretical relevance of the discipline argument, it is useful to distinguish between monetary discipline and fiscal discipline. On the monetary side, the discipline argument is really an argument for a commodity standard, such as a gold standard. No system of fixed exchange rates based on a fiat reserve currency imposes automatic discipline on the country whose liabilities are held as international reserves. A system with symmetric balance of payments adjustment can discourage monetary expansion by individual countries, but it places no limits on coordinated monetary expansion throughout the world. If a 
system of fixed rates is to impose automatic constraints on worldwide inflation, the world stock of money must be beyond human control. Such a system certainly does impose harsh discipline on worldwide monetary growth, but it represents an extreme sacrifice of monetary autonomy. ${ }^{46}$

It is much less clear how a fixed exchange rate imposes automatic discipline on fiscal policy. Under a fixed rate a higher government deficit that is not monetized leads to capital inflow and, at least for a time, a gain in foreign reserves. Reserve movements therefore impose no discipline on bond-financed fiscal deficits in the short term. If the deficit expands at too rapid a pace for too long, there is a confidence crisis and foreign lending dries up. But this threat is no greater under fixed rates than under floating rates. Floating rates may encourage bond-financed fiscal deficits if policymakers believe they can devalue their nominal debt later through a surprise monetary expansion. A fixed exchange rate precludes this strategy only if surprise devaluations of the currency are impossible.

When the exchange rate is flexible, a growing deficit induces a sharply appreciating currency. Injured sectors of the economy will then generate at least some political pressure for fiscal contraction. Under fixed rates the real appreciation is more gradual, and lender confidence may collapse before internal pressure to moderate the fiscal ease has built up. As current events show, however, the great danger of relying on a real appreciation to moderate fiscal policy is that those hurt are likely to press for protection rather than deficit reduction-particularly if protection appears to be the political path of least resistance. It is sometimes argued that fixed exchange rates would give a government more time to reduce a fiscal deficit before protectionist pressures became irresistible. But since the government created the deficit in the first place, one must ask which of its short-term consequences under fixed rates will induce a change of course.

Bond-financed fiscal expansion raises interest rates and inflation more in the short run under fixed than under floating rates. Are these factors powerful incentives in favor of budget cutting? The U.S. experience of

46. For a recent discussion of the drawbacks of a gold standard, see Richard N. Cooper, "The Gold Standard: Historical Facts and Future Prospects," BPEA, 1:1982, pp. 1-45. With the establishment of the two-tier gold market in March 1968, the dollar in effect became a fiat currency. From the perspective of the United States, the threat that foreign official dollar holders would redeem their dollars for gold remained as an external constraint on dollar creation (until August 15, 1971). But from the perspective of the system as a whole, the automatic limit to money creation by central banks had been abolished. 
the late 1960s does not favor this view. The budget submitted by President Johnson in January 1966 failed to raise taxes to balance increases in military spending. Not until June 1968 was a tax surcharge approved by Congress. Monetary and fiscal contraction helped drive the U.S. economy into recession by the end of 1969 , but the previous expansion had already built considerable inflationary momentum into U.S. prices. Arguably, the failure of the exchange rate system to impose prompt discipline on U.S. fiscal expansion after January 1966 helped set the stage for the unraveling of the system, beginning in early 1971. The breakdown was accompanied by a major protectionist measure, the temporary 10 percent import surcharge imposed by the United States to induce foreign agreement to an exchange rate realignment.

In summary, fixed exchange rate regimes based on fiat reserve currencies can exert automatic monetary discipline on individual countries, but, like floating rates, place no limits on global monetary expansion. And even for individual countries, a depreciating floating rate may discourage excessive money growth. With respect to excessive bondfinanced fiscal deficits, there appears to be no presumption that fixed rates have an advantage over floating rates in promoting restraint.

A broader application of the discipline criterion must focus not just on which exchange rate regime is at an advantage in discouraging overexpansionary policies, but on which can better cope with overcontractionary policies as well. As the fixed rate system gives countries with balance of payments surpluses no strong incentive to expand, it cannot be argued that fixed rates dominate flexible rates on this ground.

The problem of noncooperative international policymaking reflects another aspect of the tension between individual optimization and society's welfare. Concern about noncooperative behavior is not new; the phenomenon of "competitive devaluation" has long been recognized as a problem of the international economic system between the two world wars. Recently, however, attention has focused on the broader problem of macroeconomic policy formulation among interdependent economies.

The example of a unilateral disinflation illustrates the possibility of an inefficient noncooperative outcome. ${ }^{47}$ When a country disinflates, it exports part of its inflation abroad by causing foreign currencies to

47. McKinnon's criticism of U.S. monetary policy between 1980 and mid-1982 can be interpreted as an argument that noncooperative policymaking in the OECD made the recent recession more costly than necessary. See McKinnon, An International Standard. 
depreciate. If foreign authorities resist by a competitive reduction in their own money growth rates, exchange rates do not change, but output falls everywhere. International policy coordination may achieve a path of inflation and output that all countries' policymakers prefer. ${ }^{48}$

If complete policy coordination is impossible, fixed exchange rates could be a desirable second-best solution. Gilles Oudiz and Jeffrey Sachs have argued that the potential gains from coordination are empirically small. ${ }^{49}$ The payoff of fixed rates in terms of improved policy coordination can be no higher than the payoff to optimal policy coordination.

\section{OECD POLICIES AND THE EXCHANGE RATE}

Another way of assessing the incentives embedded in the two exchange rate regimes is to ask if fixed dollar exchange rates would have led to better OECD macroeconomic policies over the last decade. This is a highly speculative enterprise, but plausible hypothetical scenarios seem to point to a negative answer. Given the dollar's status as the principal reserve currency, it is likely that policies and performance since the mid-1970s would have been worse under fixed rates.

Imagine first how the history of the late 1970s unfolds under fixed rates. Foreign central banks that peg their exchange rates to the dollar in 1977-78 acquire even more international reserves than they actually did in those years. The resulting acceleration in monetary growth abroad fuels inflation and possibly encourages stringent controls on capital inflow. ${ }^{50}$ In the short run, however, fixed dollar rates hold hypothetical U.S. inflation below its actual path while simultaneously worsening Japanese and European inflation. If anything, the export of inflation abroad in the short term causes U.S. money to grow more rapidly than it would under a depreciating floating rate. By the time OPEC II hits, inflationary pressures throughout the OECD are intensifying.

48. See, for example, Matthew B. Canzoneri and Jo Anna Gray, "Monetary Policy Games and the Consequences of Non-Cooperative Behavior," International Economic Review, forthcoming; Rogoff, "Can International Monetary Policy Cooperation Be Counterproductive?"; Gilles Oudiz and Jeffrey Sachs, "Macroeconomic Policy Coordination among the Industrial Countries," BPEA, 1:1984, pp. 1-64; and Francesco Giavazzi and Alberto Giovannini, "Monetary Policy Interactions under Managed Exchange Rates" (Columbia University, Graduate School of Business, June 1985).

49. Oudiz and Sachs, "International Policy Coordination."

50. In fact, Germany and Japan, which intervened heavily to support the dollar at the time, did tighten capital controls somewhat. See Argy, Exchange-Rate Management, and Obstfeld, "Exchange Rates." 
There are no automatic incentives for the United States to pursue a more contractionary monetary course under a fixed exchange rate system that insulates the U.S. money supply from balance of payments considerations. Nor is the United States forced to slow its money growth under a scheme, like McKinnon's, in which the United States remains the reserve currency center but must contract its money supply by an amount equal to foreign official dollar purchases. ${ }^{51}$ But under the latter type of system, foreign central banks, acting in concert, can successfully slow world money growth through contractionary domestic credit policies of their own.

A hypothetical replay of more recent events suggests that fixed dollar rates may also fail to prevent a sustained U.S. fiscal expansion. With the rest of the OECD pegging to the dollar, a rising U.S. fiscal deficit necessitates dollar reserve sales by foreign central banks and causes a continuing fall in money supplies abroad. Foreign GNP growth slows, and a fall in price levels abroad relative to the U.S. price level sets off a gradual real appreciation of the dollar. Slower growth could prompt a more expansionary fiscal stance elsewhere in the OECD, but a move to control capital outflow is the more likely response. If enacted, capital account restrictions push U.S. interest rates up even further. Even in the absence of capital controls abroad, U.S. interest rates rise more under a fixed rate than they would under a floating rate. Higher U.S. interest rates may, but need not, discourage government borrowing, and might simply swell the deficit. Their most likely result is increased political pressure for the Federal Reserve to monetize.

Fiscal expansion in the United States exerts upward pressure on the domestic price level, pressure that is greater if the U.S. monetary base automatically expands as foreign central banks lose reserves because a U.S. fiscal deficit then pushes the U.S. money supply upward. This inflationary pressure could lead to a fiscal reversal, but it could also lead to a monetary contraction. Tighter money might force a fiscal reversal

51. See McKinnon, "A New Tripartite Monetary Agreement." The only additional automatic constraint imposed by the McKinnon scheme would be the need for the U.S. government to raise taxes eventually to pay interest on the Federal Reserve's growing obligations to foreign central banks. In a sense, therefore, the problem of excessive monetary expansion under fixed rates can be the problem of excessive fiscal expansion in disguise. For a detailed discussion of the connection between foreign exchange intervention and the government budget constraint, see Maurice Obstfeld, "Speculative Attack and the External Constraint in a Maximizing Model of the Balance of Payments," Canadian Journal of Economics, forthcoming. 
by driving interest rates up even higher. But unless capital flows are restricted, an obstinate U.S. refusal to bring down the deficit-perhaps accompanied by official denials that government deficits affect interest rates-would ultimately induce foreign countries to devalue their currencies against the dollar.

\section{WAGE SETTING AND THE EXCHANGE RATE REGIME}

The process by which wages are set may also depend on the exchange rate regime. As changes in import prices become more frequent, unions may become more aggressive in pressing wage demands, or the pattern of wage indexation may change. In either of these cases, wages can respond to inflation more quickly under floating rates than under fixed rates. The possible endogeneity of wage-setting arrangements must be taken into account in comparisons of macroeconomic performance under different exchange rate regimes. In particular, arguments based on the exchange rate's role as an automatic stabilizer become more complicated once the response of labor market institutions to the policy environment is recognized.

Policymakers' responses to the increased scope for money creation under a float could also affect the wage process. If floating rates free the authorities to engineer surprise inflations, and their propensity to do this is recognized, wage inflation is likely to accelerate. ${ }^{52}$ Alternatively, the scope for accommodating wage demands under floating rates may encourage wage inflation if the government's commitment to price stability is in doubt.

But it is not obvious that policymakers' preferences will always encourage more aggressive wage-setting behavior under floating rates. Kenneth Rogoff provides an example in which wage demands are more moderate under floating rates than under a fixed rate regime in which national central banks cooperate. ${ }^{53}$ In his model, authorities fearful of the real depreciation caused by unilateral inflation under a floating rate

52. Barro and Gordon have described the noncooperative inflationary equilibrium that can result from the strategic interaction of wage setters and the monetary authority. See Robert J. Barro and David B. Gordon, "A Positive Theory of Monetary Policy in a Natural Rate Model," Journal of Political Economy, vol. 91 (August 1983), pp. 589-610.

53. Rogoff, "Can International Monetary Policy Cooperation Be Counterproductive?" 
are less inhibited about causing inflation when they know other governments will follow suit. Wage demands therefore rise in all countries when a fixed rate regime is adopted, and the authorities must accommodate these demands to avoid unemployment. Further, even under a fixed rate a central bank can accommodate excessive wage increases through devaluation. ${ }^{54}$

As a first step in investigating the stability of the wage process across exchange rate regimes, I have estimated reduced-form equations that express wage inflation as a function of lagged wage inflation, lagged unemployment, and lagged inflation in import prices. Table 7 shows estimates for the United States, Germany, Japan, and the United Kingdom over fixed and floating rate periods. The equation estimated is:

$$
\Delta w_{t}=\beta_{0}+\beta_{1} \Delta w_{t-1}+\beta_{2} U_{t-1}+\beta_{3} \Delta p_{t-1}^{I},
$$

where $w$ once again is the logarithm of the nominal wage, $U$ is the unemployment rate, and $p^{I}$ is the logarithm of the import price index.

The results are quite imprecise, particularly for the period ending in 1972 , and most of the equations suffer from some residual autocorrelation. ${ }^{55}$ But a few tentative conclusions can be drawn. For the United States, there is essentially no evidence of instability in the wage-setting process. For Germany the importance of lagged import price changes becomes greater in the floating rate period, but there is no indication of an accelerated response of wages to inflation.

For both Japan and the United Kingdom, however, the coefficient of the lagged wage drops dramatically, while the coefficient of the unemployment rate rises in absolute value. This is consistent with an accelerated response of wages to inflation, but the results are not highly significant and can only be suggestive at this stage.

The main implication of the regressions is that further work must be done. In addition to improving the specification of the wage equations

54. For a formal analysis, see Henrik Horn and Torsten Persson, "Exchange Rate Policy, Wage Formation, and Credibility" (University of Stockholm, Institute for International Economic Studies, December 1984).

55. Recall that the Durbin-Watson statistics reported here are biased toward the value of 2.00. Given the few degrees of freedom allowed by these annual data, it did not seem that sophisticated corrections would produce substantially more reliable results. 
Table 7. Wages, Unemployment, and Import Price Inflation, 1962-84

\begin{tabular}{|c|c|c|c|c|c|}
\hline \multirow{2}{*}{$\begin{array}{c}\text { Country } \\
\text { and } \\
\text { period }\end{array}$} & \multirow[b]{2}{*}{$\begin{array}{c}\text { Lagged } \\
\text { wage }\end{array}$} & \multirow{2}{*}{$\begin{array}{l}\text { Lagged } \\
\text { unemploy- } \\
\text { ment rate }\end{array}$} & \multirow{2}{*}{$\begin{array}{l}\text { Lagged } \\
\text { import } \\
\text { price }\end{array}$} & \multicolumn{2}{|c|}{ Summary statistic } \\
\hline & & & & $\bar{R}^{2}$ & $\begin{array}{l}\text { Durbin- } \\
\text { Watson }\end{array}$ \\
\hline \multicolumn{6}{|l|}{ United States } \\
\hline $1962-72$ & $\begin{array}{c}0.152 \\
(0.295)\end{array}$ & $\begin{array}{c}-1.296 \\
(0.527)\end{array}$ & $\begin{array}{r}-0.117 \\
(0.196)\end{array}$ & 0.52 & 2.54 \\
\hline $1973-84$ & $\begin{array}{c}0.156 \\
(0.252)\end{array}$ & $\begin{array}{c}-2.404 \\
(0.931)\end{array}$ & $\begin{array}{c}0.090 \\
(0.109)\end{array}$ & 0.63 & 2.15 \\
\hline \multicolumn{6}{|l|}{ Germany } \\
\hline $1964-72$ & $\begin{array}{c}-0.145 \\
(0.560)\end{array}$ & $\begin{array}{c}-3.371 \\
(2.739)\end{array}$ & $\begin{array}{c}0.039 \\
(0.520)\end{array}$ & -0.10 & 1.61 \\
\hline $1973-84$ & $\begin{array}{c}-0.361 \\
(0.229)\end{array}$ & $\begin{array}{c}-2.212 \\
(0.494)\end{array}$ & $\begin{array}{c}0.216 \\
(0.108)\end{array}$ & 0.72 & 1.78 \\
\hline \multicolumn{6}{|l|}{ Japan } \\
\hline $1962-72$ & $\begin{array}{c}0.224 \\
(0.356)\end{array}$ & $\begin{array}{c}-2.548 \\
(6.338)\end{array}$ & $\begin{array}{c}0.374 \\
(0.589)\end{array}$ & -0.13 & 1.65 \\
\hline $1973-84$ & $\begin{array}{c}0.015 \\
(0.235)\end{array}$ & $\begin{array}{r}-30.005 \\
(8.719)\end{array}$ & $\begin{array}{c}0.039 \\
(0.105)\end{array}$ & 0.62 & 2.26 \\
\hline \multicolumn{6}{|c|}{ United Kingdom } \\
\hline $1965-72$ & $\begin{array}{c}0.396 \\
(0.661)\end{array}$ & $\begin{array}{c}-0.930 \\
(7.848)\end{array}$ & $\begin{array}{c}0.523 \\
(0.657)\end{array}$ & -0.06 & 1.79 \\
\hline $1973-84$ & $\begin{array}{c}0.022 \\
(0.230)\end{array}$ & $\begin{array}{c}-2.225 \\
(0.886)\end{array}$ & $\begin{array}{c}0.268 \\
(0.159)\end{array}$ & 0.64 & 1.67 \\
\hline
\end{tabular}

Source: Author's calculations. Wages (unit labor costs) and unemployment rates are from OECD, Main Economic Indicators. Import prices are import unit values from United Nations, Yearbook of International Trade Statistics, 1982, vol. 1 (U.N., 1983), and United Nations, Monthly Bulletin of Statistics, several issues.

a. Annual data. The dependent variable is the percentage rate of change in unit labor costs. Numbers in parentheses are standard errors. Unemployment rates are the residuals from a regression on a constant and a linear time trend.

and studying quarterly data, future research should aim to develop more discriminating tests. A finding that the wage process changes after 1972 is not in itself conclusive evidence that the adoption of floating rates caused the change. Observed changes in wage arrangements are likely to have been related also to structural shocks such as the 1973 and 1979 oil crises and to macroeconomic policy choices that were facilitated, but not forced, by floating rates.

Indeed, the recent shift toward a less expansionary macroeconomic posture in Europe has been accompanied by a partial deindexation of wages in some countries. Deindexation may in part be due to growing confidence in the permanence of the EMS. It is an open question whether policy changes alone, unaided by any EMS obligations, could have induced similar modifications in the wage-setting process. 


\section{Volatility and Credibility}

Since the short-term volatility of exchange rates, both in real and in nominal terms, has been one of the most striking features of the float, any general assessment of floating rates must evaluate the costs imposed by volatility. Volatility, which refers to the variability of exchange rate changes over relatively short periods, is to be distinguished from longer term misalignments that develop over several years. Although recent empirical work has found little direct evidence that volatility has adversely affected economic performance, the possibility remains that it has imposed informational costs that are difficult to measure.

Turbulence in international asset markets can occur under both fixed and floating rates, as the events of the early 1970s show. The analysis of optimal currency areas suggests that in response to certain shocks, authorities will have incentives to attempt surprise changes in fixed parities. But fixed exchange rates that are not credibly fixed can lead to disruptions in international and domestic financial markets. Speculative capital movements under unconvincingly fixed rates would push national authorities toward the imposition of costly capital controls. Many of the benefits of credibly fixed exchange rates would be unattainable in practice.

VOLATILITY AND BUBBLES

It is now well understood that short-term volatility is to be expected in a floating rate system, in view of the exchange rate's role as the relative price of two assets. When private international asset trade is unimportant, as was true in the 1950s, a floating exchange rate ensures a balanced current account, and its variability is limited by the variability in import and export demands. Since the return to currency convertibility in late 1958, however, there has been a phenomenal increase in the volume of international asset trade and in the integration of world capital markets. ${ }^{56}$

56. For evidence on international financial integration, see Ralph C. Bryant, "International Financial Intermediation: Underlying Trends and Implications for Government Policies," prepared for the Second International Conference, Institute for Monetary and Economic Studies, Bank of Japan, Tokyo, May 1985; and Maurice Obstfeld, "Capital Mobility in the World Economy: Theory and Measurement," Carnegie-Rochester Conference Series on Public Policy 24, forthcoming. 
Transactions on capital account now dominate exchange rate determination in the short run, and news concerning current or future economic conditions may cause exchange rates to jump by a percentage point or more within a trading day.

In table 8 , the standard deviations of month-to-month percentage changes in some nominal effective exchange rates between 1976 and 1985 are compared with corresponding numbers for wholesale price indexes and indexes of nominal stock market prices. In the United States, Japan, and Germany, effective exchange rates have been about three times as volatile as wholesale price indexes. The greater volatility in exchange rates reflects the fact that currency prices, unlike the prices of many goods entering the WPI, are closely linked to expectations about the future as well as to current market conditions. Sluggish adjustment in goods markets relative to asset markets is another cause of the relatively low variability in goods prices. But it should be noted that even when prices and wages are flexible, nominal exchange rate variability can exceed output price variability when goods-market disturbances predominate. ${ }^{57}$

Comparison of the floating and fixed rate periods reveals a striking increase in real exchange rate volatility for the industrial countries starting in $1973 .{ }^{58}$ Because the post-1973 period has been characterized by a number of major structural shocks as well as the change to floating rates, this observation alone does not prove that nominal exchange rate flexibility inevitably entails increased variability of real exchange rates. But the fact of relatively slow price adjustment in goods and labor markets supports this interpretation of the data.

Table 8 also reveals that exchange rates have been no more variable than stock market prices. Since 1976, the U.S. stock market has been

57. See Obstfeld and Stockman, "Exchange-Rate Dynamics." The relatively low variability of Germany's rate is related to its participation in the EMS and the earlier "snake" arrangements. The yen's value has been almost three times as variable as that of the deutsche mark, while the dollar occupies an intermediate position between these two currencies.

58. See Robert E. Cumby and Maurice Obstfeld, "International Interest Rate and Price Level Linkages under Flexible Exchange Rates: A Review of Recent Evidence,"' in Bilson and Marston, eds., Exchange Rate Theory and Practice, pp. 121-51; Hans Genberg, "Purchasing Power Parity under Fixed and Flexible Exchange Rates," Journal of International Economics, vol. 8 (May 1978), pp. 247-76; and Dornbusch, "Purchasing Power Parity." 
Table 8. Standard Deviations of Monthly Percentage Changes in Wholesale Price Indexes, Nominal Effective Exchange Rates, and Nominal Stock Market Price Indexes, February 1976-February 1985

\begin{tabular}{lccc}
\hline Country & $\begin{array}{c}\text { Wholesale } \\
\text { price } \\
\text { index }\end{array}$ & $\begin{array}{c}\text { Exchange } \\
\text { rate }\end{array}$ & $\begin{array}{c}\text { Stock } \\
\text { market } \\
\text { price }\end{array}$ \\
\hline United States & 0.5 & 1.6 & 3.5 \\
Japan & 0.7 & 2.4 & 2.4 \\
Germany & 0.3 & 0.9 & 2.7 \\
\hline
\end{tabular}

Source: Author's calculations. For the United States and Japan, wholesale price index data are from International Monetary Fund, International Financial Statistics, line 63. For Germany, wholesale price index is the index of producer prices of industrial products in home market sales, from Monthly Report of the Deutsche Bundesbank, table VIII.7. Exchange rate data are from Morgan Guaranty, World Financial Markets; stock price indexes are from OECD, Main Economic Indicators.

more than twice as variable as the exchange rate, while in Germany the standard deviation of stock price movements is three times that of exchange rate movements. In Japan, which has a highly variable exchange rate, the standard deviations are equal. The relative variabilities of exchange rates and share prices show that exchange rate volatility has not been excessive when measured against the behavior of other asset prices. ${ }^{59}$

Has exchange rate volatility been excessive in any absolute sense? There are at least two ways of approaching this question. The first is to search for evidence that volatility has harmed economies with floating rates, in terms of either microeconomic or macroeconomic performance. The second approach asks whether exchange rates are moved in part by economically extraneous information, so that their usefulness in transmitting allocative signals is compromised.

Opponents of floating rates argued before 1973 that the increased uncertainty they entailed would prove harmful to international trade. In

59. Similar calculations reaching the same conclusion are reported by William D. Nordhaus, "Statement," in The Decline of the Dollar, Hearings before the Subcommittee on Foreign Economic Policy of the Committee on Foreign Relations, 95 Cong. 2 sess. (Government Printing Office, 1978), pp. 46-50; Jacob A. Frenkel and Michael L. Mussa, "The Efficiency of Foreign Exchange Markets and Measures of Turbulence," American Economic Review, vol. 70 (May 1980, Papers and Proceedings, 1979), pp. 374-81; Jeffrey H. Bergstrand, "Is Exchange Rate Volatility 'Excessive'?”' Federal Reserve Bank of Boston, New England Economic Review (September-October 1983), pp. 5-14; and Bonnie E. Loopesko, "Notes on Exchange Rate Variability" (Board of Governors of the Federal Reserve System, June 1985). 
a recent survey and extension of the empirical work on this question, Peter Kenen and Dani Rodrik find little evidence that short-run volatility in real exchange rates has hampered international trade-hardly a surprising finding, in view of the slim theoretical case for the proposition tested. ${ }^{60}$ Proponents of floating had argued that forward exchange trading would enable importers and exporters to hedge their risks, and indeed the use of hedging facilities has expanded over the floating rate period. New financial instruments have also been introduced. One such, the foreign exchange option, enables traders to avoid exchange risk even when the timing of their foreign exchange receipts is uncertain.

At the macroeconomic level, concern in the early 1970s focused on the possibility that exchange rate volatility might worsen price performance through asymmetric "ratchet" effects on wages or through "vicious circles" of depreciation and inflation. The ratchet hypothesis holds that nominal wages increase when a currency depreciates but do not fall as readily in response to appreciation. Under these circumstances, increased exchange rate volatility is inflationary, since even temporary depreciations of the currency are built solidly into the structure of wages and prices. In a thorough survey of the evidence, Morris Goldstein finds support neither for the asymmetric wage behavior posited by the ratchet argument nor for any effect of exchange rate variability on inflation. ${ }^{61}$ The vicious circle hypothesis is less susceptible to formal empirical testing, but in retrospect it is hard to find a recent example of an industrial country in which currency depreciation unrelated to domestic monetary actions set off a prolonged inflationary spiral.

Although a distinction has been drawn between volatility and misalignment, it is sometimes argued that volatility may contribute to misalignment over the long run. ${ }^{62}$ An alternative hypothesis is that exchange rate volatility increases when goods-market disturbances occur, because markets have more difficulty forecasting the long-run real exchange rate after a goods-market shock, which may change that rate, than after a money-market shock, which does not. Increased volatility accompanies the process through which the market attempts to learn the nature,

60. See Peter B. Kenen and Dani Rodrik, "Measuring and Analyzing the Effects of Short-Term Volatility in Real Exchange Rates," Working Paper in International Economics G-84-01 (International Finance Section, Princeton University, March 1984).

61. See Goldstein, "The Exchange Rate System."

62. See, for example, Jeffrey R. Shafer and Bonnie E. Loopesko, "Floating Exchange Rates after Ten Years," BPEA, 1:1983, pp. 1-70. 
magnitude, and persistence of the disturbance to foreign exchange market equilibrium.

In sum, there is little direct evidence that exchange rate volatility per se has had a harmful effect on the allocation of resources or on macroeconomic performance. This is not to deny that exchange rate flexibility has altered both the channels through which domestic and foreign disturbances affect the economy and the speed with which those disturbances spread.

It is much more difficult to assess whether extraneous factors have had an important effect on exchange rates. ${ }^{63}$ Studies of stock price and interest rate volatility come to the conclusion that price fluctuations in those asset markets have been "excessive." 64 In view of the close linkages among asset markets, excessive volatility in stock and bond markets is likely to imply excessive exchange rate volatility. Studies of volatility in domestic asset markets are, however, based on a rather stringent set of maintained hypotheses, including the absence of risk premiums. It is therefore difficult to draw unqualified normative conclusions from their results.

Nonetheless, it is remarkable how little success econometricians have had in explaining observed short-term exchange rate movements through news about the economic factors believed on theoretical grounds to be fundamental determinants of exchange rates. For example, Hardouvelis's regressions linking one-day exchange rate changes to an array of economic announcements made on the previous day have extremely low explanatory power (his adjusted $R^{2} \mathrm{~s}$ are almost always well below 10 percent) ${ }^{65}$ While it is of course possible that the residual variance is explained by unobservable fundamentals like preferences, or that a continuously changing economic environment precludes the detection of stable economic relationships, the possibility that irrelevant factors influence short-term exchange rate movements cannot be dismissed. In

63. Dornbusch, among others, has suggested this possibility. See Rudiger Dornbusch, "Flexible Exchange Rates and Interdependence," International Monetary Fund Staff Papers, vol. 30 (March 1983), pp. 3-30.

64. See, for example, Robert J. Shiller, "Do Stock Prices Move Too Much To Be Justified by Subsequent Changes in Dividends?" American Economic Review, vol. 71 (June 1981), pp. 421-36; and Stephen F. LeRoy and Richard D. Porter, "The PresentValue Relation: Tests Based on Implied Variance Bounds," Econometrica, vol. 49 (May 1981), pp. 555-74.

65. Hardouvelis, "Economic News." 
fact, there is no foolproof method of testing for the existence of stationary or convergent bubbles, which induce inexplicable fluctuations of exchange rates around the levels justified in terms of fundamentals.

It may, however, be possible to identify divergent or explosive bubbles. These bubbles involve self-fulfilling destabilizing speculations, in which an explosive exchange rate path is supported entirely by expectations of accelerating exchange rate change. Several empirical studies claim to provide evidence of exploding bubbles in foreign exchange and other asset markets. ${ }^{66}$

The methodology for detecting bubbles can be illustrated through the model developed above. ${ }^{67}$ Equation 6, which gives the long-run real exchange rate as a function of market "fundamentals" alone, is only one possible solution of the model's full-employment equilibrium conditions. As the appendix shows, there are infinitely many alternative solutions, for example:

$$
\begin{aligned}
q_{t}= & \frac{1}{\sigma \sigma^{*}+\delta \sigma^{*}+\delta^{*} \sigma} \sum_{j=0}^{\infty}\left(\frac{\sigma \sigma^{*}}{\sigma \sigma^{*}+\delta \sigma^{*}+\delta^{*} \sigma}\right)^{j}\left(\sigma_{t} g_{t+j}^{*}-\sigma^{*}{ }_{t} g_{t+j}\right) \\
& +k\left(\frac{\sigma \sigma^{*}+\delta \sigma^{*}+\delta^{*} \sigma}{\sigma \sigma^{*}}\right)^{t}
\end{aligned}
$$

where $k$ is any nonzero constant. When $k$ is nonzero, contrary to what is assumed in the fundamentals solution 6 , the evolution of the real exchange rate is influenced, and eventually dominated, by the explosive "bubble" term $\left[\left(\sigma \sigma^{*}+\delta \sigma^{*}+\delta^{*} \sigma\right) / \sigma \sigma^{*}\right]^{t}$. A test that $k$ differs from 0 is a test for the presence of a bubble.

The validity of the test hinges on the validity of the model it assumes.

66. See, for example, Richard A. Meese, "Testing for Bubbles in Exchange Markets: A Case of Sparkling Rates?' Journal of Political Economy, forthcoming; Wing T. Woo, "Speculative Bubbles in the Foreign Exchange Markets," Brookings Discussion Papers in International Economics 13 (Brookings, March 1984); Olivier J. Blanchard and Mark W. Watson, "Bubbles, Rational Expectations, and Financial Markets," in Paul Wachtel, ed., Crises in the Economic and Financial Structure (Lexington Books, 1982), pp. 295-315.

67. This methodology was developed by Robert P. Flood and Peter M. Garber, "Market Fundamentals versus Price-Level Bubbles: The First Tests," Journal of Political Economy, vol. 88 (August 1980), pp. 745-70. Flood and Garber mention the point made below, that bubbles and certain omitted variables are observationally equivalent. See also James D. Hamilton and Charles M. Whiteman, "The Observable Implications of SelfFulfilling Expectations," Journal of Monetary Economics, forthcoming. 
And even when the model is correct, interpretation of the test requires additional identifying assumptions about the nature of market expectations, which are inherently unobservable. To see why, consider how an econometrician might test whether $k=0$ in equation 11 .

Write the autonomous demand shift variable $g_{t}$ as the sum of an observed component $d_{t}$ (for example, the full-employment deficit), and an uncorrelated component $u_{t}$ that the econometrician does not observe. Similarly, let $g_{t}^{*}=d_{t}^{*}+u_{t}^{*}$. Assume for simplicity that the economy is always at full employment, and that the random variables $d_{t}$ and $d_{t}^{*}$ have constant conditional means $d$ and $d^{*}$ that the econometrician knows from past observation. Then equation 11 may be written in the form:

$$
\begin{aligned}
q_{t}= & \left(\frac{\sigma \sigma^{*}}{\sigma \sigma^{*}+\delta \sigma^{*}+\delta^{*} \sigma}\right)\left(\frac{\sigma d^{*}-\sigma^{*} d}{\delta \sigma^{*}+\delta^{*} \sigma}\right) \\
& +\frac{1}{\sigma \sigma^{*}+\delta \sigma^{*}+\delta^{*} \sigma}\left(\sigma d_{t}^{*}-\sigma^{*} d_{t}\right) \\
& +k\left(\frac{\sigma \sigma^{*}+\delta \sigma^{*}+\delta^{*} \sigma}{\sigma \sigma^{*}}\right)^{t}+v_{t},
\end{aligned}
$$

where $v_{t}$ depends on current and expected future values of $u_{t}$ and $u_{t}^{*}$. Now add the crucial stipulation that ${ }_{t} u_{t+j}={ }_{t} u_{t+j}^{*}=0$ for $j>0$. Under this identifying assumption, $v_{t}=\left[1 /\left(\sigma \sigma^{*}+\delta \sigma^{*}+\sigma \delta^{*}\right)\right]\left(\sigma u_{t}^{*}-\sigma^{*} u_{t}\right)$ and nonlinear least squares, applied to equation 12, yields consistent estimates of $\sigma, \sigma^{*}, \delta \sigma^{*}+\delta^{*} \sigma$, and $k$.

Suppose that there are no bubbles $(k=0)$, but that within the sample period, the public expected the mean of the unobservable component of domestic aggregate demand, $u_{t}$, to rise permanently from zero to $c$ at a time $T$ beyond the end of the sample. This might be the result of an expected shift in the investment function that the econometrician cannot detect by fitting vector autoregressions, say, to the available data. The expected upward shift in aggregate demand implies a violation of the identifying assumption concerning the composition of $v_{t}$. But an econometrician who is unaware of this violation will see $q_{t}$ follow a path that looks like a divergent bubble and will falsely conclude that a bubble has occurred.

The expectation of an increase in demand for domestic goods lowers the home real interest rate relative to the foreign rate. But since the 
increase in demand has yet to materialize, there must be a real appreciation of the domestic currency (a fall in $q$ ) today to maintain equilibrium in goods markets. From the real interest rate parity condition, a relatively lower domestic real interest rate implies that people expect a further real appreciation of the domestic currency. As $q$ falls over time until $T$, increasingly crowding out aggregate demand at home, the real domestic interest rate must also fall to offset its effects and maintain equilibrium. The appreciation of the currency will therefore accelerate as time $T$ approaches, just as it does along a divergent bubble path. ${ }^{68}$

Theoretical studies based on optimizing models yield a strong case for ruling out divergent exchange rate bubbles. These studies show that while divergent bubbles may occur in economies with fiat monies where government intervention in money markets is unthinkable, the mere possibility that the central bank will intervene to prevent the currency's price from exploding suffices to preclude them. ${ }^{69}$ How then is one to interpret empirical studies purporting to demonstrate the existence of asset-market bubbles? My own view is that economic theory should inform the interpretation of econometric results. For this reason, an econometrician who sets out to estimate a demand curve and finds that quantity depends positively on price is rightly suspected of having made an invalid identifying assumption. Similarly, econometric results purporting to detect divergent bubbles may be viewed more plausibly as reflecting some model misspecification.

\section{THE BEHAVIOR OF FORWARD EXCHANGE RATES}

Assessments of floating exchange rates often focus on the behavior of forward exchange rates as predictors of future spot rates. In the

68. More formally, when the public expects the unobservable component of aggregate demand to increase to $c$ at time $T$, the fundamentals solution, equation 6 , is given by equation 12 , with $v_{t}=\left[1 /\left(\sigma \sigma^{*}+\delta \sigma^{*}+\delta^{*} \sigma\right)\right]\left(\sigma u_{t}^{*}-\sigma^{*} u_{t}\right)$ and

$$
k=\left[-\sigma^{*} c /\left(\delta \sigma^{*}+\delta^{*} \sigma\right)\right]\left[\sigma \sigma^{*} /\left(\sigma \sigma^{*}+\delta \sigma^{*}+\delta^{*} \sigma\right)\right]^{T} .
$$

Thus, bubble-ridden and bubble-free specifications based on different assumptions about the public's expectations can be observationally equivalent. An econometric finding that $k$ in equation 12 differs from zero may be evidence only that the econometrician has adopted an overly simple view of how expectations were formed over the sample period.

69. See Maurice Obstfeld and Kenneth Rogoff, "Speculative Hyperinflations in Maximizing Models: Can We Rule Them Out?" Journal of Political Economy, vol. 91 (August 1983), pp. 675-87; and Maurice Obstfeld and Kenneth Rogoff, "Ruling Out Divergent Speculative Bubbles," Journal of Monetary Economics, forthcoming. 
Table 9. Nominal Interest Differentials as Predictors of Future Exchange Rate Change, 1975-85

\begin{tabular}{|c|c|c|c|c|}
\hline \multirow{2}{*}{$\begin{array}{c}\text { Bilateral } \\
\text { U.S. dollar } \\
\text { exchange rate }\end{array}$} & \multirow[b]{2}{*}{ Constant } & \multirow[b]{2}{*}{$\begin{array}{c}\text { Interest } \\
\text { differential }\end{array}$} & \multicolumn{2}{|c|}{ Summary statistic } \\
\hline & & & $\bar{R}^{2}$ & $\begin{array}{l}\text { Durbin- } \\
\text { Watson }\end{array}$ \\
\hline \multicolumn{5}{|c|}{ February 1975-January 1985} \\
\hline Japan & $\begin{array}{c}0.113 \\
(0.056)\end{array}$ & $\begin{array}{r}-2.188 \\
(0.985)\end{array}$ & 0.03 & 1.97 \\
\hline France & $\begin{array}{c}-0.092 \\
(0.039)\end{array}$ & $\begin{array}{c}-0.483 \\
(0.773)\end{array}$ & -0.01 & 2.27 \\
\hline Germany & $\begin{array}{c}0.040 \\
(0.071)\end{array}$ & $\begin{array}{c}-1.778 \\
(1.573)\end{array}$ & 0.00 & 2.23 \\
\hline United Kingdom & $\begin{array}{c}-0.102 \\
(0.037)\end{array}$ & $\begin{array}{c}-1.477 \\
(0.875)\end{array}$ & 0.02 & 1.93 \\
\hline \multicolumn{5}{|c|}{ February 1975-December 1979} \\
\hline Japan & $\begin{array}{c}0.122 \\
(0.072)\end{array}$ & $\begin{array}{c}-2.033 \\
(1.366)\end{array}$ & 0.02 & 1.91 \\
\hline France & $\begin{array}{c}0.005 \\
(0.057)\end{array}$ & $\begin{array}{c}-0.422 \\
(1.575)\end{array}$ & -0.02 & 2.75 \\
\hline Germany & $\begin{array}{c}0.038 \\
(0.090)\end{array}$ & $\begin{array}{c}0.747 \\
(2.387)\end{array}$ & -0.02 & 2.68 \\
\hline United Kingdom & $\begin{array}{c}0.024 \\
(0.072)\end{array}$ & $\begin{array}{c}0.976 \\
(1.388)\end{array}$ & -0.01 & 1.87 \\
\hline
\end{tabular}

Source: Author's calculations. Exchange rate data are end-of-month rates from $\mathrm{OECD}$, Main Economic Indicators Interest rates are end-of-month one-month Eurocurrency rates from Morgan Guaranty, World Financial Markets.

a. Monthly data. The dependent variable is the percentage change in the bilateral exchange rate expressed as U.S. dollars per units of foreign currency and is regressed against the previous month's interest differential between Eurodollar deposits and Euro-deposits of the foreign currency. Standard errors are in parentheses.

Eurocurrency markets forward exchange premiums equal nominal interest differentials, so a test of the forward premium's predictive efficiency is a test of the interest parity condition, a building block of many exchange rate models. As is also the case in U.S. bond markets, forward premiums have been biased predictors of future exchange rate movements. ${ }^{70}$ This is illustrated in table 9 , where one-month percentage depreciation rates of the dollar against the yen, deutsche mark, franc, and pound are regressed against the previous month's differential between the one-month Eurodollar deposit rate and the one-month rate on the corresponding foreign Eurocurrency. Over the entire period from

70. See Robert J. Shiller, John Y. Campbell, and Kermit L. Schoenholtz, "Forward Rates and Future Policy: Interpreting the Term Structure of Interest Rates," BPEA, $1: 1983,173-217$. 
February 1975 to January 1985, forward premiums mispredicted the subsequent direction of change of all the exchange rates examined. ${ }^{71}$

These results do not necessarily imply that foreign exchange markets have in some sense performed poorly. In a world of risk-averse investors, time-varying risk premiums may drive a wedge between forward premiums and the corresponding expected exchange rate changes. Empirical attempts to explain foreign-exchange risk premiums have not been very successful, however. ${ }^{72}$

Another problem in interpreting results like those in table 9 is the "peso problem," first noted in studies of the biased forecasting performance of Mexican peso futures prior to the August 1976 devaluation of the peso..$^{73}$ The problem is quite similar to the one that arises in attempts to detect bubbles. Suppose the market expected some major event that failed to materialize in the sample. Then econometric tests based on the sample will lead to rejection of interest parity unless the sample contains many similar episodes in which the public was on average correct.

The most likely explanation of the results in table 9 is that the dollar was swept upward after 1979 by a succession of shocks that the public did not expect and then regarded as partially temporary after they occurred. Estimates over 1975-79, also reported in table 9, show that the one-month forward premium did not mispredict the direction of subsequent movements in the dollar-deutsche mark and dollar-pound rates. However, the high Durbin-Watson statistic for the dollar-deutsche mark regression is evidence against the interest parity hypothesis.

71. Similar results are reported by Cumby and Obstfeld, "International Interest Rate and Price Level Linkages"; Robert J. Hodrick and Sanjay Srivastava, "The Covariance of Risk Premiums and Expected Future Spot Exchange Rates"' (Northwestern University, Kellogg Graduate School of Management, March 1984); and Paul Boothe and David Longworth, "Foreign Exchange Market Efficiency Tests: Implications of Recent Empirical Findings" (University of Alberta, Department of Economics, June 1985).

72. See, for example, Lars Peter Hansen and Robert J. Hodrick, "Risk Averse Speculation in the Forward Foreign Exchange Market: An Econometric Analysis of Linear Models," in Jacob A. Frenkel, ed., Exchange Rates and International Macroeconomics (University of Chicago Press, 1983), pp. 113-42; Jeffrey A. Frankel, "In Search of the Exchange Risk Premium: A Six-Currency Test Assuming Mean-Variance Optimization," Journal of International Money and Finance, vol. 1 (December 1982), pp. 255-74; and Robert E. Cumby, "Is it Risk? Explaining Deviations from Interest Parity" (New York University, Graduate School of Business Administration, October 1985).

73. See Kenneth Rogoff, "Essays on Expectations and Exchange-Rate Volatility" (Ph.D. dissertation, Massachusetts Institute of Technology, 1979); and William S. Krasker, "The 'Peso Problem' in Testing the Efficiency of Forward Exchange Markets,' Journal of Monetary Economics, vol. 6 (April 1980), pp. 269-76. 
One finding that is beyond dispute is the low explanatory power of the regressions in table 9. To a first approximation, forward premiums provide no information useful for predicting future exchange rate movements. This is consistent with the view that most variation in floating exchange rates has been caused by unanticipated events.

\section{LIMITING EXCHANGE RATE FLEXIBILITY: THE ROLE OF CREDIBILITY}

Several plans to reform the exchange rate system have been put forward in the hope of limiting volatility and improving the functioning of the system in general. At one extreme, McKinnon has suggested that the United States, Japan, and Germany enter into a tripartite agreement to peg their mutual exchange rates and regulate the growth of their combined money supplies. In contrast, Williamson has suggested that authorities direct monetary policy to "discourage" exchange rate movements beyond announced but adjustable target zones. ${ }^{74} \mathrm{~A}$ major problem with these proposals, emphasized above, is that the use of monetary policy to manage the exchange rate is the appropriate response to a disturbance only in special circumstances. Attempts to use monetary policy to counteract real shocks can significantly worsen macroeconomic performance, particularly when those shocks are permanent. ${ }^{75}$

Most proponents of reform recognize that goods-market shocks will sometimes require adjustments of fixed rates or alterations of target zones. Such changes, however, call into question the credibility of the authorities' commitment to stabilize the exchange rate; the resulting market skepticism may reduce many of the benefits promised by heavier management of exchange rates. Realistic discussions of exchange rate reform therefore should compare flexible rates to a system of exchange rate targets that are not fully credible.

When exchange rates are fixed but devaluations are possible, private international capital flows become more volatile than they would be were it possible for the authorities to commit to an unalterable rate. Typically, parity changes will not occur until some time after they become necessary. And they will usually be forced by massive sales of

74. See McKinnon, An International Standard, and Williamson, The Exchange Rate System.

75. The discussion in McKinnon, An International Standard, focuses exclusively on shocks that operate through the money market. 
the weak currency in the foreign exchange market. The circumstances leading to the 1973 breakup of the fixed rate system-a decline in U.S. competitiveness, followed by a series of violent speculative attacksillustrate the type of problem that would in all likelihood recur.

Consider the example of a sudden and permanent fall in demand for U.S. exports. A floating dollar would depreciate to partially offset the effect of the demand shift on the exporting sector. But a fixed dollar would afford no such offset to the fall in export demand, and severe excess capacity in the export sector would persist until nominal export prices had fallen sufficiently to restore competitiveness. Once it had become evident that a permanent deterioration in export demand had occurred, the United States would have a strong incentive to hasten the adjustment process by devaluing, as in 1971. Since the permanence of a given shock may be impossible to ascertain ex ante, unusually large trade deficits could trigger speculative capital flows even when such deficits were caused by purely transitory shifts in expenditure patterns.

Speculative attacks are not a necessary feature of fixed rate systems, and they would not occur if authorities could credibly renounce parity changes and commit themselves to macroeconomic policies consistent with their promise. But these idealized conditions can never be met in practice. Situations will inevitably arise in which the central bank has an incentive to break the rules "just once," but individual asset holders will be able to guard against this contingency at low personal cost. In this environment speculative attacks will sometimes occur. If the market believes that the policy response to an attack will be an immediate parity change, then balance of payments crises take on the character of bank runs. Purely self-fulfilling attacks therefore become possible, and they provide an example of an asset-market bubble that may occur under (unconvincingly) fixed rates. ${ }^{76}$

Under a target zone arrangement the potential for crisis is less severe. But if the notion of a target zone is to have any content, there will be some occasions on which the central bank takes a stand against exchange

76. The argument leading to this conclusion is given in Maurice Obstfeld, "Rational and Self-fulfilling Balance-of-Payments Crises," American Economic Review, forthcoming. Rational speculative attacks were first analyzed in Stephen W. Salant and Dale W. Henderson, "Market Anticipations of Government Policies and the Price of Gold," Journal of Political Economy, vol. 86 (August 1978), pp. 627-48. The idea was applied to the foreign exchange market by Paul R. Krugman in "A Model of Balance-of-Payments Crises," Journal of Money, Credit and Banking, vol. 11 (August 1979), pp. 311-25. 
rate movements it views as unwarranted. Disagreement between the markets and the authorities in these circumstances would entail massive reserve movements harmful to financial stability.

Recurring crises of this type might lead to the widespread use of capital controls, as in the years before 1973. Within the EMS, France and Italy have maintained strict controls to reduce the scope for sudden reserve losses. ${ }^{77}$ Capital controls are extremely costly to enforce, and, like trade restrictions, they lower private welfare by preventing mutually beneficial trades, in this case intertemporal consumption trades and trades of risks between countries. Further, capital controls may lead firms to distort production decisions so as to exploit trade credit facilities. It is sometimes argued that capital flows behave perversely under a floating rate because monetary contraction may cause both a current account deficit (that is, foreign borrowing) and a fall in the profitability of domestic investment. However, this point is not entirely convincing. Monetary contraction leads also to a temporary fall in national income, and it makes sense for individuals to smooth their consumption levels through borrowing.

Extreme illustrations of the credibility problem come from the experiences of Argentina, Chile, and Uruguay, which pegged their exchange rates to the dollar in the late 1970s as part of broad programs of disinflation and liberalization. These programs coincided with massive currency misalignments, and it is likely that expectations of devaluation, feeding into wage settlements, contributed to the real currency appreciation that occurred, particularly in Argentina. ${ }^{78}$ None of these countries has been able to maintain its preannounced exchange rate targets.

77. Evidence of capital controls within the EMS is presented in Francesco Giavazzi and Marco Pagano, "Capital Controls and the European Monetary System" (University of Venice, Department of Economics, November 1984); and in Kenneth Rogoff, "Can Exchange Rate Predictability Be Achieved without Monetary Convergence? Evidence from the EMS," European Economic Review, vol. 28 (June-July 1985), pp. 93-115.

78. See, for example, Guillermo A. Calvo, "Trying to Stabilize: Some Theoretical Reflections Based on the Case of Argentina," in Pedro Aspe Armella, Rudiger Dornbusch, and Maurice Obstfeld, eds., Financial Policies and the World Capital Market: The Problem of Latin American Countries (University of Chicago Press, 1983), pp. 199-216; Robert E. Cumby and Sweder van Wijnbergen, "Fiscal Policy and Speculative Runs on the Central Bank under a Crawling Peg Exchange Rate Regime: Argentina, 1979-1981" (New York University, Graduate School of Business Administration, 1983); Marianne Baxter, "The Role of Expectations in Stabilization Policy," Journal of Monetary Economics, vol. 15 (May 1985), pp. 343-62; and Vittorio Corbo, Jaime de Melo, and James Tybout, "What Went Wrong with the Recent Reforms in the Southern Cone," Discussion Paper (World Bank, July 1985), forthcoming in Economic Development and Cultural Change. 
An evaluation of alternatives to floating rates must consider market confidence in the durability of the alternatives. Given the comparative disadvantage of fixed rates in the face of certain disturbances, the credibility problem is likely to arise under any arrangements limiting exchange rate flexibility. It is therefore an open question whether such arrangements would be stable in the absence of pervasive capital controls.

\section{Conclusions}

A review of the experience with floating rates reveals an exchange rate system with a number of weaknesses, including a high sensitivity of real exchange rates to purely nominal shocks, an absence of automatic constraints on international liquidity creation, substantial unexplained volatility of exchange rates in the short run, and a tendency to allow protracted swings in competitiveness over the medium term. Yet it is unclear that the alternative systems that have been proposed, such as a return to fixed rates, would be better. Fixed rates would certainly limit exchange rate volatility and probably reduce the frequency of misalignments, but would require periodic discrete adjustment in the face of large persistent shocks to goods markets. The need for periodic readjustment would call into question the credibility of existing parities, and possibly result in speculative attacks and substantial volatility in nominal and real rates of interest. Further, the system would not have the advantage of limiting worldwide liquidity unless reserve-currency centers were required to peg the price of some commodity, such as gold. Under a dollar standard, for example, speculative capital movements could lead to an explosion in the world money supply, as occurred in 1971-73, or to a sharp contraction. Widespread capital controls, difficult to enforce and costly in welfare terms, would be the most likely response to capital account instability.

In light of these drawbacks of a fixed rate regime, the strengths of the present system deserve emphasis. While the current arrangements do not impose automatic monetary discipline or insulate economies from most external shocks, governments can manage domestic money supplies without resort to capital controls, and they can choose trend inflation rates. Floating rates are also at an advantage relative to fixed 
rates in promoting rapid adjustment to goods-market disturbances requiring real exchange rate realignment. Of course, this is not seen as a benefit by sectors of the economy that are hurt by an exchange rate change, and adjustment assistance may be in order in some cases.

Macroeconomic policies have certainly been inappropriate at times, but in these cases it is the policies rather than the exchange rate that is to blame. If a successful exchange rate system is one that would invariably induce national authorities to follow responsible and mutually consistent policies, then the present system is a failure. But it is difficult to think of a system that would succeed when judged by that criterion. In particular, a system of fixed exchange rates would probably not have prevented the emergence of the international fiscal imbalances that are in significant measure responsible for the dollar's real appreciation and that may threaten international financial stability further down the road. Recent protectionist pressures, which are widely ascribed to the dollar's strength in the foreign exchange market, would in all likelihood have emerged eventually under fixed rates in the absence of a reduction in the U.S. government deficit.

There is no doubt that the current system's performance would be improved by more extensive consultation and coordination of policies within the OECD. Current attempts to institutionalize a multilateral approach to policy formation should therefore be pursued. But it is difficult to make a strong case that greater fixity of exchange rates is either feasible or desirable.

\section{APPENDIX}

\section{Two-Region Exchange Rate Model}

THIS APPENDIX provides further details on the theoretical two-region exchange rate model used in the second section above. First, the model's full-employment equilibrium under floating exchange rates is derived. Second, a diagram showing the model's short-run equilibrium under floating rates is developed and used to establish some of the assertions made in the text. Similar techniques may be used to solve the fixed rate version of the model, so a discussion of the fixed rate case is omitted. 


\section{Full-Employment Equilibrium with Rational Expectations}

To solve for the model's full-employment equilibrium, note first that $y^{s}=y^{* s}=0$ at full employment, by assumption. The equilibrium conditions in the domestic and foreign goods markets may therefore be written:

$$
\begin{aligned}
& 0=\delta q_{t}-\sigma r_{t}+g_{t}, \\
& 0=-\delta^{*} q_{t}-\sigma^{*}\left(r_{t}-{ }_{t} q_{t+1}+q_{t}\right)+g_{t}^{*} .
\end{aligned}
$$

Eliminating the domestic real interest rate $r_{t}$ from the above equations leads to the stochastic difference equation:

$$
{ }_{t} q_{t+1}=\left(\frac{\sigma \sigma^{*}+\delta \sigma^{*}+\delta^{*} \sigma}{\sigma \sigma^{*}}\right) q_{t}+\frac{g_{t}}{\sigma}-\frac{g_{t}^{*}}{\sigma^{*}} .
$$

This equation says that an exogenous increase in the demand for domestic products results in a higher relative domestic real interest rate given $q_{t}$, and so, in a higher expected value for $q_{t+1}$. A general solution is:

$$
\begin{aligned}
q_{t}= & \frac{1}{\sigma \sigma^{*}+\delta \sigma^{*}+\delta^{*} \sigma} \sum_{j=0}^{\infty}\left(\frac{\sigma \sigma^{*}}{\sigma \sigma^{*}+\delta \sigma^{*}+\delta^{*} \sigma}\right)^{j}\left(\sigma_{t} g_{t+j}^{*}-\sigma^{*}{ }_{t} g_{t+j}\right) \\
& +x_{t}\left(\frac{\sigma \sigma^{*}+\delta \sigma^{*}+\delta^{*} \sigma}{\sigma \sigma^{*}}\right)^{t},
\end{aligned}
$$

where $\left\{. \ldots, x_{t-1}, x_{t}, x_{t+1}, \ldots\right\}$ is any sequence of random variables with the martingale property:

$$
{ }_{t} x_{t+1}=x_{t} .
$$

The "fundamentals" solution, equation 6 , assumes that this sequence of random variables is the trivial process $x_{t}=0$, for all $t$, so that $q_{t}$ depends only on the expected future paths of aggregate demands. It is the assumption of this "transversality" condition that yields a unique solution for the model..$^{79}$ Equation 2 in the text follows from equation 6 if it is assumed that $g$ and $g^{*}$ are expected to be constant.

79. For theoretical arguments for imposing transversality conditions, see Obstfeld and Rogoff, "Speculative Hyperinflations"' and "Ruling Out Divergent Speculative Bubbles." For a discussion of solutions to stochastic difference equations, see Thomas J. Sargent, Macroeconomic Theory (Academic Press, 1979). Stochastic bubble solutions were proposed in Olivier J. Blanchard, "Speculative Bubbles, Crashes, and Rational Expectations," Economics Letters, vol. 3, no. 4 (1979), pp. 387-89. 
To find the full-employment equilibrium value of $p_{t}$, use the homeregion money market equilibrium to solve for the nominal interest rate $i_{t}$ $\left(=r_{t}+{ }_{t} p_{t+1}-p_{t}\right)$. When this solution is substituted into the first goodsmarket equilibrium condition in equation 13 , the result is the difference equation:

$$
{ }_{t} p_{t+1}=\left(\frac{1+\lambda}{\lambda}\right) p_{t}-\left(\frac{\delta}{\sigma}\right) q_{t}-\frac{g_{t}}{\sigma}-\frac{m_{t}}{\lambda} .
$$

Define $\omega=(1+\lambda) / \lambda$. A transversality condition similar to the one imposed in deriving equation 6 implies that the solution of the above difference equation is:

$$
p_{t}=\left(\frac{1}{\omega}\right) \sum_{j=0}^{\infty} \omega^{-j}\left[\left(\frac{\delta}{\sigma}\right){ }_{t} q_{t+j}+\frac{g_{t+j}}{\sigma}+\frac{{ }_{t} m_{t+j}}{\lambda}\right] .
$$

Define $\eta=\frac{\sigma \sigma^{*}+\delta \sigma^{*}+\delta^{*} \sigma}{\sigma \sigma^{*}}$. Evaluation of equation 14 requires simplification of the double sum:

$$
\begin{aligned}
& \sum_{j=0}^{\infty} \omega^{-j}{ }_{t} q_{t+j}= \\
& \sum_{j=0}^{\infty} \omega^{-j}\left[\frac{1}{\sigma \sigma^{*}+\delta \sigma^{*}+\delta^{*} \sigma} \sum_{h=j}^{\infty} \eta^{j-h}\left(\sigma_{t} g_{t+h}^{*}-\sigma^{*}{ }_{t} g_{t+h}\right)\right]
\end{aligned}
$$

(recall equation 6). To simplify the foregoing equation, rewrite it as:

$$
\begin{aligned}
\sum_{j=0}^{\infty} \omega^{-j}{ }_{t} q_{t+j} & =\left(\frac{1}{\eta}\right) \sum_{j=0}^{\infty}\left[\sum_{h=0}^{j} \omega^{-h} \eta^{h-j}\right]\left(\frac{{ }_{t} g_{t+j}^{*}}{\sigma^{*}}-\frac{{ }_{t} g_{t+j}}{\sigma}\right) . \\
& =\left(\frac{1}{\eta}\right) \sum_{j=0}^{\infty}\left(\frac{\omega^{-j-1}-\eta^{-j-1}}{\omega^{-1}-\eta^{-1}}\right)\left(\frac{{ }_{t} g_{t+j}^{*}}{\sigma^{*}}-\frac{t g_{t+j}}{\sigma}\right) .
\end{aligned}
$$

Substitute this into equation 14 to obtain the full-employment equilibrium price of the home region's output,

$$
\begin{aligned}
p_{t}= & \left(\frac{1}{\omega}\right) \sum_{j=0}^{\infty} \omega^{-j}\left(\frac{{ }_{t} m_{t+j}}{\lambda}+\frac{t g_{t+j}}{\sigma}\right) \\
& +\frac{\delta / \sigma}{\eta-\omega} \sum_{j=0}^{\infty}\left(\omega^{-j-1}-\eta^{-j-1}\right)\left(\frac{{ }_{t} g_{t+j}^{*}}{\sigma^{*}}-\frac{t g_{t+j}}{\sigma}\right) .
\end{aligned}
$$


Let $\omega^{*}=\frac{1+\lambda^{*}}{\lambda^{*}}$. A similar derivation leads to the full-employment equilibrium foreign price,

$$
\begin{aligned}
p_{t}^{*}= & \left(\frac{1}{\omega^{*}}\right) \sum_{j=0}^{\infty} \omega^{*-j}\left(\frac{{ }_{t} m_{t+j}^{*}}{\lambda^{*}}+\frac{t g_{t+j}^{*}}{\sigma^{*}}\right) \\
& -\frac{\delta^{*} / \sigma^{*}}{\eta-\omega^{*}} \sum_{j=0}^{\infty}\left(\omega^{*-j-1}-\eta^{-j-1}\right)\left(\frac{{ }_{t} g_{t+j}^{*}}{\sigma^{*}}-\frac{{ }_{t} g_{t+j}}{\sigma}\right) .
\end{aligned}
$$

The equilibrium nominal exchange rate, $e_{t}=q_{t}+p_{t}-p_{t}^{*}$, is given by equations 6,15 , and 16 .

Equations 3, 4, and 5 in the text follow from equations 15, 16, and 6 under the assumptions that no changes in $g$ or $g^{*}$ are expected and that money supplies are expected to grow forever at rates $\mu$ and $\mu^{*}$. Equation 1 can then be derived from the money demand functions, the definition of the real interest rate, and the observation that $p$ and $p^{*}$ rise at rates $\mu$ and $\mu^{*}$ in full-employment equilibrium when no changes in monetary growth rates are expected.

\section{Analyzing Short-Run Macroeconomic Interactions}

A diagrammatic depiction of the world economy's short-run equilibrium is given in figure $6 .{ }^{80}$ For given domestic and foreign nominal wages, the locus labeled $\mathrm{HH}$ shows the combinations of domestic and foreign price levels that clear the domestic goods market when world asset markets are in equilibrium. An increase in $p$ works through both relativeprice and interest rate effects to cause an excess supply of domestic goods, while an increase in $p^{*}$ restores goods-market balance by switching world demand toward domestic goods and increasing foreign output. $H H$ therefore slopes upward, as drawn. The $F F$ locus, along which the foreign goods market clears when world asset markets are in equilibrium, has a positive slope for the same reason.

More formally, the $H H$ schedule is obtained by equating aggregate demand and supply in the domestic goods market, eliminating the current

80. The diagram will be recognized as a direct descendant of the one developed in Romney Robinson, "A Graphical Analysis of the Foreign Trade Multiplier," Economic Journal, vol. 62 (September 1952), pp. 546-64. 
Figure 6. World Economy's Short-Run Equilibrium

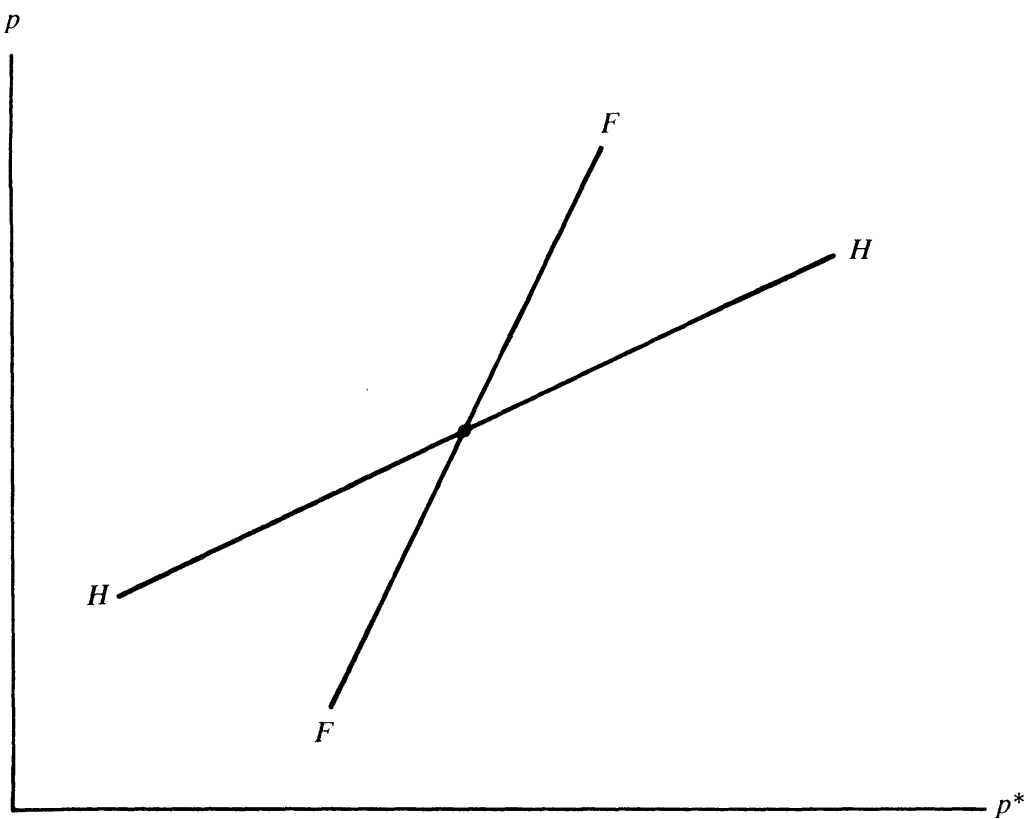

exchange rate through use of the nominal interest parity condition, eliminating the domestic and foreign nominal interest rates through use of the corresponding money-market equilibrium conditions, and eliminating national outputs through use of the aggregate supply functions. The resulting equilibrium condition is:

$$
\begin{aligned}
H H: & \left(\theta+\frac{(\sigma+\delta)(1+\lambda+\phi \theta)}{\lambda}\right) p_{t} \\
& -\left(\delta+\gamma \theta^{*}+\delta \frac{\left(1+\phi^{*} \theta^{*}\right)}{\lambda^{*}}\right) p_{t}^{*}=\delta_{t} e_{t+1} \\
& +\sigma_{t} p_{t+1}+\theta\left(1+\frac{(\sigma+\delta) \phi}{\lambda}\right)_{t-1} p_{t}-\theta^{*}\left(\gamma+\frac{\delta \phi^{*}}{\lambda^{*}}\right)_{t-1} p_{t}^{*}+g_{t} \\
& +\frac{(\sigma+\delta) m_{t}}{\lambda}-\frac{\delta m_{t}^{*}}{\lambda^{*}} .
\end{aligned}
$$


An analogous procedure leads to the $F F$ schedule:

$$
\begin{aligned}
F F: & \left(\theta^{*}+\frac{\left(\sigma^{*}+\delta^{*}\right)\left(1+\lambda^{*}+\phi^{*} \theta^{*}\right)}{\lambda^{*}}\right) p_{t}^{*} \\
& -\left(\delta^{*}+\gamma^{*} \theta+\frac{\delta^{*}(1+\phi \theta)}{\lambda}\right) p_{t}=-\delta^{*}{ }_{t} e_{t+1} \\
& +\sigma_{t}^{*} p_{t+1}^{*}+\theta^{*}\left(1+\frac{\left(\sigma^{*}+\delta^{*}\right) \phi^{*}}{\lambda^{*}}\right)_{t-1} p_{t}^{*}-\theta\left(\gamma^{*}+\frac{\delta^{*} \phi}{\lambda}\right)_{t-1} p_{t} \\
& +g_{t}^{*}+\frac{\left(\sigma^{*}+\delta^{*}\right) m_{t}^{*}}{\lambda^{*}}-\frac{\delta^{*} m_{t}}{\lambda} .
\end{aligned}
$$

Expectations as of time $t-1$ are predetermined, while the effect of shocks on currently expected future values of $e, p$, and $p^{*}$ can be determined from equations 6,15 , and 16 .

Under the assumption that the structural coefficients in the two countries are similar, $F F$ is steeper than $H H$. The intersection of the schedules determines short-run equilibrium output prices, and, by implication, output levels, the exchange rate, and interest rates.

Consider next the two policy actions discussed in the text, a deceleration of home monetary growth and a home fiscal expansion.

A permanent, unanticipated reduction in $\mu$ operates through two separate channels to shift the $H H$ locus. Equation 3 implies that the fullemployment price level, which is expected to prevail once wages have adjusted to the shock in the following period, falls. Equation 5 implies that the expected future exchange rate also falls. The first effect raises the real interest rate at any point on $H H$ by lowering the expected inflation rate, while the second effect causes the spot exchange rate to fall at any point on $H H$. As both effects lower aggregate demand, the new goods-market equilibrium locus lies below $H H$, at $H^{\prime} H^{\prime}$, as shown in figure 7.

$F F$ is also affected by the fall in $\mu$. Because the expected future value of the exchange rate $e$ falls, the spot value of $e$ also falls at any point along $F F$, shifting world demand toward foreign goods and generating excess demand along that schedule. It follows that the new equilibrium locus for the foreign goods market lies below $F F$, at $F^{\prime} F^{\prime}$. The intersec- 
Figure 7. Permanent Fall in Home Money Growth

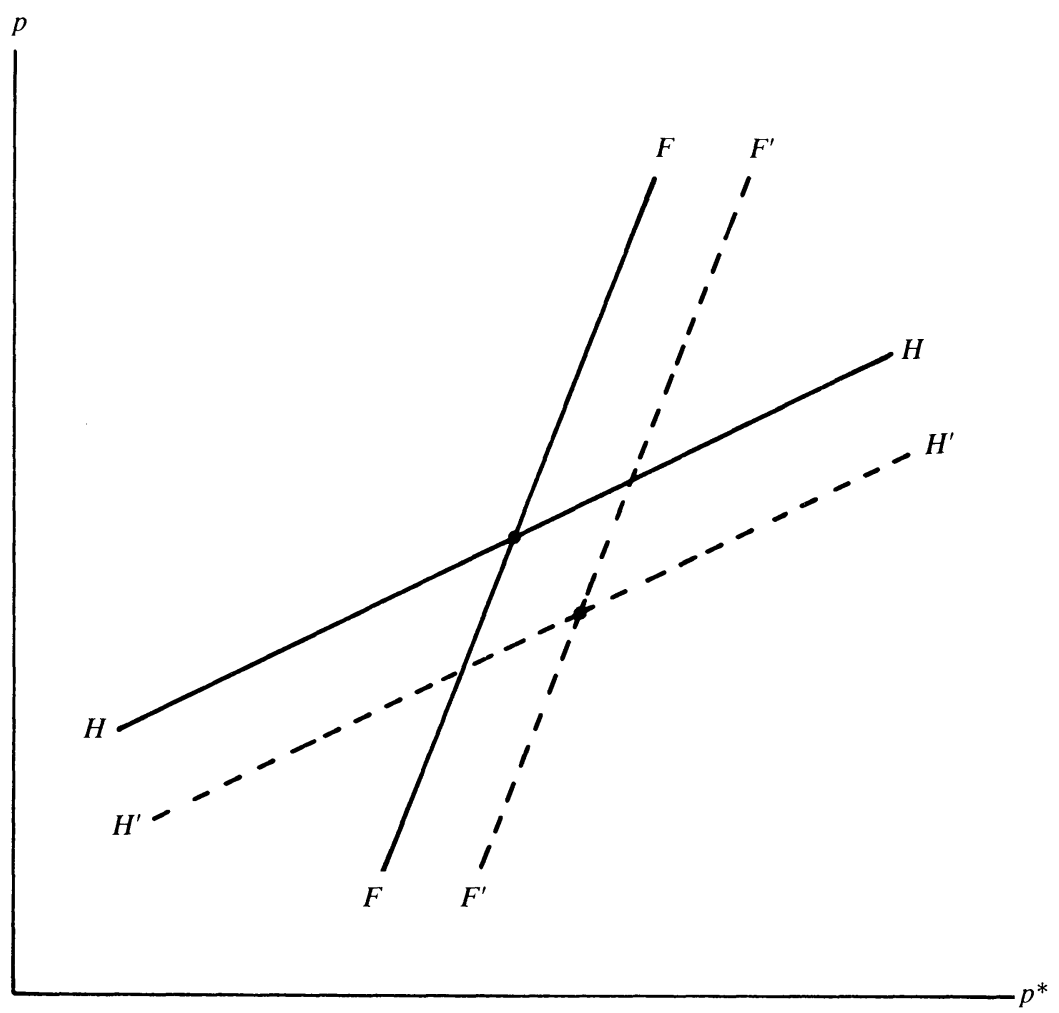

tion of $H^{\prime} H^{\prime}$ and $F^{\prime} F^{\prime}$ indicates a lower domestic price level, but shows that the effect of domestic disinflation on the foreign price level is theoretically ambiguous. The condition for $p^{*}$ to rise is $\gamma^{*}<\delta^{*} /(\sigma+\delta)$. Since $\gamma^{*}$ is likely to be quite small, a domestic monetary crunch, while causing a recession at home, is presumed to stimulate output abroad in the short run.

A permanent, unanticipated fiscal expansion at home is represented by a rise in $g$. At any point along $H H$ there is now excess demand for domestic output, so $H H$ must shift upward to $H^{\prime} H^{\prime}$, as shown in figure 8. There is also an effect on the foreign goods market. At any point on $F F$, the real interest rate is now lower because the expected future price 
Figure 8. Permanent Home Fiscal Expansion

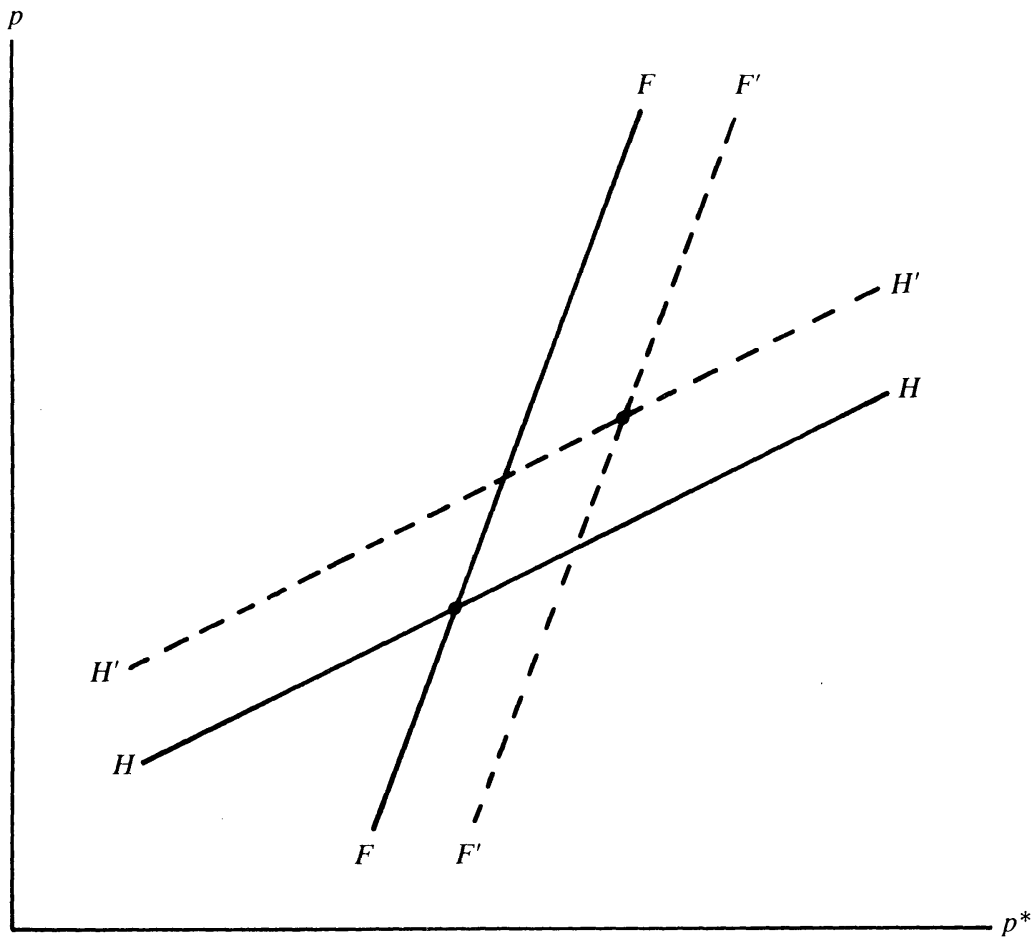

level is higher, and the terms of trade have deteriorated. Both developments point to excess demand for foreign output, so $F F$ must shift downward to $F^{\prime} F^{\prime}$. The result of fiscal expansion at home is thus a simultaneous rise in output and prices in both regions. 


\section{Comments and Discussion}

Richard N. Cooper: Maurice Obstfeld has given us a superb survey and synthesis, and in some respects an extension, of the current state of exchange rate theory and of open economy macroeconomics under flexible rates. I predict that it will end up on many graduate reading lists.

I want first to make four somewhat technical comments on the paper, then comment on Obstfeld's remarks on intervention, and then conclude with two observations on the more general policy issues that he raises at the end of his paper.

First, I have deep reservations about the standard money demand equation that Obstfeld, following most macroeconomists, uses. The only point I would make here is that the argument in the equation is income and output, not expenditure. The model deals with small changes, and it is interesting to note that in the United States, which has not been thought of as an open economy, while income rose 13 percent in real terms over the last ten quarters, expenditures rose 17 percent in real terms. That is a consequential difference. With expenditure rather than income in the U.S. money demand equation, there would be higher pressure on interest rates, greater appreciation of the currency, and more downward pressure on the price level than the argument in the equation implies. The change would probably have only quantitative, not qualitative, results. But theoretically it could alter the signs of the impact of a given exogenous disturbance, as Kenneth Weiller, a graduate student at Harvard, has shown. For instance, tax reduction could lead to a decline in domestic output and prices if imports are greatly stimulated and demand for money depends on expenditure. Weiller has also shown that output performs less well in money demand equations (as measured by the stability of velocity and by the standard error of estimate) for 
most major industrial countries than does either consumption or total expenditure. So I urge all those who are dealing with empirical questions involving the demand for money to think more seriously about what the equation really means in an open economy, and how we justify it.

My second point has to do with the influence of expectations about future budget deficits on the current exchange rates. That is captured in Obstfeld's equation 6, which implies a stability over time of the underlying structural coefficients, certainty of view about the stability of those coefficients, and certainty about the future path of budget deficits.

While the influence of the distant future diminishes in this equation because a coefficient less than unity gets compounded over time, its rate of fading is determined entirely by the structural coefficients. I would think that, in reality, confidence about the future of the economy fades quite rapidly as "the future" becomes a more distant time. There is an increasing cone of uncertainty about structural coefficients as one projects events further into the future, so that a subjective uncertainty discount should be applied to this equation and, indeed, to any forwardlooking equation. I would suggest further that uncertainty about the future is so great that expected events as far ahead as, say, five years have negligible influence on the current exchange rate, which is what equation 6 determines.

Third, the portfolio balance framework that is used here, along with the assumption of high asset substitutability, which is now a very widely used framework for analyzing open economy macroeconomics, leads to the a priori finding that an increase in either present or future government spending, holding money constant, necessarily leads to an appreciation of the currency; and under rational expectations the currency will appreciate at once. Increase your expectation about any future government spending, and immediately the value of the currency goes up.

It is always nice when a theoretical model gets a well-defined result; we have so many ambiguous results these days. But we have to ask whether this result is really a verity, or whether it is merely an artifact of this particular model construction. It is noteworthy that the Japanese Economic Planning Agency (EPA) model of the world economy gets this result for the United States and Canada, but not for the other leading industrial countries, where an increase in either actual or expected future government spending leads to a depreciation rather than an appreciation of the currency. The mediating reason is that an increase in government 
spending in these countries has a much smaller impact on domestic interest rates than is the case for the United States or Canada. It is difficult in these complex, several-hundred-equation models to know exactly what is going on, but I do not think that the EPA result should be rejected on a priori grounds. On the contrary, it corresponds to experience as best EPA has been able to estimate it.

Similarly, I would ask whether we should be certain that a reduction in either the actual or future U.S. budget deficit would weaken the dollar the next day. I am not certain. If the executive branch and the Congress struck a consequential deal to reduce budget deficits a year or two from now, I would not be at all surprised to see an immediate appreciation of the dollar rather than a depreciation. Yet that could not happen in Obstfeld's model, or indeed in most of the models of exchange rate determination that are used these days.

Fourth, in comparing a flexible exchange rate with a fixed exchange rate system, Obstfeld suggests that Europe has been better off in recent years because of the stimulus provided to its exports by the appreciation of the dollar, which putatively came from the expansionary U.S. fiscal policy. It might be so, and I have similarly argued that the Europeans are better off than they think they are, on these grounds.

But the comparison Obstfeld makes in this regard is with a hypothetical world of fixed exchange rates. One of the troubling features of Europe today is the weakness of investment in plant and equipment, even in the presence of a vigorous export growth. As empirical social scientists, economists should ask why that is so. One possible explanation is that European businessmen do not believe that the current exchange rates are sufficiently enduring to warrant investment on the basis of the strong orders that they are currently getting from overseas.

That possibility raises the hypothesis that real exchange rate uncertainty may have a strongly inhibitory effect on investment, not only in countries that now have strong export orders, such as Europe, but even in countries where the export orders are weak, such as the United States, where businessmen hesitate to invest on the prospect of a future depreciation in the dollar.

So it could be that real exchange rate uncertainty arising from the fluctuations that we have seen in recent years inhibits investment everywhere. Certainly American businessmen say now that they face agonizing decisions about whether to locate their next major plant 
expansion here or in some other country, and many of them are stymied on that decision. Obstfeld's model does not capture even the possibility of an effect of uncertainty on investment decisions.

On the matter of intervention, Obstfeld asserts that all evidence suggests that sterilized exchange rate intervention does not work. I do not think that such a strong statement is warranted. The evidence is, in fact, quite ambiguous; the tests are weak; they apply mainly to the influence of asset composition on the exchange risk premium rather than to sterilized intervention as such; and they often assume rational expectations, which may be what the tests are really rejecting. I mention this point because the "noneffectiveness of sterilized intervention" seems to have become the conventional wisdom among monetary economists.

Now I turn to two more general questions that are raised in the latter part of Obstfeld's paper. One is the contention that policy actions to restrict free movements of capital would reduce efficiency and welfare. Some economists have gone so far as to draw a parallel between capital restrictions and restrictions on trade, suggesting that both are equally undesirable. I cannot think of an area in which the unqualified application of general theoretical propositions is more misleading to policy decisions than this one.

It is a very complicated issue, and on this occasion I can only suggest a few reservations. First, it is well known that overseas investments undertaken in order to get behind a tariff wall are in general welfarereducing from a world point of view. It is a general proposition from second-best theory that an impediment at one place in the system, combined with freedom in another, can reduce welfare rather than increase it.

Second, at the much more empirical level, it is well known that many capital movements by or on behalf of households, especially in Europe, are just tax evasions, nothing more, nothing less. Investors are attracted to overseas investments in order to evade domestic taxes.

Tax evasion raises a complicated question. Is it welfare-reducing or not? That depends on precisely how we specify the social welfare function, and in particular, on how we put public goods into the welfare function, and hence the financing of those public goods.

When Mexico borrowed heavily abroad in 1980-82, with freedom of capital movements and an overvalued currency that encouraged much capital export by Mexicans, including some of the officials involved in 
determining Mexican policy, was that welfare-enhancing or not? When a democratically elected government of France in 1981 did, mistakenly in my view, exactly what it said it was going to do during the campaign despite the objections of the wealthy minority, there was a large outflow of capital from France. In what sense was that a welfare-enhancing movement of capital?

To come closer to home, the United States now has an unprecedentedly large net inflow of capital, over two and a half percent of GNP. Does this reflect a sudden increase in time preference on the part of Americans? On revealed preference grounds, yes. Relative to the recent past, Americans apparently want to consume now, pay later. The large inflow from abroad helps satisfy that desire.

On close inspection, however, the consumption is public rather than private, for the most part. And we are having a great public debate over both the size and the character of the public sector, and in particular over the mix between nondefense and defense spending. While the debate is taking place, we are borrowing in order to avoid making a decision. On still closer inspection, I would suggest that what we are seeing is not a reasoned debate at all, but a game of chicken, a contest over who will back down first-the president or the Democrats in the House of Representatives.

In the meantime, the United States last year drew in $\$ 100$ billion worth of capital from the rest of the world; it will probably be $\$ 120$ billion this year, and on plausible projections perhaps $\$ 150$ billion next year. Now is this what we mean by an efficient allocation of the world's capital? I would modestly suggest that economists should take another look at this question of whether impediments to capital flows, as they actually take place in the world, in fact are welfare-reducing.

So as not to leave a misleading impression, I will say explicitly that I do not favor the imposition of capital controls; but my reasons do not stem from the fact that I think they would be directly welfare-reducing. Rather, it would be administratively extremely complicated to control capital movements effectively, and to do so for longer than a few years would probably require controls over certain forms of trade as well. My point is that we should avoid uncritical application of general theoretical principles to the actual state of affairs.

Finally, on the nature of the exchange rate regime, Obstfeld reaches the now widely accepted conclusion that while under certain circum- 
stances a fixed exchange rate regime would be superior to a flexible exchange rate regime, that is not generally the case.

Furthermore, he argues that in order to get most of its benefits, the rates in a fixed exchange rate regime have to be credibly fixed; but that is not possible because there will always be a suspicion that sooner or later the exchange rate will be moved. One way to deal with this credibility problem is to eliminate exchange rates, and the way to eliminate the exchange rates is to eliminate different currencies and move to one currency. I will not develop that thought at length here. But I put forward what many will regard as a quixotic proposal in Foreign Affairs last fall, set far enough in the future, the year 2010 , so as not to be immediately alarming, for the creation of a single currency-not one world currency, which I think is neither attainable nor desirable, but one currency among the industrialized democracies.

That proposal deals explicitly with a politically vital point on which Obstfeld touches; namely the balance to be struck between discipline and autonomy. I will not argue the case here, but what leads me in this direction is the judgment that large changes in real exchange rates of the type that we have seen in recent years, driven mainly by capital movements, will become intolerable to the business community. The consequence in the absence of some constructive thought about where we want to go will be greater restrictions, both on trade and on capital movements, in order to reduce the exchange rate uncertainties, which from the point of view of any individual economic agent are completely arbitrary. If we want to avoid that outcome, we need to think more boldly about the future of the monetary system.

Paul R. Krugman: A dozen years after the abandonment of fixed exchange rates, it is clear that the system of flexible rates is a big disappointment. But life since 1973 has in general been nothing but a series of disappointments. In his paper Maurice Obstfeld argues that while floating rates have not fulfilled any of the expectations of their advocates, fixed rates would have been even worse. His argument is clear and well conceived, and I almost believe it. What I want to do in my comment is to offer a brief summary of his argument, offer an additional argument in support of floating rates, then present some criticism. 
After reviewing the macroeconomic and exchange rate developments of recent years, the paper sets out a theoretical model within which to interpret these developments. The model is constructed with consummate craftsmanship. As a practitioner myself, I was delighted with the way that Obstfeld finessed his way past awkward technical issues (though I would dearly love to know how long a "period" is). Despite the sophistication of the framework, however, the model still works pretty much like the old Mundell-Fleming model. The key result remains the same: a move from fixed to floating rates affects monetary and fiscal policy in opposite ways. Shifts in demand that originate in the $I S$ curve, which Obstfeld somewhat misleadingly calls shifts in aggregate demand, affect domestic output less under flexible rates than they do under fixed rates. Shifts in demand that originate in the $L M$ curve, by contrast, affect domestic output more under flexible than under fixed rates.

Obstfeld points out that this result can be used to analyze the stabilizing properties of alternative exchange rate regimes, along the lines of the familiar Poole analysis of interest rate versus money targets. If shocks originate largely in the $I S$ curve, flexible rates will be more stabilizing than will fixed rates. If they originate largely in the $L M$ curve, fixed rates will be more stabilizing than flexible rates.

Finally, Obstfeld presents evidence that, at least over the past few years, $I S$-type shocks have been important and perhaps dominant in exchange rate movements. The evidence is partly the direct observation of divergent fiscal trends, partly the demonstration that stock market prices and exchange rates have not moved together the way one would expect if the shocks were monetary in origin. The conclusion is that we seem to be living in the kind of world where flexible rates are better than fixed rates.

The first comment I would like to add is that there is another powerful argument for exchange rate flexibility that is apparent in Obstfeld's data, though not in his text. This is the fact that even with internationally coordinated monetary and fiscal policies, equilibrium real exchange rates will not be constant over time, because of structural change. Consider Obstfeld's figure 1. The real appreciation of the dollar since 1979 has only brought it back to roughly its 1970 level; yet a real exchange rate that in 1970 was associated with a current account surplus is now associated with a massive current account deficit. The natural conclusion is that the real dollar exchange rate associated with a balanced current 
account has been depreciating steadily over this period. Structural change of this kind appears to occur even faster if we consider the converse case of Japan, which has moved into massive current account surplus despite a real currency appreciation since 1980 .

These developments are not all that puzzling; it is not hard to rationalize them on the basis of a model in which the United States is a technological leader being overtaken by competitors. The point is, however, that if structural change requires substantial changes in real exchange rates, it will be easier to manage these if there are no fixed nominal parities to defend. I would argue that structural change rather than divergent monetary policies was the fundamental cause of the collapse of fixed rates at the beginning of the 1970s, and that any attempt to restore fixed rates would again face substantial stress from this direction.

Having introduced this argument in support of floating rates, I now offer an argument against them that I do not feel gets enough attention in Obstfeld's paper. This is the old view that floating rates expose the international system to the effects of destabilizing speculation. With the rise of efficient markets theory most economists came to discount this possibility, believing instead that asset prices would reflect current and expected future fundamentals. As Obstfeld documents, however, accumulating evidence has not supported this sanguine view. While it is always possible to rationalize the negative results by positing large and shifting risk premiums, there is in fact not a shred of positive evidence for the assumption that exchange markets, or for that matter, bond and stock markets, efficiently use information the way that theoretical models suppose.

The key and dramatic piece of evidence is that interest differentials have consistently mispredicted the direction of exchange rate change since 1980. This could represent a "peso problem," but as Jeffrey Frankel has shown (BPEA, 1:1985), the errors have been too large and persistent to be explained in this way. (Frankel actually set out to test for the possibility of a "rational bubble,', but, as Obstfeld notes, such bubbles and peso problems are observationally equivalent, so Frankel's test allows us to reject both.) The market has been purely and simply getting it wrong.

My complaint is that Obstfeld's paper does not take this evidence seriously enough. The discussion of destabilizing speculation is limited 
to the possibility of "rational" "bubbles, which is already a more favorable assumption about the market than the data allow. And the whole discussion is confined to the issue of volatility, reflecting an implicit assumption that large and sustained exchange rate misalignments cannot be explained by malfunctioning financial markets. This need not be the case; various people, including myself, have argued that an important part of the dollar's current strength reflects an expectational error on the part of the exchange market. Whatever one thinks of this view, the point is that autonomous exchange speculation, like $L M$ shocks, is more destabilizing under flexible than under fixed rates. If destabilizing speculation is at all important-and the evidence does not allow us to dismiss this possibility-then this is an argument against the current system.

Finally, I turn to the crucial issue: would greater fixity of rates have helped avoid the current mess in the international economy? Like all good men, Obstfeld attributes the mess essentially to the divergence in fiscal policy between the United States and other industrial countries. $\mathrm{He}$ argues convincingly that the consequences of that divergence would have been no better and probably worse under fixed rates. He also argues, less convincingly, that fixed rates would not have disciplined the U.S. government. I am not so sure. If rates had been fixed, the fiscal deficit would have presented the Federal Reserve with an agonizing choice: accommodate the deficit and risk reigniting inflation, or tighten money and provoke a worldwide reserve crisis. Perhaps so stark an alternative would have forced the Reagan administration to be more responsible.

The fact is that the script we have actually followed is beginning to look more and more like a tragedy. The long awaited wave of protectionism generated by the strong dollar is now breaking over our heads, and the international trading system may not have much time left. It is hard not to wish that we had tried something different.

\section{General Discussion}

Several participants commented on whether domestic fiscal expansion necessarily leads to domestic currency appreciation under a floating rate system, as the theory developed in Maurice Obstfeld's paper suggests it 
should. In his formal comments, Richard Cooper had noted that the Japanese Economic Planning Agency's (EPA) macroeconomic model implied the reverse for Japan and several other industrialized countries. Lawrence Krause mentioned recent work by Jeffrey Sachs that traced the result for Japan to the weak linkages in the Japanese economy between fiscal expansion and interest rates and between interest rates and investment inflows from abroad. Sachs attributed these weak linkages to the historical presence of capital controls in Japan; since these capital controls have now been abandoned, the relationship between fiscal policy and the value of the yen against other currencies would very likely look different today. William Branson suggested that the EPA result for Japan in part reflects the maintained assumption of low substitutability between assets, so that foreigners' demand for Japanese debt is insensitive to Japanese interest rates. In contrast to the Japanese model, the Canadian RDX-2 model yields a neutral prediction concerning the effect of domestic fiscal expansion on the value of the domestic currency, and U.S. models typically yield predictions like those in Obstfeld's analysis. Paul Krugman questioned whether it was meaningful to ask about the effect of a change in fiscal policy on the exchange rate assuming monetary policy fixed. In his view, a more meaningful thought experiment would ask what a shift in the fiscalmonetary policy mix that left GNP unchanged would do to the exchange rate; the conclusion that expansionary fiscal policy leads to a real appreciation is much more robust if one imagines it to be accompanied by a "leaning against the wind" change in monetary policy.

Branson pointed to Obstfeld's equation 9, noting its implication that the changes in U.S. fiscal policy over the past few years should have produced a much smaller appreciation of the dollar than has actually occurred. However, that equation is based on long-run elasticities of demand with respect to the real exchange rate. Taking a short-run perspective, if each 1 percent increase in the real exchange rate adds roughly $\$ 2.5$ billion to the current account deficit, as work by both Robert Lawrence and Stephen Marris suggests, one would need something like a 50 percent real appreciation to finance $\$ 125$ billion of the budget deficit by running a current account deficit. Branson suggested that the appreciation of the dollar over the past few years is perhaps less surprising when viewed in this light.

A good deal of discussion focused on whether the world economy has 
fared better under floating rates than it would have under fixed rates. One relevant issue is whether the source of shocks to the system has been primarily the goods market or the asset market. Lawrence criticized Obstfeld's interpretation of the positive correlation between stock price changes and exchange rate changes as evidence for the dominance of goods-market shocks rather than asset-market shocks, noting that this interpretation follows only in the case of purely domestic disturbances. If, for example, foreigners decided to switch into U.S. assets, there would be both an increase in U.S. stock prices and an appreciation of the U.S. dollar. Obstfeld replied that the positive correlation between European and U.S. stock price changes documented in the paper weighs against the view that shifts from European to American assets have been the dominant sort of shock in recent years. Marris stressed the importance of exogenous shifts in investment-savings behavior in the private sector. The weakness of investment relative to the supply of private savings outside the United States was probably as important to the rise in the dollar as the reduction in high-employment budget deficits was.

Marris argued that it is misleading to compare flexible rates with rigidly fixed rates. "Fixed" rates would always have to be changed, the only question being when and how. Thus the real choice is between unmanaged flexible rates and some form of managed flexible or adjustable rates. The right question to ask, Marris continued, is the extent to which the actual operation of any particular exchange rate regime provides an anchor for exchange rate expectations. Noting that the United Kingdom has floating rates, while France is part of the European Monetary System (EMS), he reasoned that it is likely that the United Kingdom has had to deviate more from its domestic monetary objectives than has France, because the market does not have a good sense of the British government's intention with regard to exchange rates. Based on his reading of experience, Marris concluded that a credible managed floating or adjustable fixed rate involves less subordination of monetary policy to exchange rate objectives than does the sort of wildly fluctuating flexible rate regime we have experienced. John Williamson was also disappointed that the paper's comparison of alternative regimes was limited to floating rates versus Bretton Woods fixed rates. He pointed to a target range system as an alternative worth discussing.

Several participants disagreed with Obstfeld's conclusion that a fixed rate system would not have imposed any greater fiscal discipline on the 
United States than has the existing floating rate system. Lawrence echoed Krugman's view, expressed in his formal comments, that a fixed rate system would at least have made the choices facing the United States much starker. Price levels would have had to rise roughly 40 percent more in the United States than abroad to achieve the real result produced under the floating rate system; Lawrence believes this would not have been politically feasible, so that a fixed rate system could not have accommodated fiscal policy of the sort the United States has actually pursued. Marris reasoned that the U.S. demand expansion would have been much more bottled up inside the United States with fixed rates than it was with flexible rates, and that this would have created greater pressures for change in both U.S. and European policy. Krugman argued that even a verbal commitment by policymakers to fixed exchange rates could be helpful, insofar as such a commitment would make it harder for them to deny that their actions were linked to what happened in foreign exchange markets. Franco Modigliani stressed that it was not correct to think of the United States as simply being above the law under a fixed rate system. In the early 1960 s, U.S. fiscal policy was to a significant extent dictated by the notion that U.S. interest rates could not be below those in the rest of the world. Lawrence suggested that fixed rates would more effectively impose discipline on the United States if the dollar were not the reserve currency. Williamson agreed that a reserve currency system was not an optimal system, in that it imposed no discipline on the reserve currency country. Obstfeld doubted that a fixed exchange rate would have promoted a more restrictive U.S. fiscal policy through its eventual price level effects; given outflows of reserves, the Europeans might well have devalued. The whole discussion of whether fixed rates would be more effective than flexible rates in imposing discipline on the United States puzzled Branson; if the United States were unhappy with outcomes under a particular regime, he reasoned, it could push for the regime to be altered.

Lawrence argued that any assessment of the relative merits of flexible and fixed exchange rates needs to look at investment flows as well as trade flows. If domestic monetary disturbances were large, a flexible exchange rate system could produce larger swings in the demand for domestic manufacturing output than would occur under a fixed rate system; a monetary contraction would cause the domestic currency to appreciate and thus add foreign demand cutbacks to domestic demand 
cutbacks. It is thus plausible, Lawrence concluded, that manufacturing investment could be relatively less attractive under a flexible rate regime than under a fixed rate regime.

Martin Baily expressed concern about the potential destabilizing consequences of a flexible rate regime. Under a fixed rate system, structural changes could be accommodated by differential growth rates in prices or wages that would occur relatively slowly and not require massive dislocation. Under a flexible rate system, strange policy mixes or speculation can cause large short-term movements in exchange rates, which then translate into large changes in resource allocation. No one would advise a manager of a business to base investment decisions on day-to-day changes in his or her firm's stock prices, Baily reasoned; in the same way, it does not make sense for resources to be allocated on the basis of day-to-day changes in exchange rates. Yet, to some extent this will occur; in a competitive world market, exchange rate signals cannot be ignored. Lawrence Summers amplified this point, noting that a large part of the variance in exchange rates cannot be explained by any of the factors econometricians have included in their models and thus appears to be random variation relative to economic fundamentals; he observed that it would not be efficient for firms' decisions to be driven by these seemingly random variations.

Robert Solomon questioned Cooper's idea that uncertainty about future exchange rates under the flexible rate regime has inhibited European investment. Tight fiscal policy in Europe has dampened investment there; moreover, European trade with the United States amounts to only a small share of total European output, so that a better competitive position vis-à-vis U.S. producers should not necessarily be expected to translate into a large increase in investment. Cooper responded that the volume of European trade in competition with U.S. produced goods, not European trade with the United States directly, was the relevant thing to look at in this context. Jeffrey Frankel reported that he knew of at least three studies providing evidence that exchange rate uncertainty affects trade flows. One reply to such concerns is that exchange rate uncertainty can always be hedged on forward exchange markets. But, Frankel noted, although the forward exchange market has grown substantially since fixed rates were abandoned, the cost of hedging as measured by the bid-ask spread has widened.

William Nordhaus argued that one cannot choose between flexible 
and fixed exchange rates on theoretical grounds. First, the nature of the shocks to the system may change over time. Second, asset market behavior is very poorly understood, which makes it difficult to predict the consequences of different sorts of shocks under different regimes. Third, Robert Lucas's critique that changes in regime may lead to changes in behavior rules seems particularly applicable to the choice of exchange rate regime. Nordhaus suggested that a more pragmatic assessment might be made by studying real-world experiments with alternative regimes, in particular the experience under the EMS. A careful study by Ken Rogoff suggests that the EMS did reduce the month-to-month volatility in nominal exchange rates, but not the magnitude of longer term swings in real exchange rates. Nordhaus's inspection of performance under the EMS did not lead him to believe that the United States should emulate the EMS model.

Ralph Bryant expressed his concern that too much may be expected from the choice of exchange rate regime. Given that national economies are interdependent and national governments operate autonomously, there is bound to be trouble at times no matter what the exchange rate regime. 